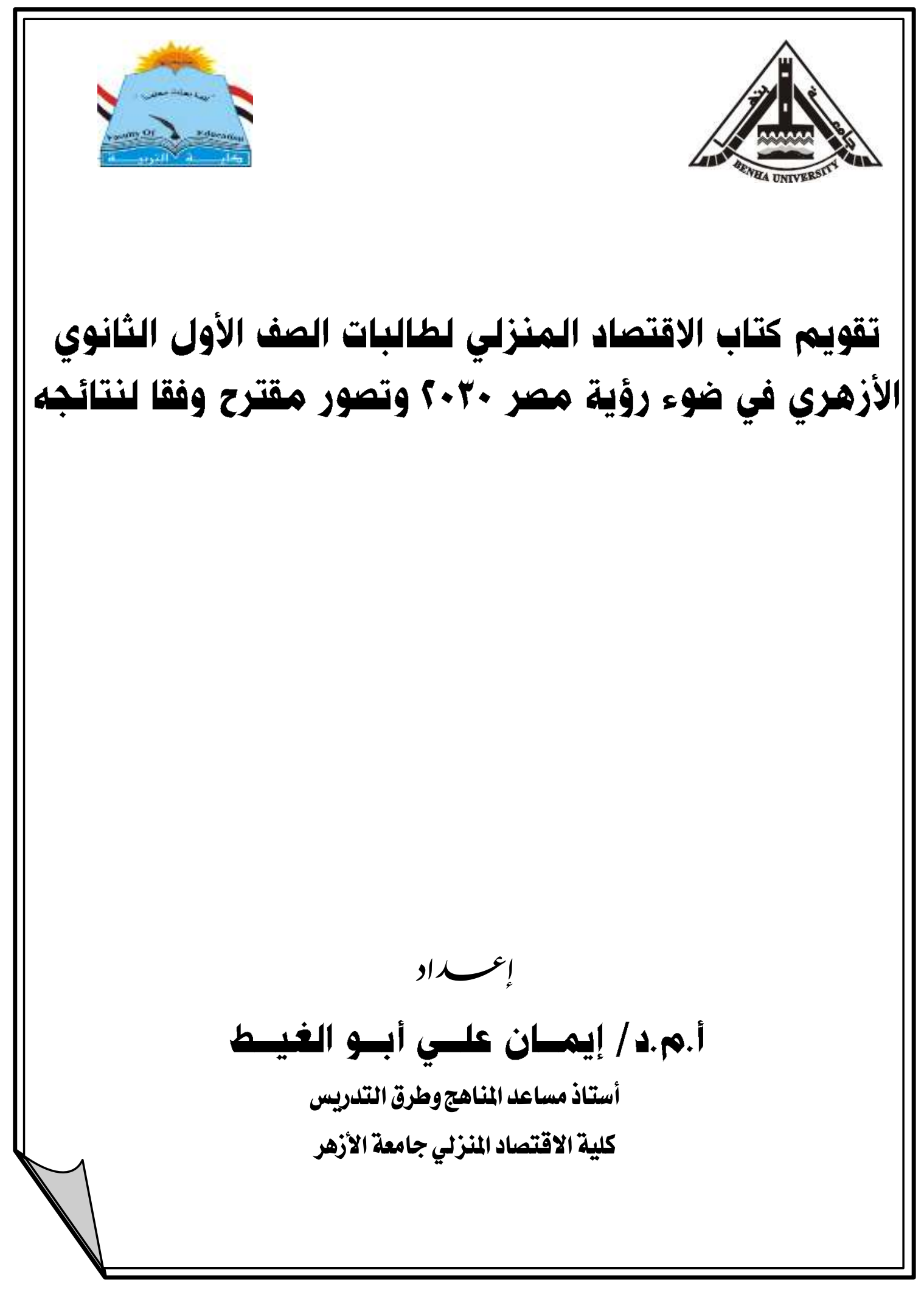




\title{
تقويم كتاب الاقتصاد المنزلي لطالبات الصف الأول الثانوي الأزهري في ضوء رؤية مصر •+r+r وتصور مقترح وفقا لنتائجه
}

\author{
! إنـإ
}

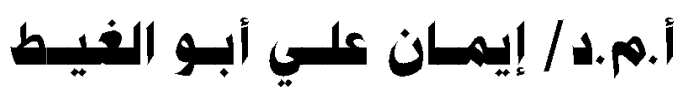

أستاذ مساعد المناهج وطرق التلدريس الإن الإني

كلية الاقتصاد المنزلي جامعة الأزهر

\section{ملذئم البدبث}

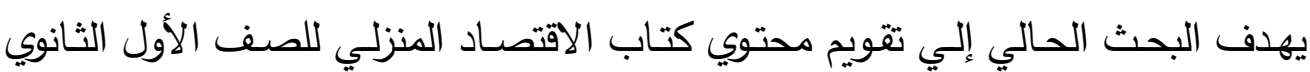

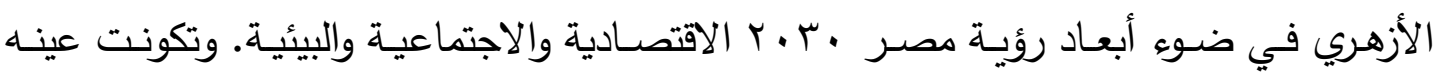

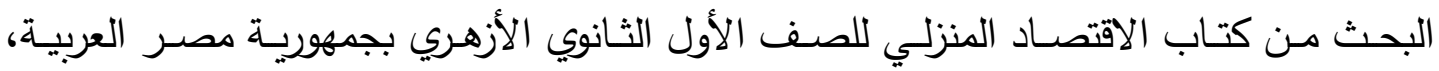

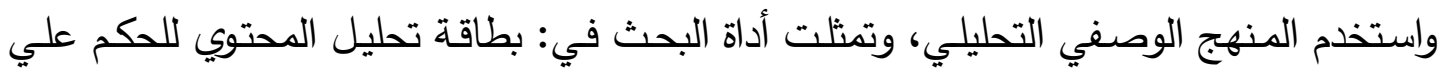

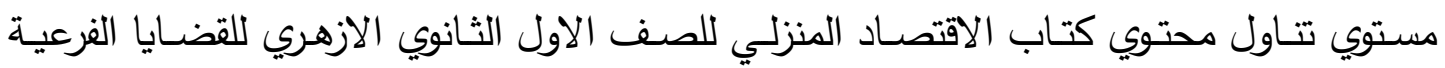

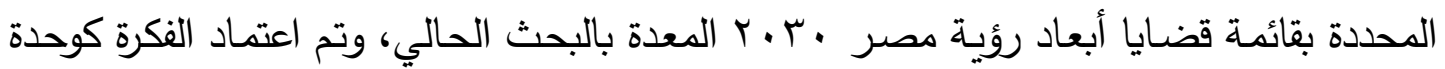

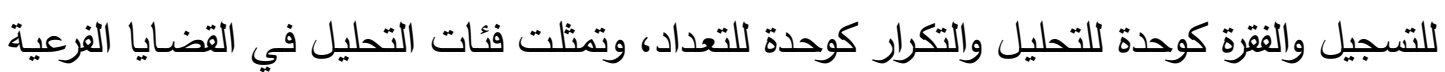

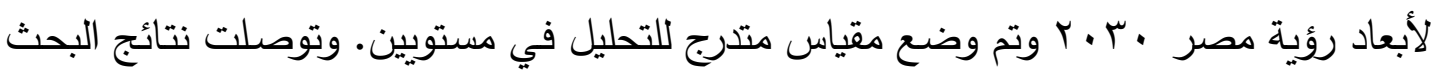

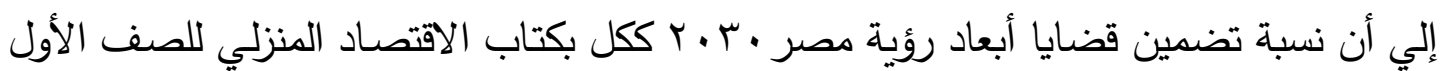

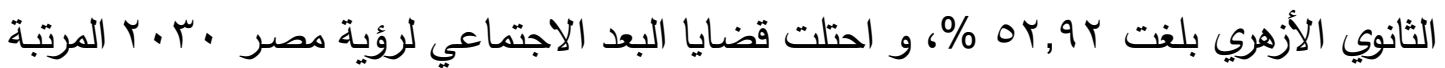

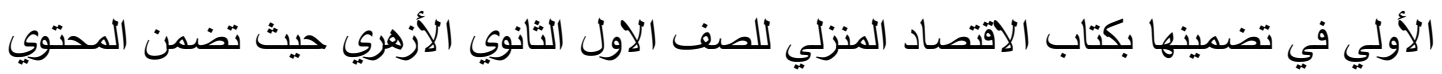

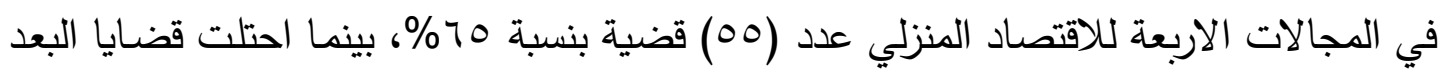

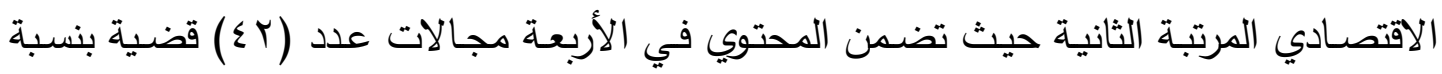

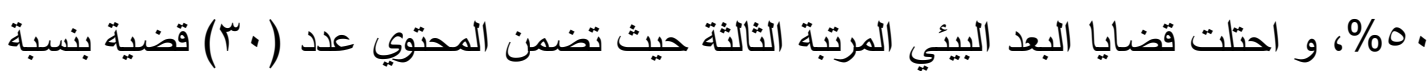

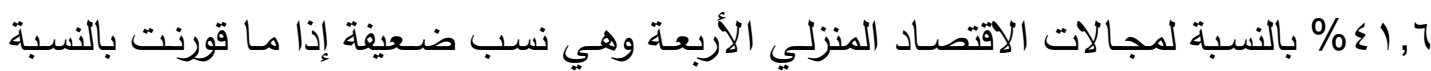

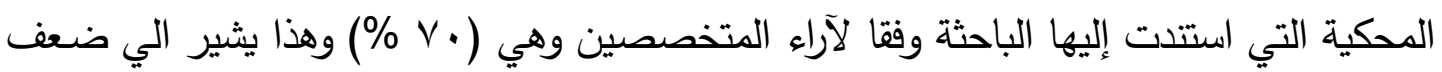

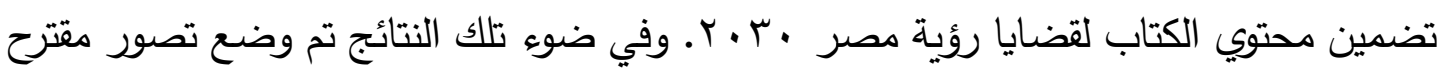

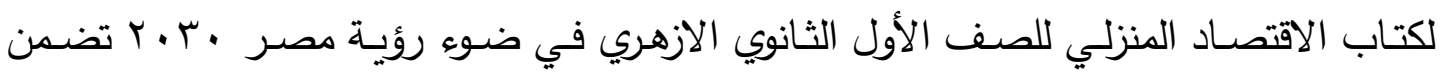

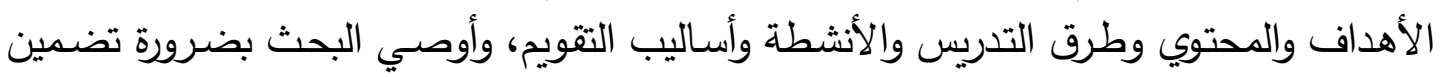

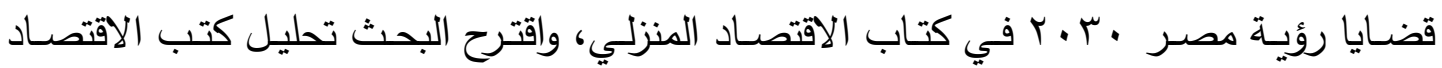

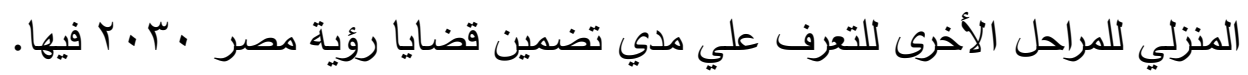




\title{
Evaluation of the home economics book for first-year students of Al-Azhar in the light of Egypt's 2030 vision and visualize a proposal according to its results
}

\begin{abstract}
The current research aims to evaluate the content of the home economics book for the first grade of Al-Azhar secondary school in the light of the dimensions of Egypt's 2030 economic, social and environmental vision. The research sample consisted of a book on home economics for the first grade of Al-Azhar secondary school in the Arab Republic of Egypt and used the descriptive analytical approach. The research tools was; a content analysis card to judge the level of the book content of home economics for the first grade of Al-Azhar high-school for the sub-issues identified in the list of subissues to the dimensions of Egypt's vision 2030 prepared by the current research, the idea was adopted as a unit for registration and the paragraph as a unit for analysis and repetition as a unit for the census, and the categories of analysis were represented in the sub-issues of the dimensions of Egypt's vision 2030 and a gradual scale of analysis was established in two levels. The results of the research concluded that the percentage of inclusion of the issues of dimensions of Egypt's vision 2030 as a whole in the home economy book for the first grade of Al-Azhar high-school reached 52.92\%, and the social dimension issues of Egypt's vision 2030 ranked first in including it in the book of home economics for the first grade of Al-Azhar secondary school, where the content in the four areas of home economics included (55) cases with a percentage of $65 \%$, while issues of the economic dimension ranked second where the content in the four areas included (42) cases, 50\%, and the environmental dimension issues were occupied At the third rank, the content included (30) cases with a percentage of $41.6 \%$ for the four domains of home economics, which are weak if compared to the spoken percentage that the researcher relied on according to the opinions of specialists, which is (70\%), and this indicates the book's lack of interest in Egypt's vision 2030 issues. In the light of those results, the research recommended that the issues of Egypt's vision 2030 should be included in the book on home economics, and a proposed concept was developed for the book of home economics for the first grade of Al-Azhar secondary school in the light of Egypt's vision 2030 that includes objectives, contents, teaching methods, activities and methods of evaluation, and the research suggested analyzing home economics books for the other stages to find out the extent to which Egypt's vision 2030 issues are included.
\end{abstract}




\section{مق بدمه}

إذا كان للتربية أدواتها لإحداث تغيرات جذرية في المجتمعات وصولا لأفضل المخرجات

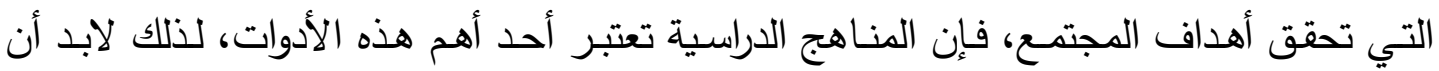

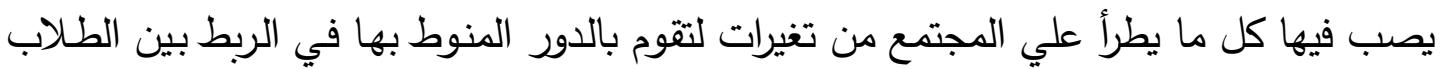

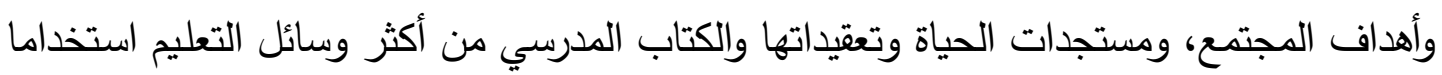

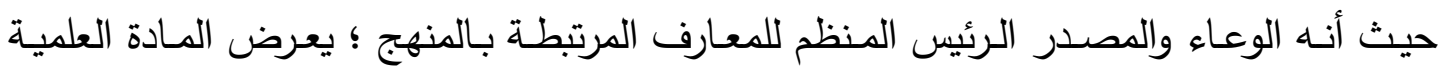

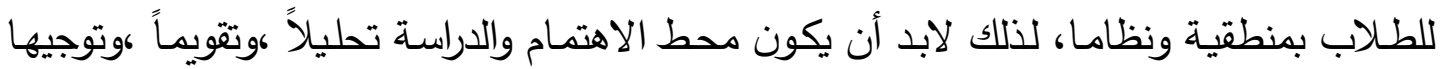

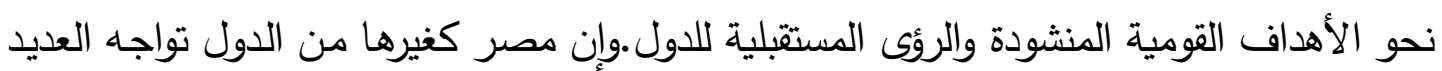

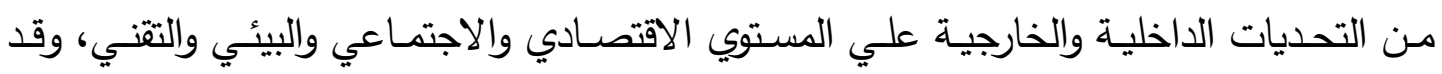
حرصت علي وضع استراتيجية لمواجهة تلك التحديات والتعامل معها بمهارة ومرونه.

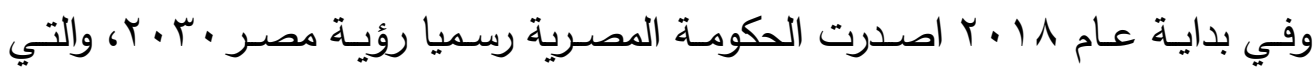
تهدف إلى رفع الروح الوطنية المصرية، وتجمع بين ادارات التتمية الوطنية لتجني توافق الآراء

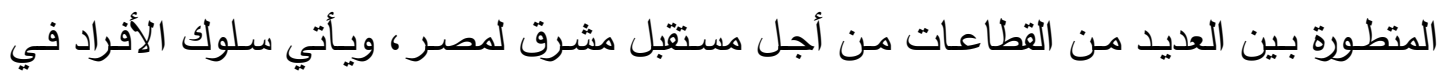

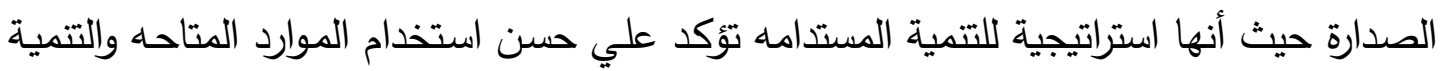

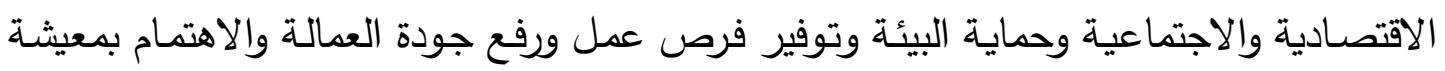

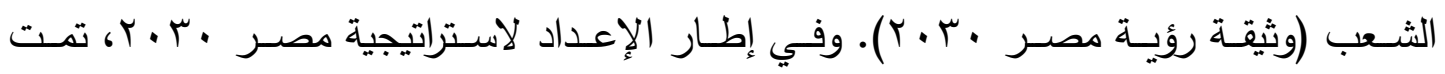

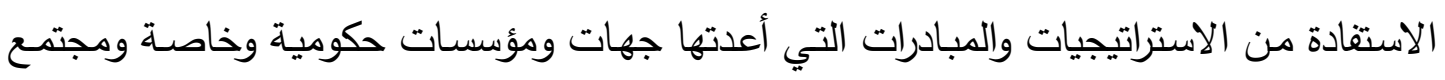

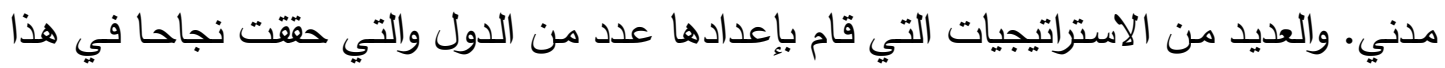

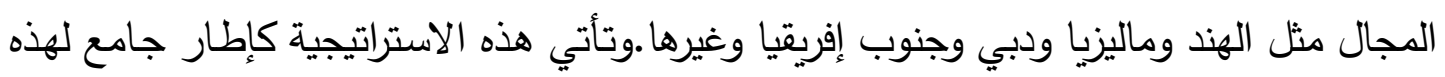

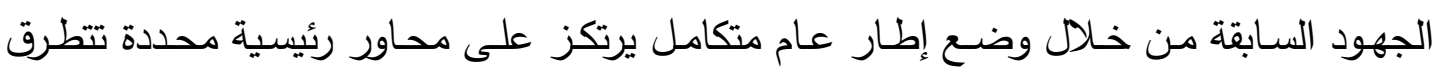

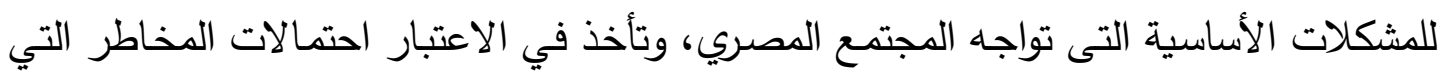

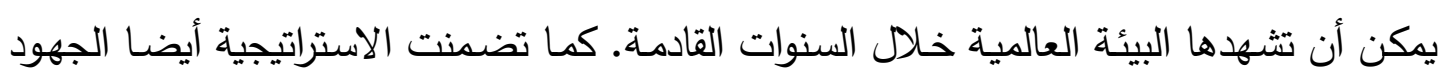

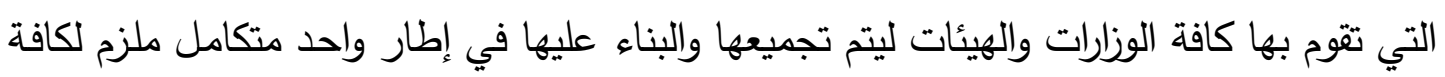

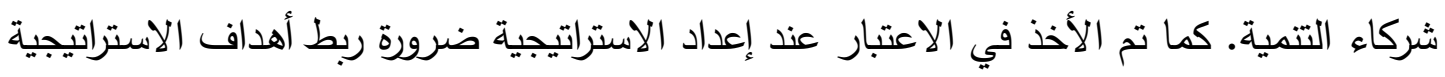
بمؤشرات أداء محددة وقابلة للقياس يتحمل مسئولية تتفيذها جهات محددة، وواقعية ومرتبطة بمدى الإن زمني محدد وتتاسب وترتبط بدرجة كبيرة بأهداف التتمية المستدامة لما بعد 10 ـ ب التي أطلقتها 


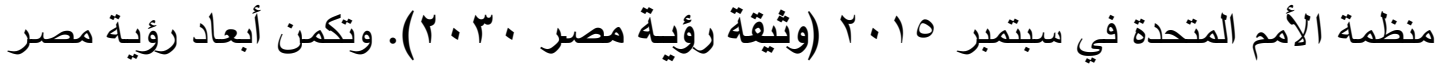

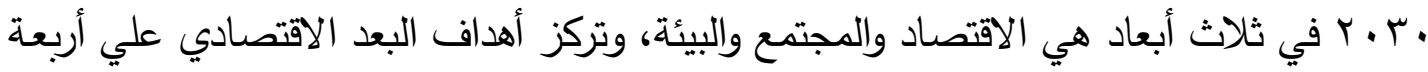

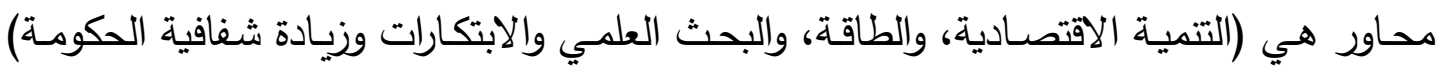

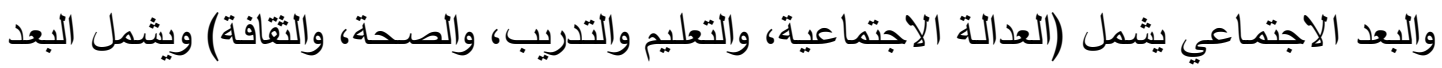
البيئي (حماية البيئة والتتمية الحضرية المستدامة).

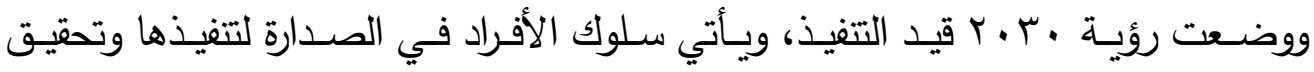

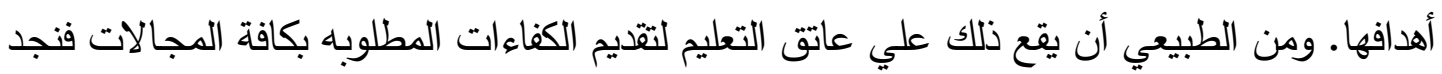

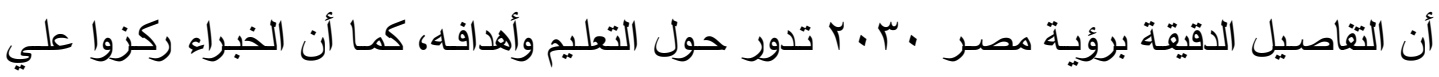

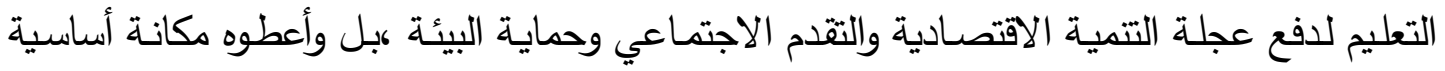

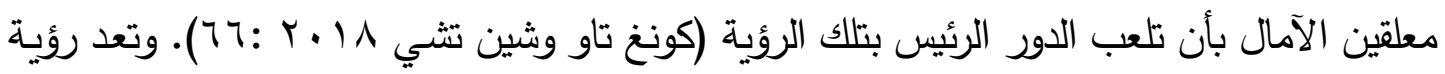

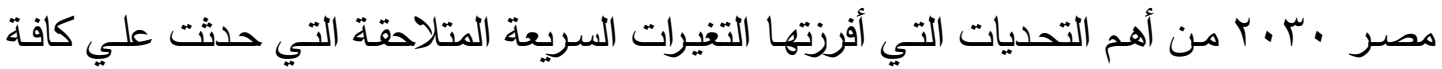

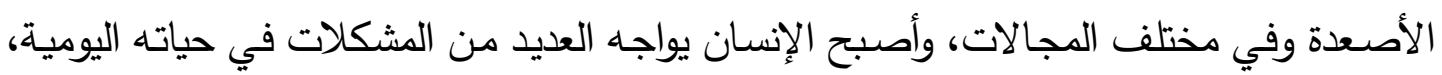
لذلك كان لزاما علي الدولة أن تواجه هذا التحدي من خلا كل كافة مؤسساتها الاجتماعية.

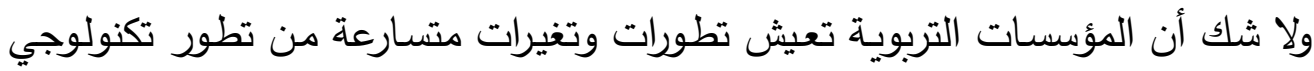

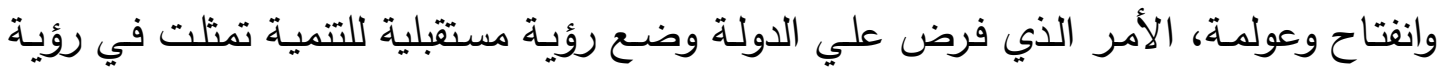

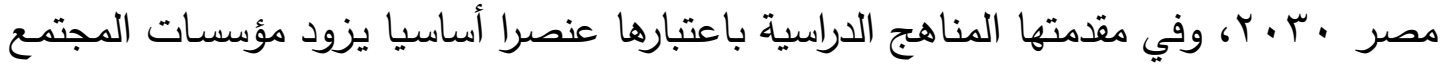

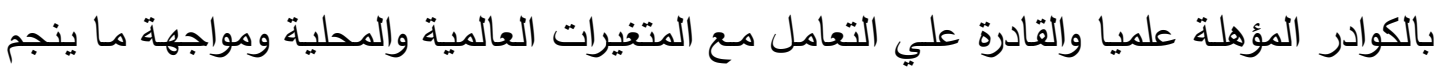

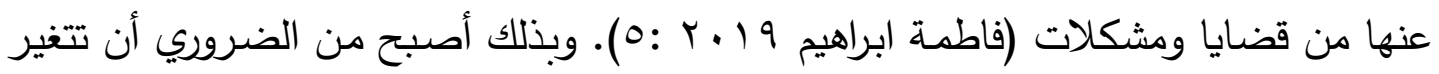

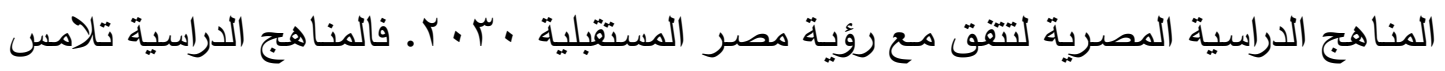

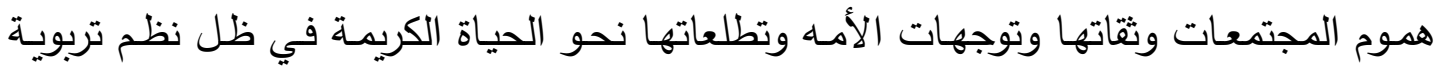

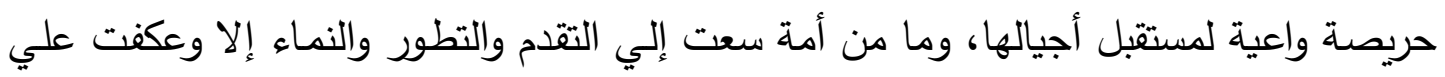

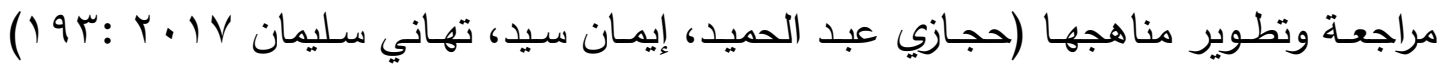

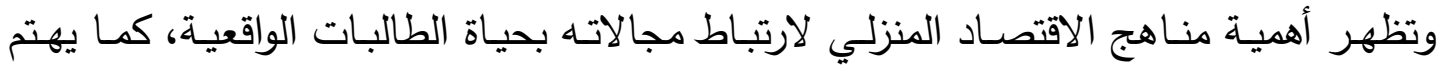

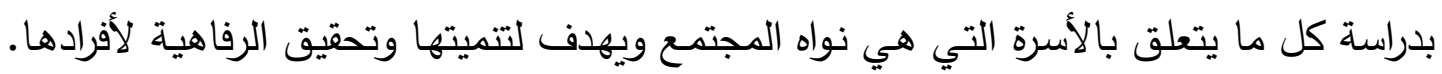

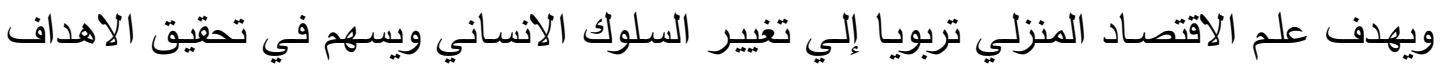

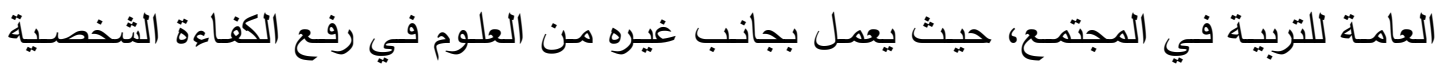

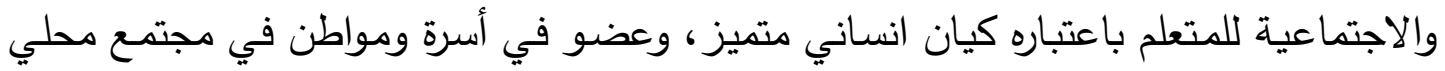

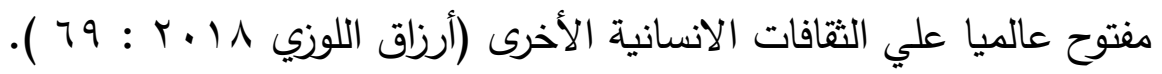


وممـا لاشكك فيـه أهميـة تقويم الكتاب المدرسي بهدف تطـويره ليكون أداه فاعلـة في عمليتي التعليم والتعلم، لأن تقويم الكتاب المدرسي وسيلة من الوسائل المهمة في معرفة مدي صلاحيته وجودته ومناسبته لحاجات الطلاب وأهداف المجتمع. وبتحليـل الوضـع الـراهن لواقع مقررات الاقتصـاد المنزلـي بالمراحل التعليميـة المختلفـة يكثف عن قصورفي عمليات ربط محتوي المقررات والتدريس بالاحتياجـات التعليمية الفعلية للطالبات؛ فلا اهتمام بنوعية الاحتياجات التعليمية التي تختلف باختلاف بيئة التعلم، ولا بشدة الاحتياجات وأولوياتها بالنسبة لكل بيئة منها، وهو الأمر الذي يمكن أن يحدث طفرة في أساليب تصـميم المقـررات الدراسـية ونظم تدربسها ويحسن مـن ممارسـات الطـلاب المرتبطـة بالتنميـة المستدامة واتجاهاتهم نحو الحياة ومستقبل الأجيال القادمة إذا تم وضعهد في الاعتبار (تغريد

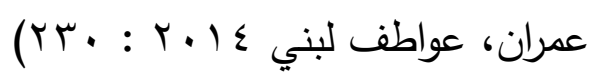
وعلـي الـرغم مـن تطـوير كتـب الاقتصـاد المنزلـي للمرحلـة الثانويــة العامــة عـام

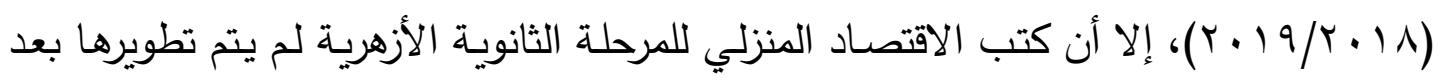

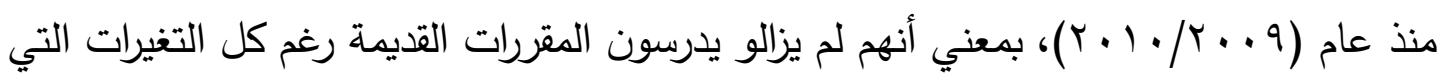
تعرض لها المجتمع المصري سواء اقتصاديا أو اجتماعيا أو بيئيا أو تكنولوجيا في ظل الثورة العلمية والتكنولوجية المتسارعة وما ينجم عنها من تغيرات في شتي نواحي الحياة، وبالتالي لم تتطرق تلك الكتب للأهداف العامه المستحدثة للمجتمع في الوقت الحالي. كما أنه في حدود علم الباحثة لم تخضع كتب الاقتصـاد المنزلي في مصر للتقويم في

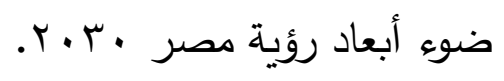

علي الرغم من تكرار الدعوات التي انطلقت وفقا لنتائج الأبحاث لتضمين أبعاد رؤيسة مصر

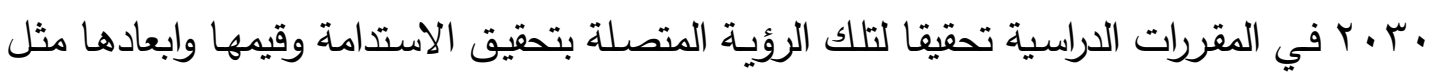

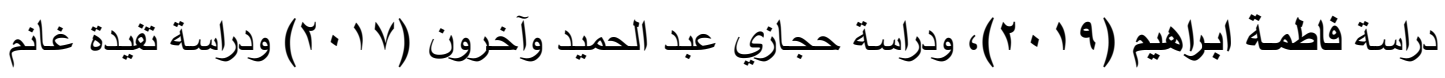

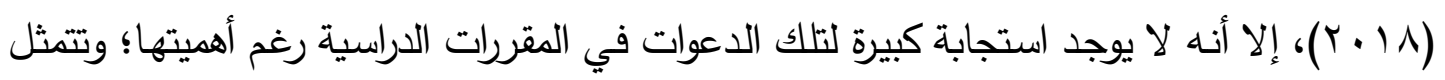
مشكلة البحث الحالي في وجود ضعف في معالجة مقرر الاقتصاد المنزلي للصف الأول الثانوي

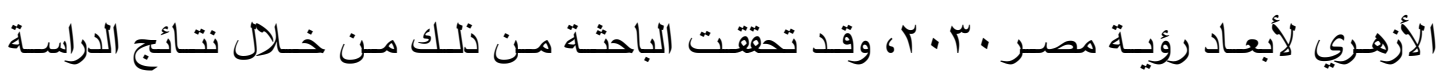


الاستطلاعية التي قامت بها عن طريق تحليل محتوي عينة اسنطلاعية من كتاب الاقتصاد المنزلي للصف (الأول الثانوي الأزهري) وقد اتضح من نتائج التحليل ضعف توظيف مفردات المحتوي لها

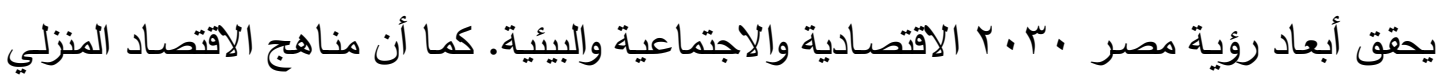

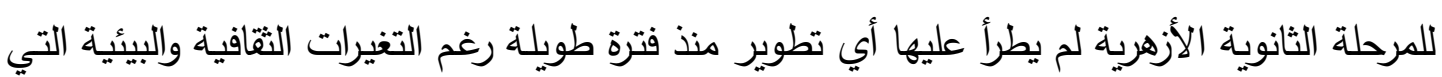
طرأت علي المجتمع كالثورة المعرفية والتكنولوجية والتتمية المستدامة والتغيرات الاجتماعية والثقافية. ويسعي البحث الحالي لدراسة واقع كتاب الاقتصاد المنزلي للصف الأول الثانوي الأزهري من حيث الهيك

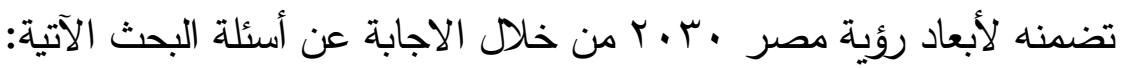

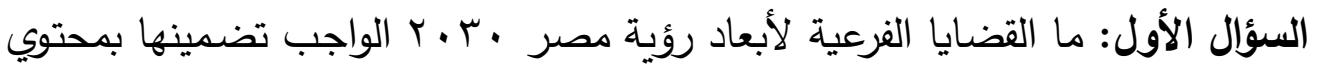

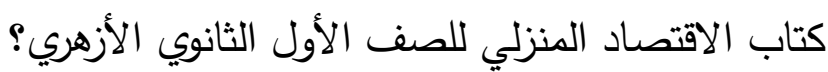

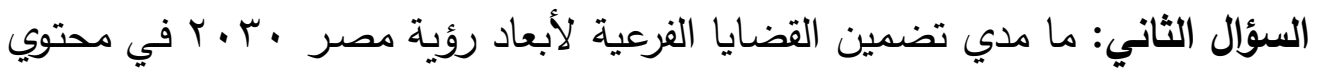
كتاب الاقتصاد المنزلي للصف الأول الثانوي الأزهري؟

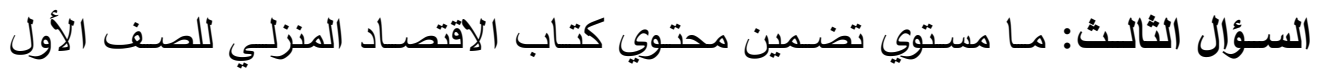
الثانوي الأزهري لقضايا الابعاد الاقتصادية والاجتماعية والبيئية لرؤية مصر • ب. ب في مجال (ادارة مؤسسات الأسرة والطفولة)؟ هالسؤال الرابع: ما مستوي تضمين محتوي كتاب الاقتصاد المنزلي للصف الأول الثانوي

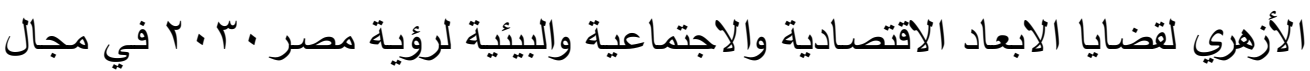

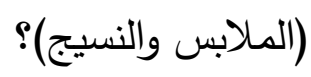
السؤال الخـامس: مـا مستوي تضمين محتوي كتاب الاقتصـاد المنزلي للصف الأول

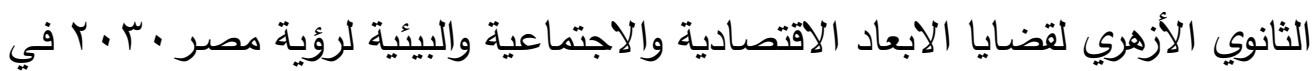

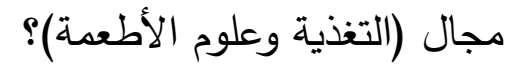
هالسؤال السـادس: مـا مستوي تضمين محتوي كتاب الاقتصساد المنزلي للصف الأول

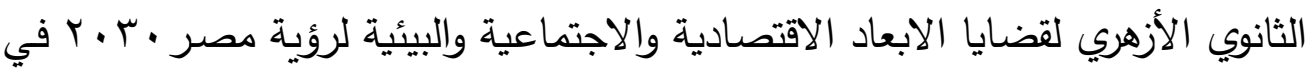

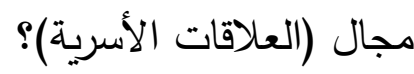
السؤال السابع: ما التصور المقترح لمقرر الاقتصاد المنزلي للصف الأول الثانوي في

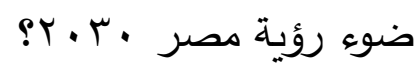




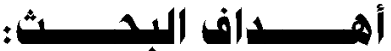

سعي البحث الحالي إلي تحقيق الأهداف الأتية : بناء قائمة بقضايا الأبعاد (الاقتصادية، والاجتماعية، والبيئية) عند اختيار وتتظيم محتوي الاهدي الاتية

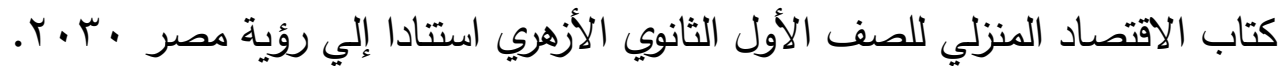

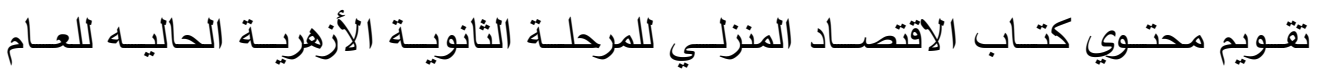

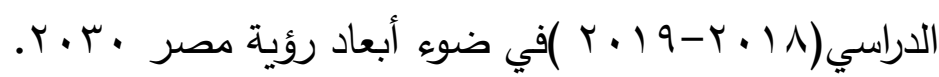

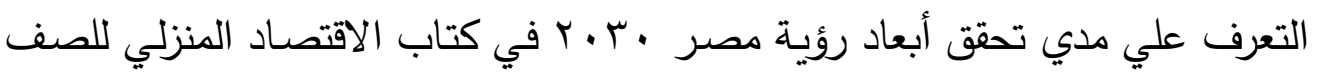

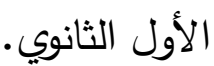
تقـديم تصــور مقتـرح لمقـرر الاقتصـاد المنزلـي للصـف الأول الثـانوي فـي ضــوء

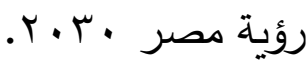

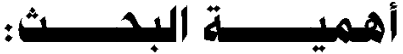

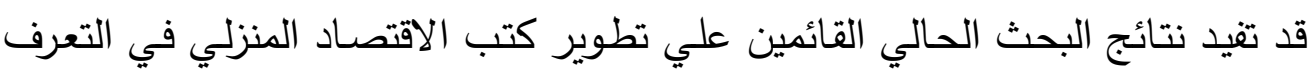
علي أوجها القوة والضـف في كتاب الاقتصـاد المنزلي للصف الأول الثانوي الأزهري لتطويرها في ضوء الاهداف الاستراتيجية القومية. قد يكون البحث الحالي نقطة انطلاق لابحاث أخري حيث تناول موضوع الانتية تحليل محتوي

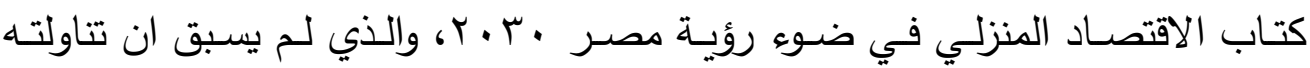
ابحاث أخري في المجال (في حدود علم الباحثة). قد يقدم البحث الحالي تصورا مقترحا لدقرر الاقتصاد المنزلي للصف الأول الثباد الثانوي في

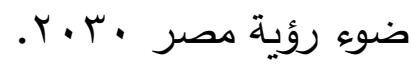

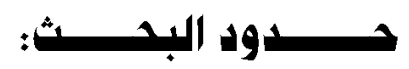

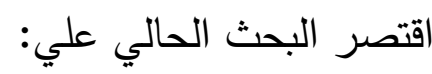

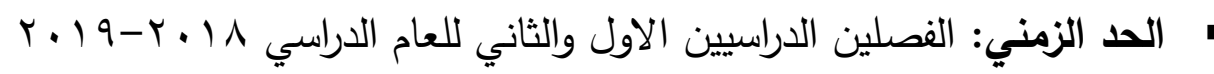

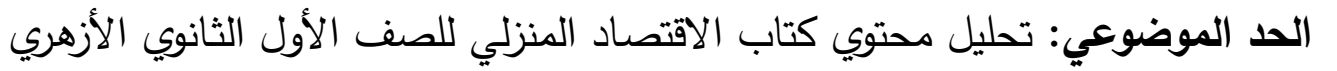

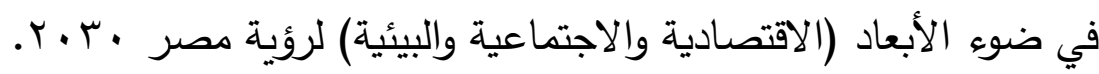

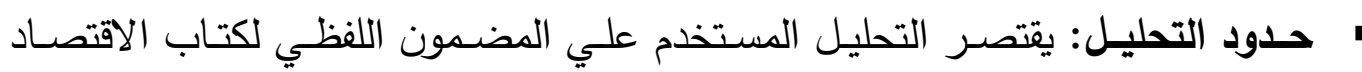

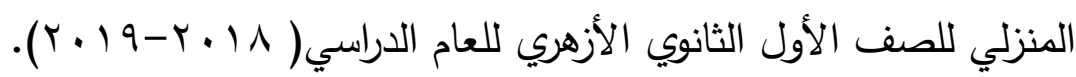




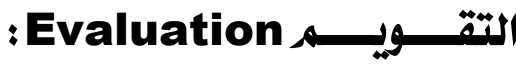

هي عملية تقرير قيمة الثئ أو كميته وهدفه الحكم الموضوعي علي العمل المقوم صلاحا وفسادا، نجاحا وفثـلا بتحليل المعلومات المتيسرة عنه وتنسيرها في ضوه العوامل والظروف التي من شأنها أن تؤثر علي العمل بقصد تحسين وتطوير هذا العمل (حسن شحاته وزينب النجار

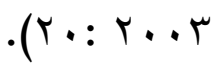

ويعرف في البحث الحالي بأنـه عملية تقرير قيمة كتاب الاقتصاد المنزلي في ضوء أبعاد

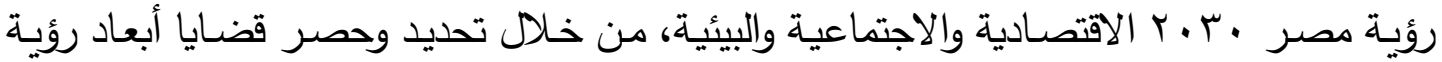

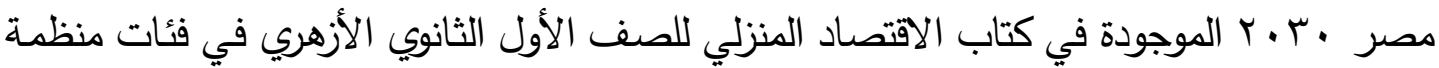
وموضوعية باستخدام بطاقة تحليل المحتوي.

\section{الكتـاب المسلدرسي Textbook}

يعرف في البحث الحالي بأنه مؤلف تعليمي يحتوي المادة التعليمية المقررة علي طالبات

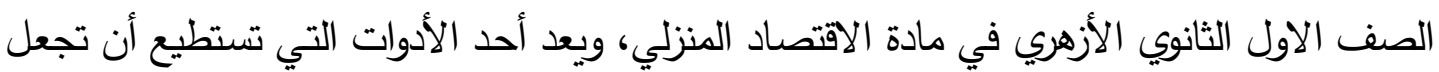
الطالبات قادرات علي بلوغ أهداف المنهج المحدة سلفا.

\section{رؤيسـة مصسر •Egypt Vision r.r.}

هي مبادرة أطلقتها الحكومة الدصرية في 1 ـ ـ بلبدء خطة استراتيجية للتنمية الثاملة في

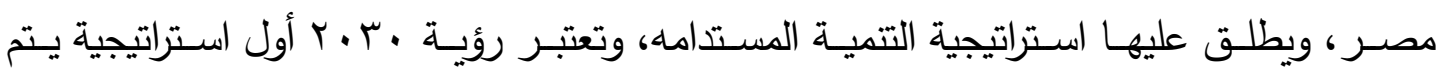
صياغتها وفقاً لمنهجية التخطيط الاسراتيجي بعيد المدى والتخطيط بالمشاركة، لوضع هدفاً أساسياً

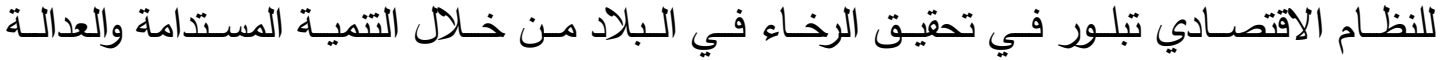
الاجتماعية، وتؤكد على ضرورة التزام النظام الاقتصادي المصري بالنمو المتوازن جغرافياً وقطاعياً

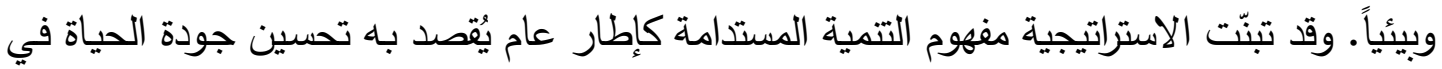

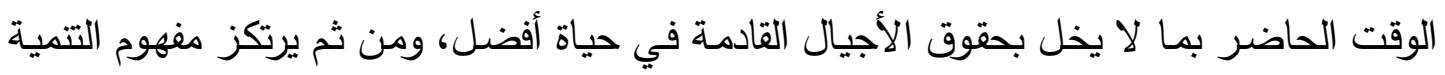

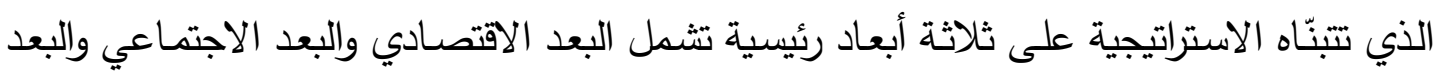

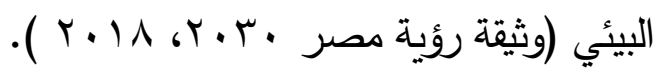




\section{أولاً : رؤية مصر•r.r (استراتيجية التنمية المستلامه ) :}

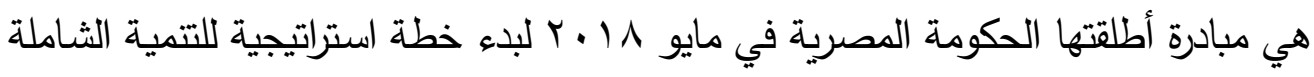

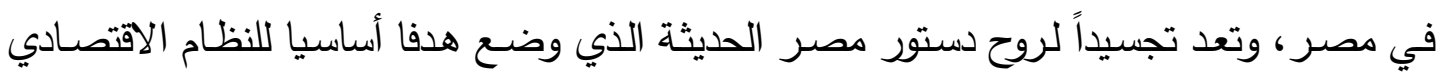

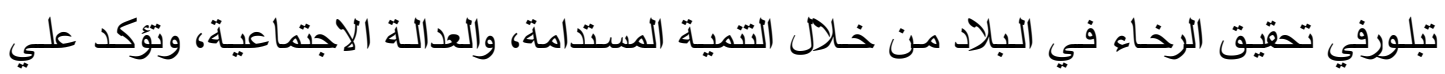

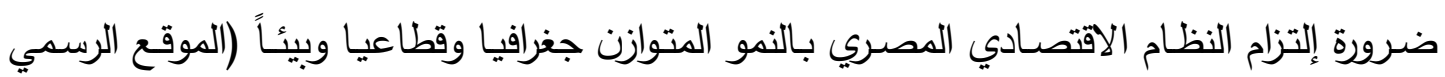

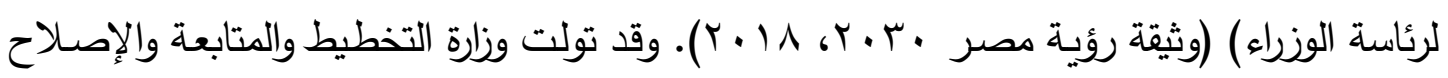

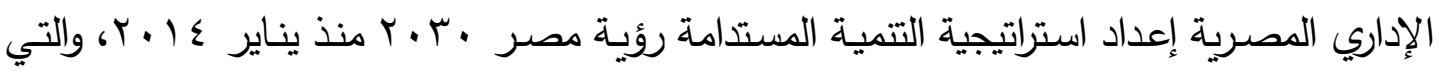

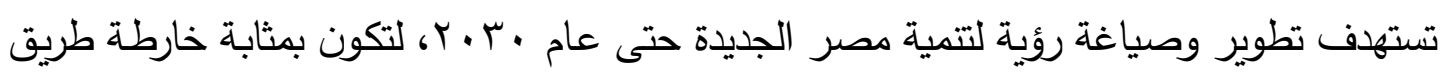

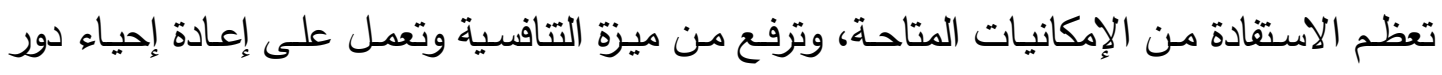

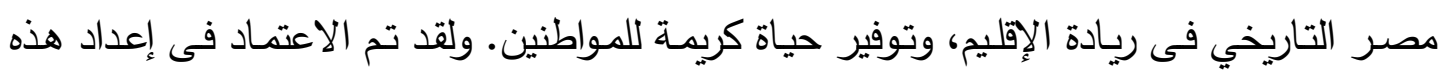

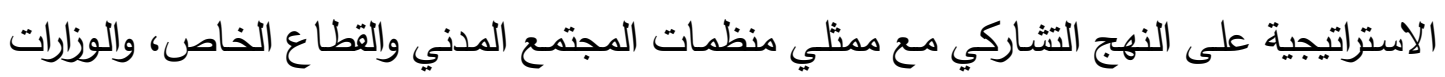
والخبراء والأكاديميين. كذلك تم عقد العديد من ورش العمل مع: مالوكالات الدولية من بينها منظمة العمل الدولية. • • • صندوق الأمم المتحدة للأنشطة السكانية. • هيئة الأمم المتحدة للمرأة. • الوكالة الأمريكية للتمية الدولية، والبنك الدولي.

وتأتي هذه الاستراتيجية كإطار جامع لجهود المؤسسات المختلفة بمصر من بن خلال

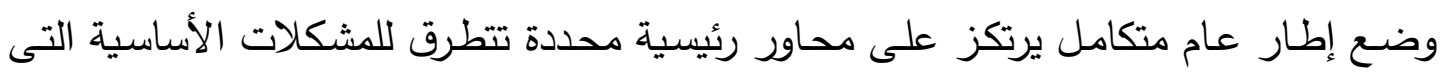
تواجه المجتمع المصري؛ وتأخذ في الاعتبار احتمالات المخاطر التي يمكن أن تشهدها البيئة

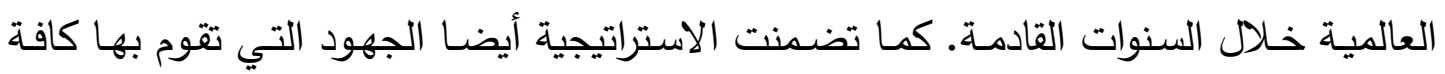

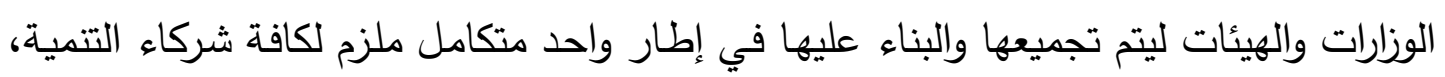
كما تم الأخذ في الاعتبار عند إعداد الاستراتيجية ضرورة ربط أهداف الاستراتيجية بمؤشرات

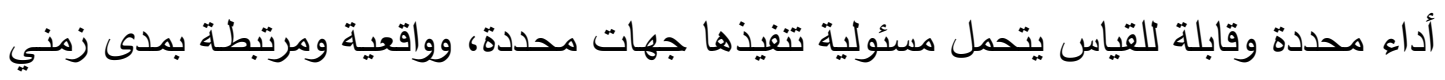

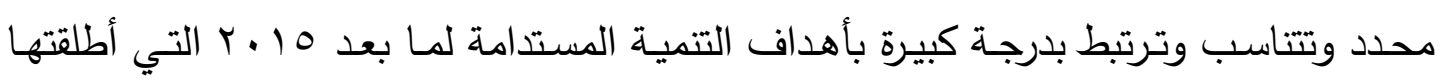

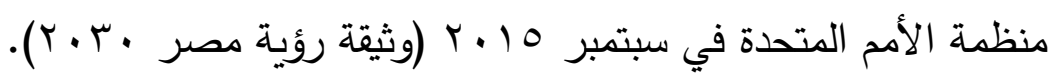




\section{أهمية وأهداف استراتيجية التنمية المستدامة "رؤية مصر •"م ·"}

تأتي أهمية هذه الاستراتيجية خاصة في ظل الظروف الراهنة التي تعيشها مصر بأبعادها المحلية والاقليمية والعالمية، والتي تتطلب اعادة النظر في الرؤية التتموية لمواكبة هذه التطورات

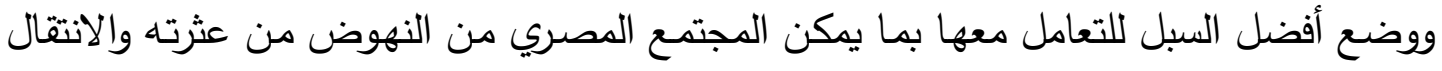
الي مصاف الدول المتقدمة، وتحقيق الغايات التتمويـة المنشودة للبلاد. وقد تبنت الاستراتيجية مفهوم التتمية المستدامة كإطار عام يقصد به تحسين جودة الحياة في الوقت الحاضر بما لا يخل

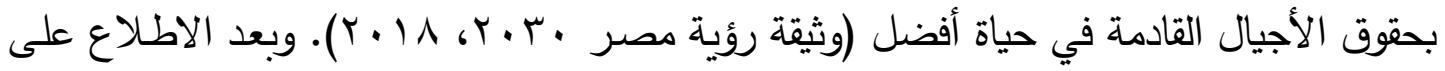

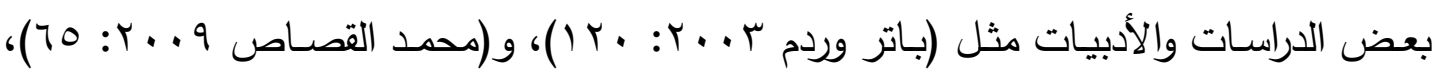

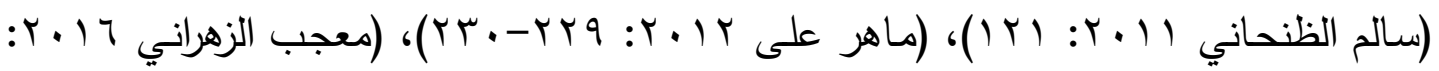
•) يمكن تلخيص بعض أهداف التتمية المستدامة كما يلي: (ملي:

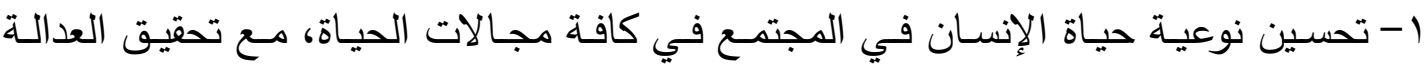

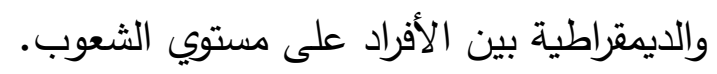

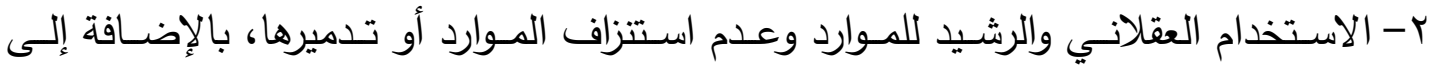
استغلالها وتوظيفها بشكل عقلاني، والعمل على تطوير العلاقة بين الإنسان والبيئة لتصبح علاقة تكامل وتوازن وانسجام. r- إعـادة توجيه التكنولوجيا الحديثة لتحقيق أهداف المجتمع: وذلك من خـلاد تثقيف الناس بأهمية التقنيات المختلفة في المجال التمويله ع- تعزيـز إمكانيـة الحاضـر والتنكيـر في المستقبل ومصـير الأجيـال القادمـة، وذلكك لتلبيـة الحاجات الإنسانية، لأن التنمية المستدامة في جوهرها عملية تغيير ؛ يكون فيها استغلال

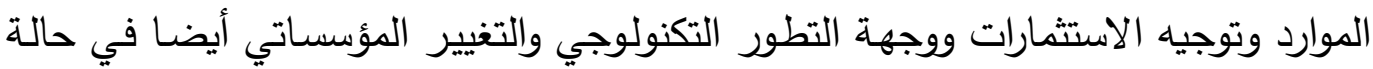
انسجام وتوافق، كما أن عامل "الوقت والمستقبل" هما أهم ما يميز التتمية المستدامة.

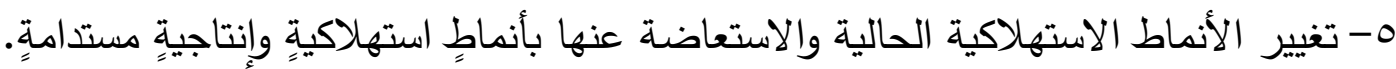

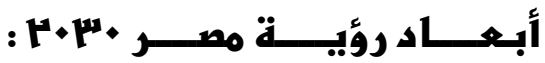

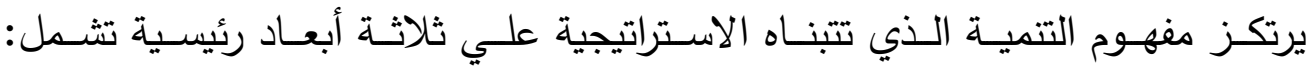

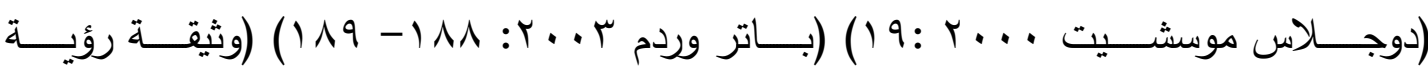
مصر •r. .r، 1) (Y). 


\section{البعد الاقتصادي ويشمل: - ال}

يستند البعد الاقتصـادي لمبدأ الذي يقضـي بزيـادة رفاهيـة المجتـع إلى أقصـي حد،

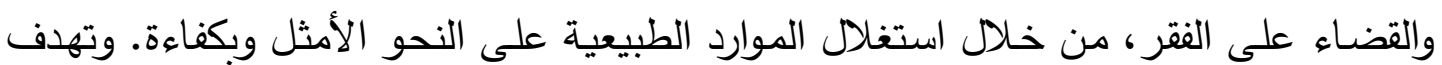

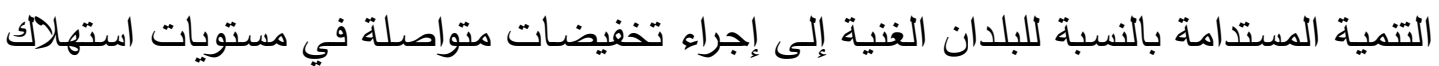
الطاقة والموارد الطبيعية التي تصل إلى أضعاف أضعافها في الدول الغنية مقارنة بالدول الفقيرة

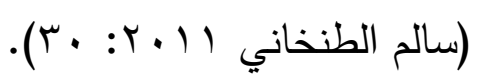

محسور التنميـة الاقتصـادية: ويشمل استقرار اوضـاع الاقتصـاد الكلي، تحقيق نـو احتوائي مستدام، زيادة التتافسية والتتوع، مساهمة الخدمات في الناتج المحلي الاجمالي.

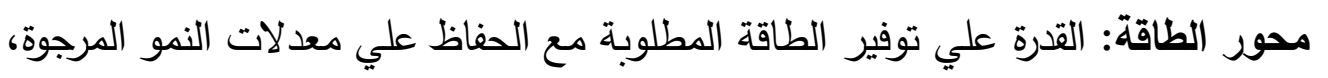

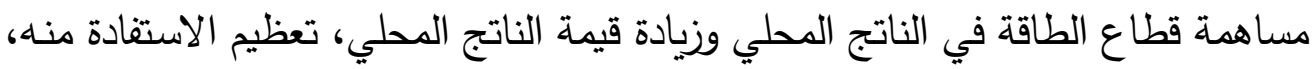
تعزيز الادارة الرشيدة، خفض الملوثات، الحد من الاثر البيئى للانبعاثات.

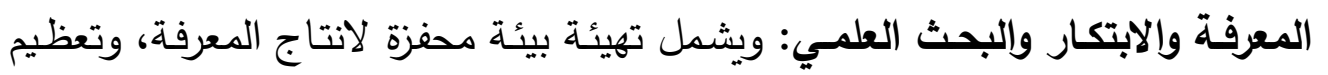
الانتاج المعرفي ،تطوير نظام متكامل للابتكار ،زيادة الترابط بين الابتكار والاحتياجات وتطوير التعليم والبحث العلمي الثفافية وكفاءة المؤسسـات الاجتماعيـة (وثيقة رؤيـة

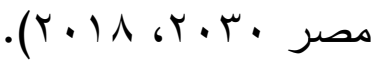

$$
\begin{aligned}
& \text { البعـــــ الاجتمـــــاعــــي: }
\end{aligned}
$$

ويهدف لأن يكون هنالك جهاز اداري كفه: من خـلال بنـاء مجتمـع عادل متكاتف

يتميز بالمساواة في الحقوق والفرص وباعلي درجة من الاندماج المجتمعي من خلال:

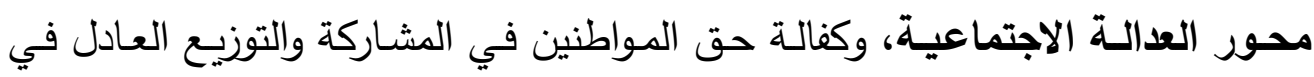
ضوء معايير الكفاءة والانجاز ، مساندة شرائح المجتمع المهمشة.

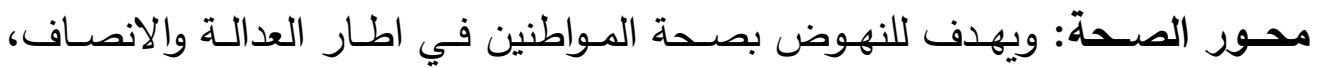
الاهتهـام بكل مـا يـؤثر في الصـحة، وتحفيز نمط الحيـاة الصـحية، تحقيق التغطيـة

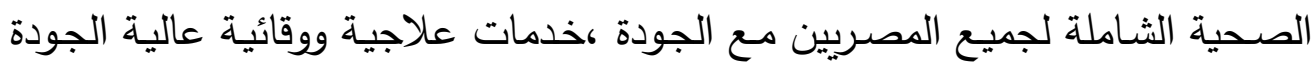
ومتاحة للجميع، حوكمة قطاع الصحة. " محور التعليم والتـدريب: اتاحة التعليم بجودة عالية للجميع دون التييز وفي إطار مؤسسي وكفه وعادل ومستدام ومرن، وأن يكون مرتكز علي المتعلم المتدرب القادر 
علي التفكير والتمكن فنيا وتكنولوجيا، وأن يساهم في بناء الثخصية المتكاملة واطلاق

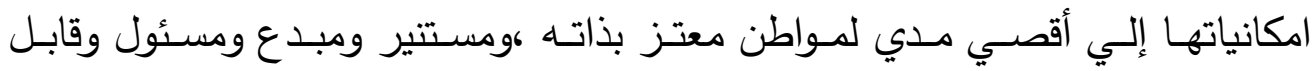

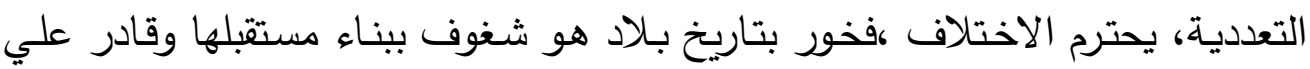

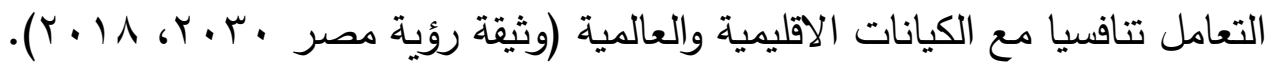

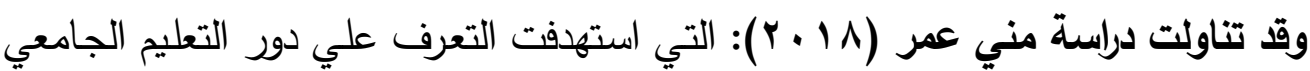

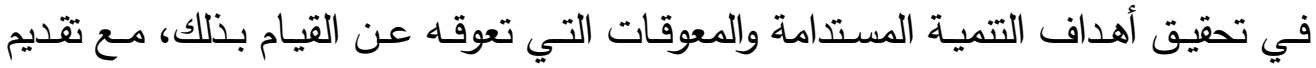

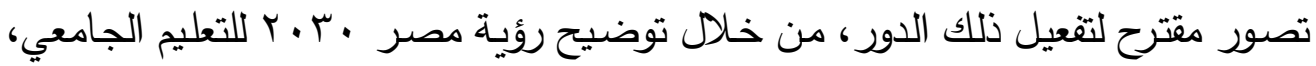

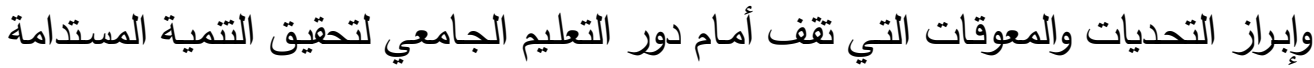

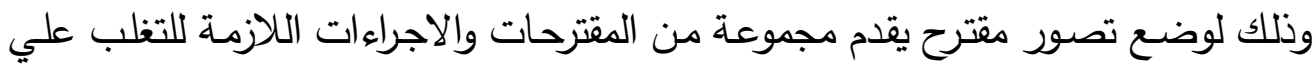

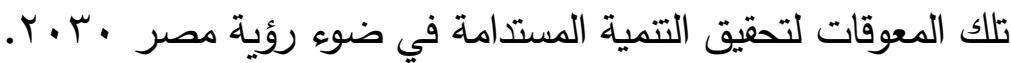

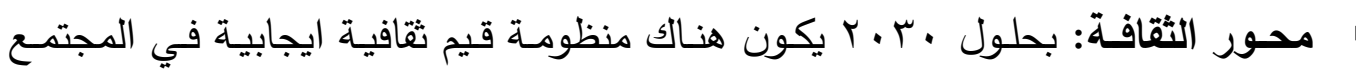

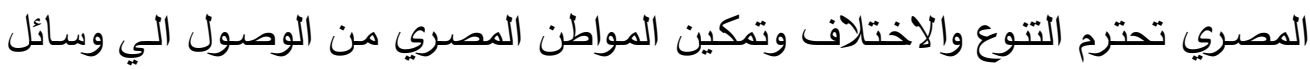

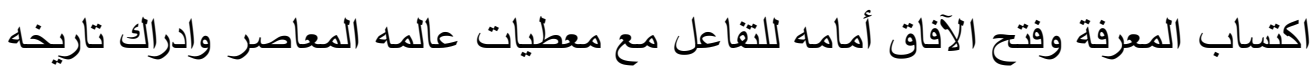

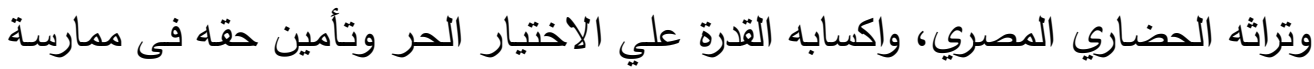

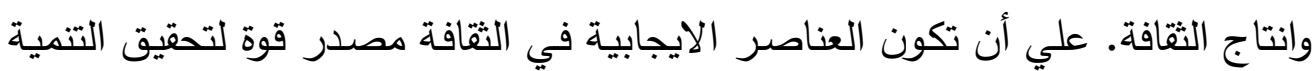
وقيمة مضافة للاقتصاد القومي وأساسا لقوة مصر الناعمة اقليميا وعالميا (وثيقة رؤية

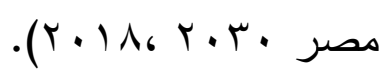

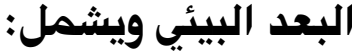

يعمل البعد البيئي على حمايـة النظم البيئية وسـلامتها، وحسن التعامل مـع المـوارد الطبيعية وتوظيفها لصالح الإنسان دون إحداث الخلل في مكونات البيئة كالأرض والماء والهواء لما لهم من أهمية في الحفاظ على ديمومة الحياة البشرية والحيوانية ووضع تشريعات لحماية

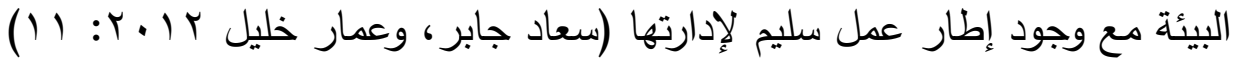

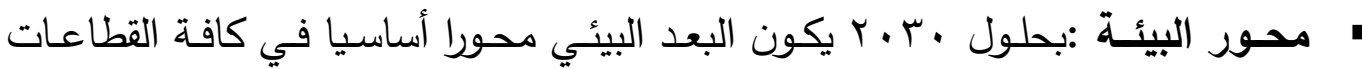

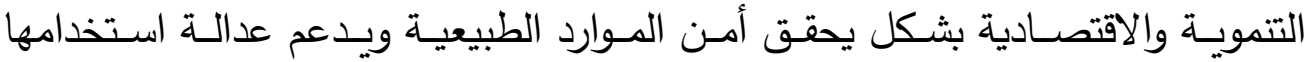
والاستغلال الأمثل لها والاستثمار فيها، بما يضمن حقوق الأجيال القادمة فيها ،ويعمل

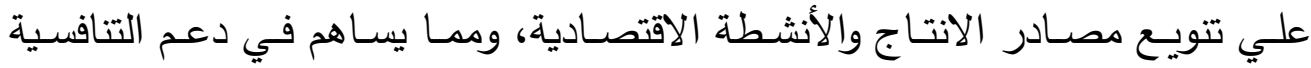


وتوفير فرص عمل جديدة والقضاء علي الفقر ، ويحقق عدالة اجتماعية مـع توفير بيئة

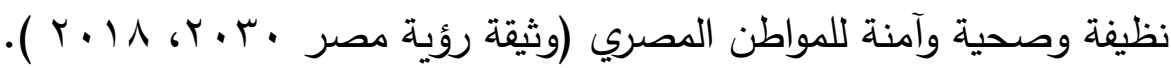

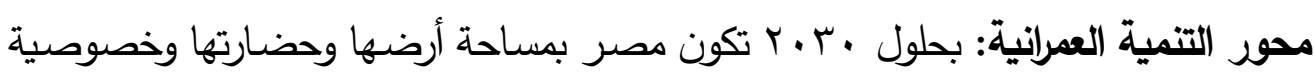
موقعها قادرة علي استيعاب سكانها ومواردها في ظل ادارة تتمية مكانية أكثر اتزانا وتلبىى

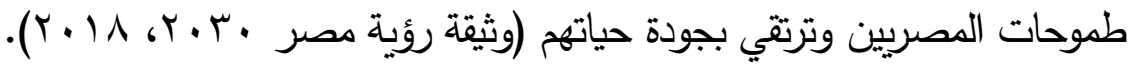

وقد تتاولت بعض الدراسـات السـابقة رؤيسة مصر بالتحليل للكثف عن بعض الجوانب

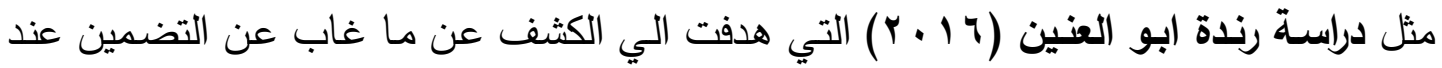
التخطيط والتطبيق لاستراتيجية • ب • للتتمية المستدامة مسن خـلال خمسـة مباحث هي ماهيـة

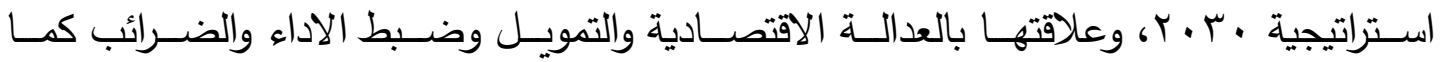
استعرضت أهمية الديموقراطية ودورها واهمية استغلال طاقات الشعب المصري ورغبته في الابداع واستغلال ثروات مصـر الطبيعيـة، وقد أظهرت الدراسـة عـن بعض الجوانب التي غابـت عـن

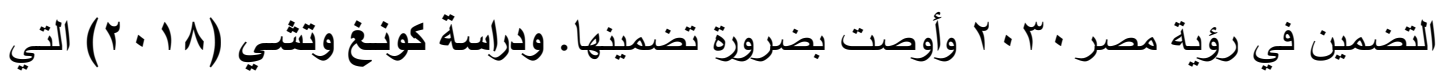
هدفت الي تحليل استراتيجية تطوير التعليم في مصر رؤيسة .ب • rبهدف دفع التعاون التعليمي والتبادل الثقافي وتطور وازدهـار العلاقات بين أقدم حضـارتين الصـين ومصـر واتبعت الدراسـة المنهج الوصفي التحليلي حيث قامت بوصف الوضع الحالي للتعليم الأساسي في مصر منذ عام

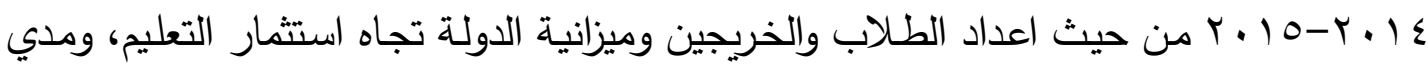

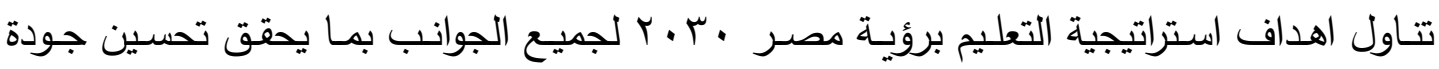
التعليم بالمقاييس الدولية، واستعرضت الدراسة مؤشرات رفع جودة التعليم بمراحلة وبما فيه التعليم

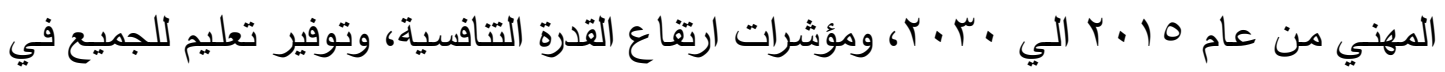

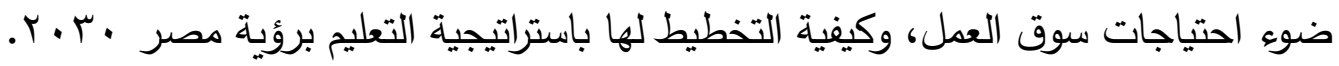
ومن الملاحظ ندرة الدراسات السابقة التي تتاولت رؤيسة مصر • ب • ب بالدراسـة والتفنيد للتعرف علي جوانب القوة والضـف فيها وتقديم توصـيات واقتراحسات تتــاول كل محور من محاورها، وقد يكون سبب ذلك حداثتها علي المجتمع، أو ما يشوب التتمية المستدامة بشكل عام

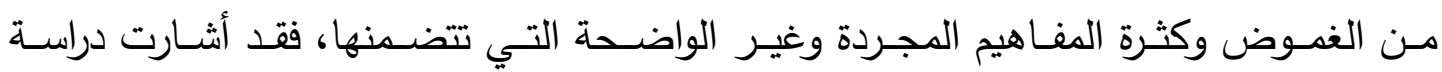
(Borg etal., 2017) أظهرت أن التخصص يجعل كل فريق ينتقد مفهوم التتمية المستدامة في احد ابعاده. 


\section{الاقتصاد المنزالي ورؤية مصر •"م+H :}

يعد مقرر الاقتصـاد المنزلي من المقررات الهامة والمؤثرة، فعلم الاقتصـاد المنزلي هو علم يرتبط بالانسان واحتياجاته وميوله واتجاهاته وتطوره منذ اللحظة الأولي من ولادته إلي نهايـة عمره ومـا يحدث خـلال هذه الفترة لمقابلـة احتياجاته، فهو علم تطبيقي يهتم بدراسـة

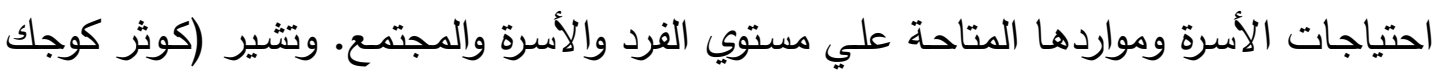

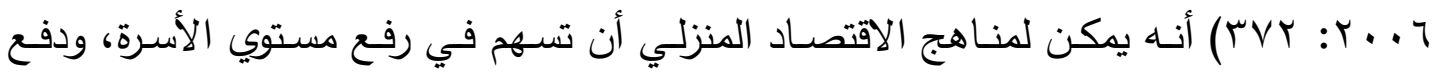

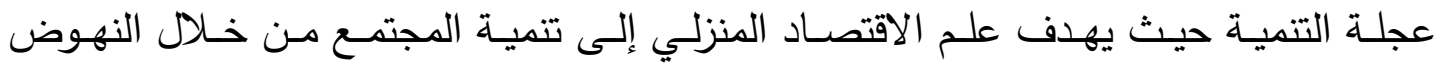

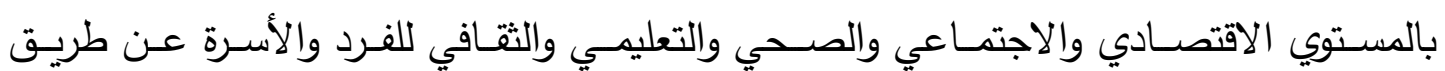
الاستخدام الأمثل للطاقات البشرية.

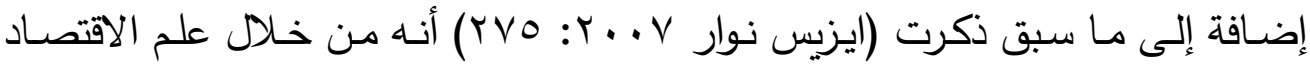
المنزلي يتعلم الفرد كيفية إدارة الموارد الأسرية البشرية وغير البشرية، واستخدامها بأعلى كفاءة

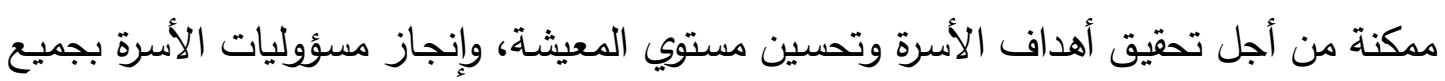
أنواعها الاقتصادية والاجتماعية والبيئية والنفسية، والجسمية، وتعد كل هذه الأمور من الأهداف الرئيسة لتحقيق متطلبات التتمية المستدامة. وإذا كان للاقتصاد المنزلي دورٌ هام في بناء الإنسان

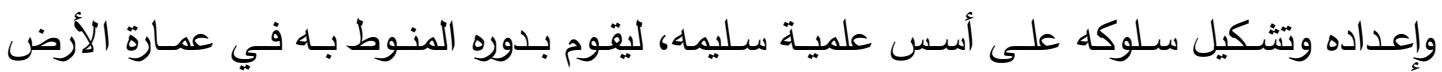
والاستخلاف فيها، فإن معلدة الاقتصساد المنزلى لها دورٌ كبيرٌ في تتمية وعي الطالبات وبالتالي

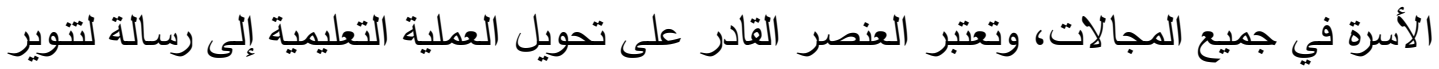

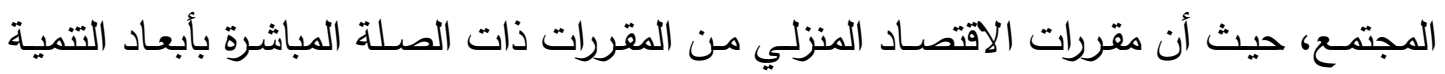

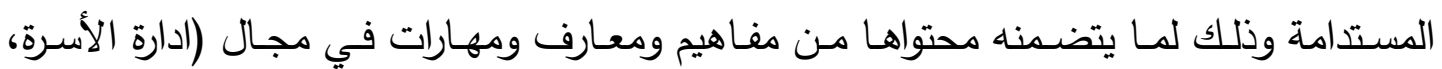
والغذاء والتغذية، والمسكن والملبس، والعلاقات الأسرية والطفولة والأمومة) وما تسعي الي تحقيقة

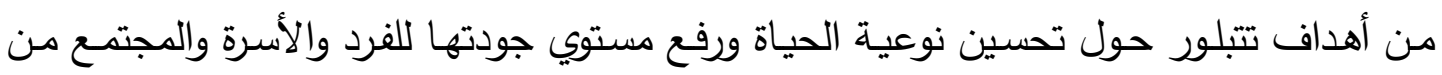

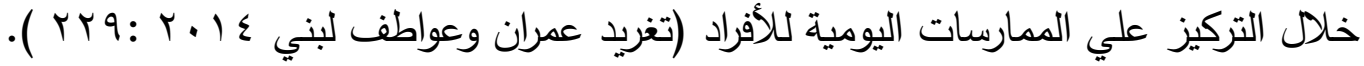
وعلي ذلك فإن تضمين محتوي مقررات الاقتصـاد المنزلي لأبعاد التتميـة المستدامة

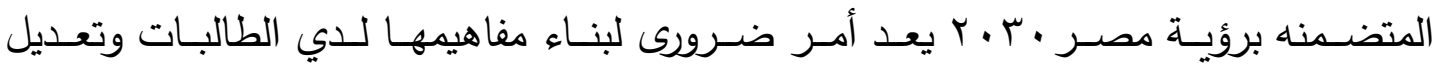
ممارساتهن الخاطئة نحو موارد البيئة، والتوعية بالمخاطر الناجمة عن سوء استخدام تلك الموارد علي الجيل الحالي والاجيال القادمة، وتكوين اتجاهات إيجابية نحوها. وقد هدف البحث الحالي

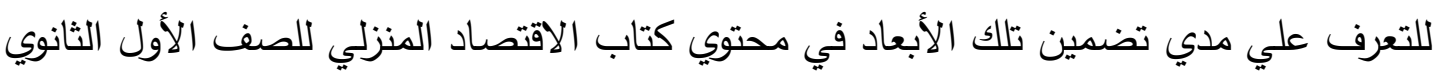


الأزهري للوقوف علي الواقـع الفعلي، فالكتـاب المدرسي هو المصدر الرئيس لتعلم الطـلاب ويشمل المحتوي المعرفي اي المعرفة المنظمة. وترجع أهمية الكتاب المدرسي إلي أنه المرجع العلمي الأول للمعلم والمتعلم كما يسهم في نقل ثقافة المجتمع إلي المتعلمين ويضـع إطاراً عاماً

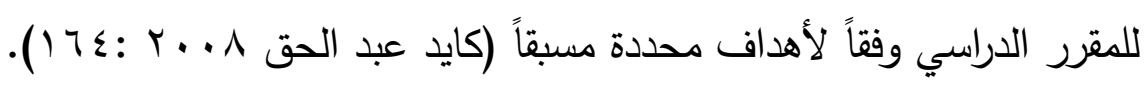
وقد تناولت بعض الدراسـات السـابقة تحليل بعض المقررات والكتب الاراسية للتعرف علي مدي تضمين رؤية مصر · ب • r أو أبعاد التتمية المستدامة من حيث مدي توافر مضامينها ومفاهيمها ومتطلبات تحقيقها في المقررات الدراسية المختلفة مثل دراســة حجـازي عبد الحميد

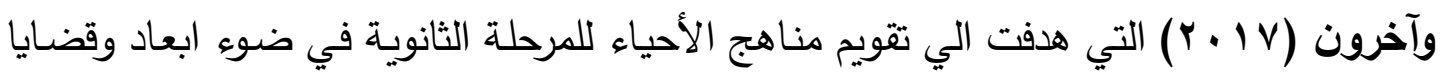
التتمية المستدامة واتبعت المنهج الوصفي التحليلي ،وتمثلت أداة الدراسة في القائمة الخاصة بأبعاد

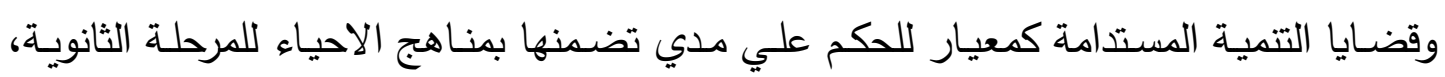

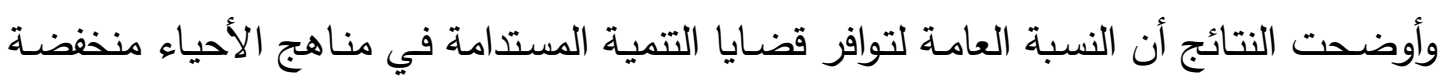
جداً، وفي ضـوء تلك النتائج تم وضـع تصسور مقترح لمنـاهج الأحيـاء في ضـوء أبعاد التنميـة المستدامة. ودراسـة موفق عبد الرضـا (Y P P التي هدفت الي تحليل محتوي كتاب الكيمياء

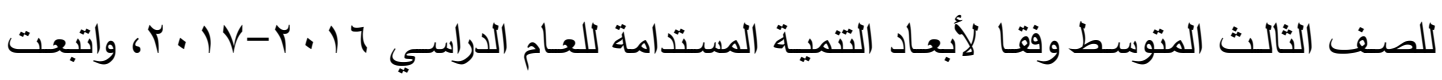

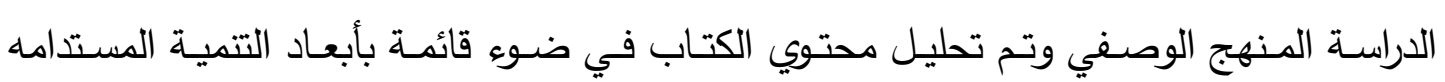

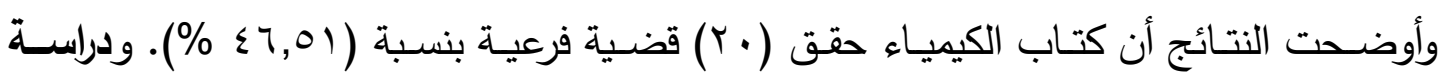
فاطمة ابراهيم (9 19 ـ r) التي هدفت الي اعداد تصور مقترح لتطوير منهج التاريخ لطلاب الصف الأول التانوي في ضوء رؤية مصر • ب • rوتعرف أثره علي تتمية قيم المواطنة لديهم واستخدمت

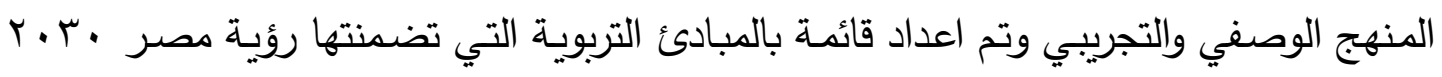
ويمكن في ضوئها تطوير منهج التاريخ وتم تحليل المحتوي في ضوئها، كما اعدت مقياس لقيم المواطنة وطبق علي عينة (ء §) طالب بالصف الأول الثانوي، وأسفرت النتائج عن وجود فرق دال احصائيا بين التطبيقين القبلي والبعدي للمقياس لصالح التطبيق البعدي وقدمت مجموعة من

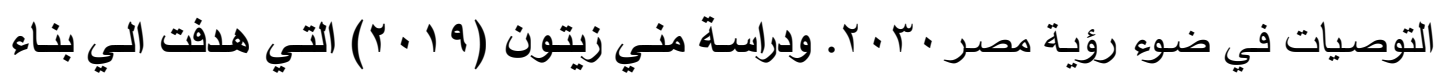

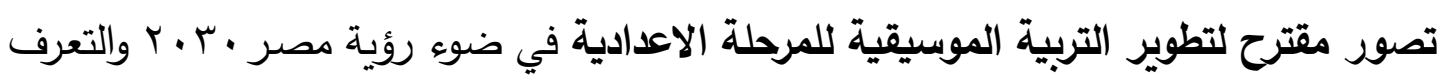
علي فاعليته من خلال تطبيق وحدة مطورة منه، وذلك لعلاج بعض القصور في تضمين مناهج

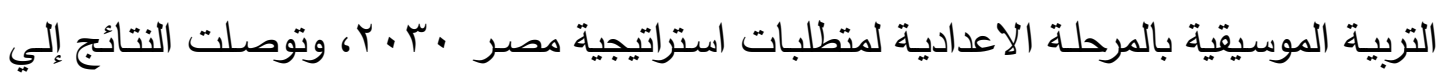


قائمة بمنطلبات التتمية المستدامة الواجب توافرها في عناصر مناهج التربية الموسيقية بالمرحلة

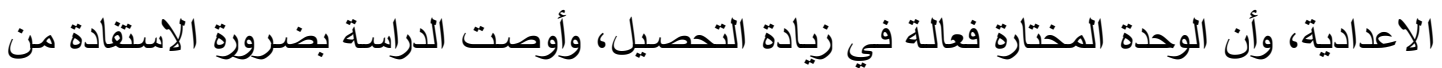
التصور المقترح ومراجعته وتطويره، وضرورة تضمين مدحتوي مناهج التربية الموسيقية الخبرات

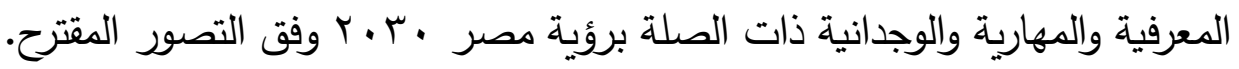

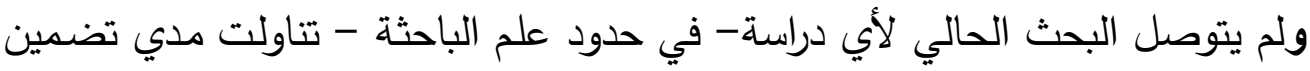

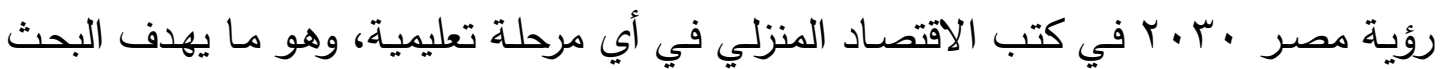
الحالي لدراسته في كتاب الاقتصاد المنزلي للصف الأول الثانوي الأزهري.
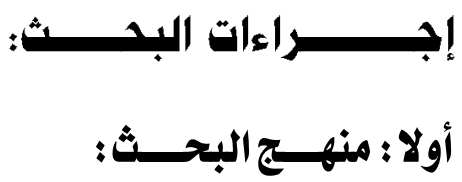

× تم استخدام اسلوب تحليل المحتوي وهو أحد أساليب المنهج الوصفي، وذلك لمناسبة هذا

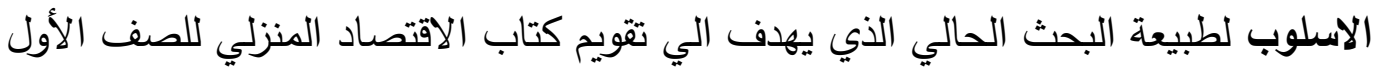

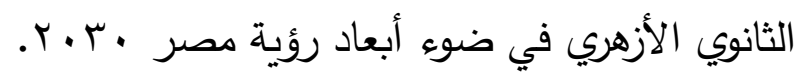

\section{ثانيا : عينـــة البحســث}

تكونت عينـة البحث مـن كتاب الاقتصـاد المنزلبي المقررعلي طالبـات الصف الأول

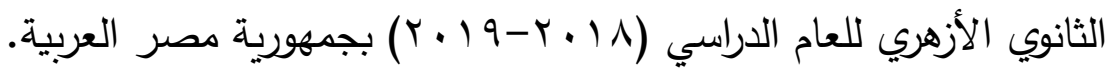
جلدول (1) وصف كتاب الاقتصاد المنزلي المقرر علي طالبات الصف الأول الثانوي الأزهري

\begin{tabular}{|c|c|c|c|c|}
\hline عدد الفقرات & علدد الصفحات & عدد الدروس & علد الوحدات & الصف \\
\hline vq. & IVY & ro & 0 & الأول الثانوي \\
\hline
\end{tabular}

ويتضح من جدول ( () أن عدد الصفحات التي تم تحليل محتواها ( VVV) صفحة.

\section{ثالثاُ : أداة البحث : بطاقة تحليل المحتوي}

وقد تطلب اعداد بطاقة تحليل المحتوي : بناء قائمـة بالقضـايا الفرعية لأبعاد رؤيـة

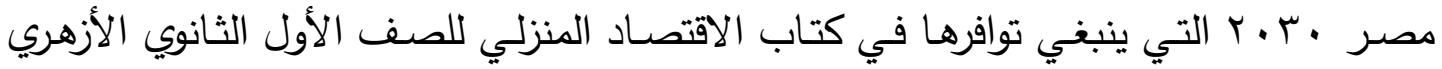
لإجراء عملية تحليل المحتوي في ضوئها وتم اعدادها وفقا للخطوات الآتية: • الدراسة التفصيلية والدقيقة لرؤية مصر • · · بأبعادها ومحاورها. 
همح الدراسات والابحاث في مجال تحليل وتطوير المقررات في ضوء الروئ المستقبلية مثل

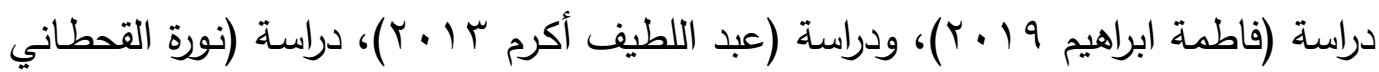

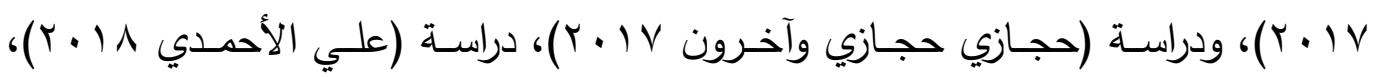

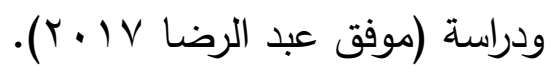

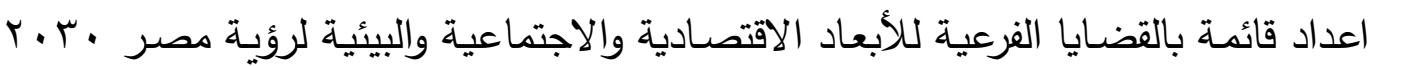
ذات الصلة بمجالات الاقتصاد المنزلي تكونت من ثلاثة أبعاد رئيسة وهي البعد الاقتصادي (تكون من کr قضية فرعية) والاجتماعي (0 ق قضية فرعية) والبيئي (·r قضية فرعية) في أربعة مجالات للاقتصـاد المنزلي التي تضمنها الكتاب وهي (ادارة مؤسسات الأسرة، الملابس والنسيج، التغذية وعلوم الأطعمة، العلاقات الأسرية). عرض القائمة علي مجموعة من السادة المحكمين في مجال المناهج وطرق التدريس لابداء

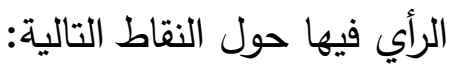

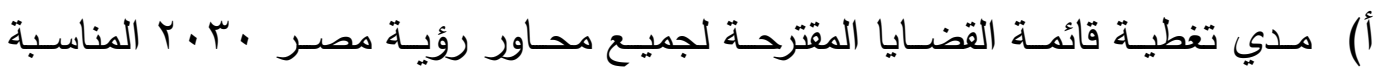
لمجالات الاقتصاد المنزلي. ب) مدي تغطية قضايا رؤيـة مصر • • ب المضمنه في كل بعد للأهداف الاستراتيجية

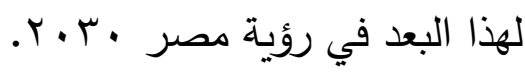
ج) مدي مناسبة القضايا لمجالات الاقتصاد المنزلي. وقد أسفر التحكيم عن حذف بعض العبارات لتكرارها أو عدم مناسبتها مع أهداف الاقتصاد المنزلي، كما تم اعادة صياغة بعض العبارات وضبطها لغويا. • في ضوء أراء السادة المحكمين تم بناء القائمة النهائية تكونت من ثلاثة أبعاد رئيسة وهي البعد الاقتصادي (تكون من اب قضية فرعيـة) والاجتماعي (اب قضية فرعيـة) والبيئي (1) 1 قضية فرعية) تم تطبيق كل منها علي حدة في أربعة مجالات للاقتصاد المنزلي التي تضمنها الكتاب وهي: (ادارة مؤسسات الأسرة ،الملابس والنسيج، التغذية وعلوم الأطعمة، العلاقات الأسرية) وتم توزيعها كما يلي: 
جلول (r) علد قضايا أبعاد رؤية مصر •r.r موزعة علي مجالات الاقتصاد المنزلي

\begin{tabular}{|c|c|c|c|c|}
\hline العلاقات الأسرية & التفذية الأطعمة & الملابس والنسيج & الأسرة وارة مؤسسات & المجال \\
\hline YI & $M$ & M & $Y_{1}$ & الاقتصادى \\
\hline M & $r$ & $M$ & rI & الاجتماعي \\
\hline 11 & 11 & IA & IA & البيئي \\
\hline 7. & 9. & 7. & 7. & المجموع الكلي \\
\hline
\end{tabular}

وبذلك أصبحت القائمة جاهزة بالصيغة النهائية أي حققت شروط الصدق الظاهري.

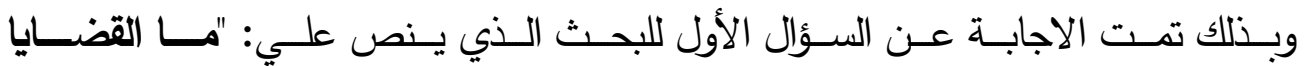

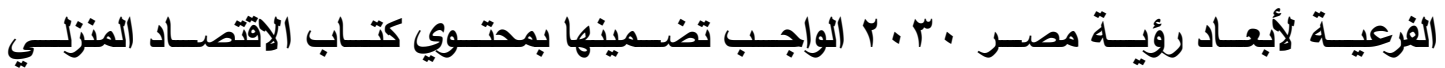
للصف الأول الثانوي الأزهري"؟

وللاجابة عن السؤال الثاني الذي ينص علي "ما مدي تضمين قضايا أبعاد رؤيسة مصر

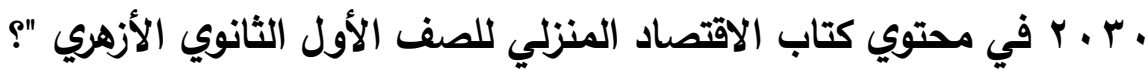
تم اعداد بطاقة تحليل المحتوي وفقـا للخطوات الآتيـة: بعد الاطـلاع علي الأدبيات والدراسات التي اهتمت بتحليل المحتوي مثل . (Williams 1983)، (رشدي طعيمة 9 . . ؟)، •Wang 1998)، (Mayring 2014)، (Neuendorf 2016) هـ تحديد الهدف مـن بطاقة التحليـل: وهو الحكم علي مدي تضمين محتوي كتاب الاقتصـاد المنزلي بالصف الأول الثانوي الأزهري بمصر للقضايا الفرعية لأبعاد رؤية مصر • ب. • . .

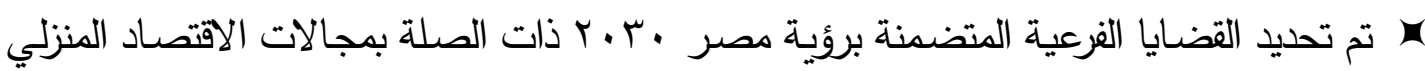

حيث تم اعداد القائمة وعرضها علي المحكمين وتم صياغتها في الصورة النهائية (كما سبق). تحديد عينـة التحليل: شملت جميع الموضوعات الواردة بكتاب الاقتصـاد المنزلي للصف الأول

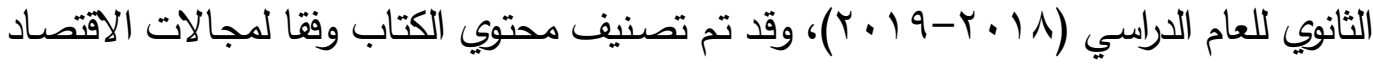
المنزلي (ادارة مؤسسـات الأسـرة والطفولتة، الملابس والنسيج، التغذيـة وعلوم الأطعدـة، العلاقات الأسرية) حتي يتسني للباحثة تحليلها في ضوء قضايا رؤية مصر .ب •r. تحديد مصادر اشتقاق ومكونات بطاقة التحليل: • تحليـ فئات التحليل: اعتبر البحث الحـالي كل قضية من قضـايا أبعاد رؤيـة مصر • r • r- التي تم صياغتها في صورة عبارات بالقائهـة- فئة يتم في ضوئها التحليل. 


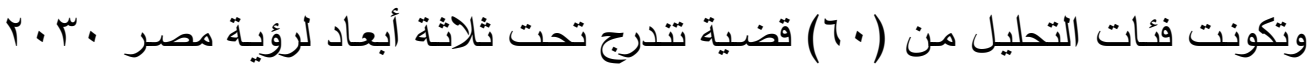

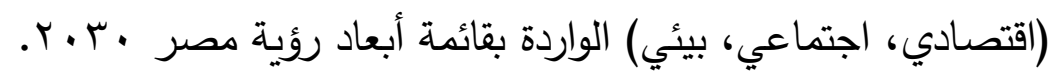

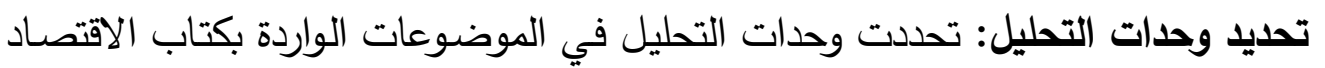

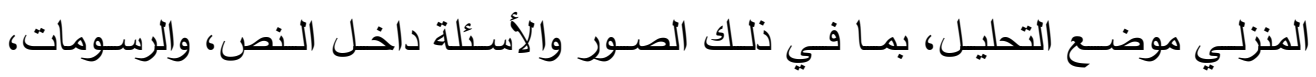

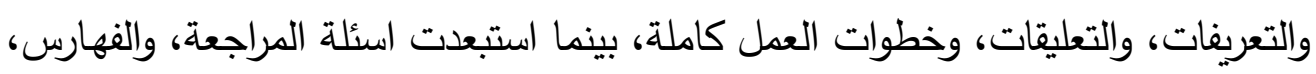

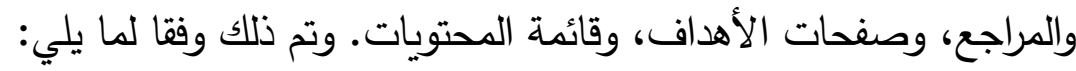
وحدة التسجيل: وهي أصغر جزء من المحتوي المحلل يتت عن طريقها إحصاء ما والمات

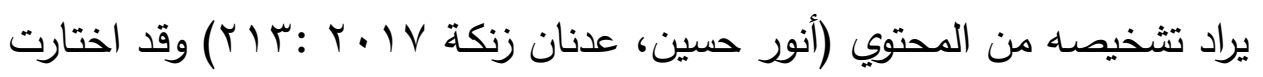

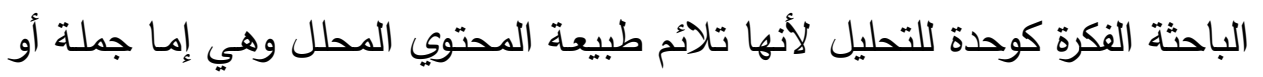
أكثر تدور حول مفهوم معين أو فكرة تدور حول مفهوم معين أو قضية محددة الأنيا

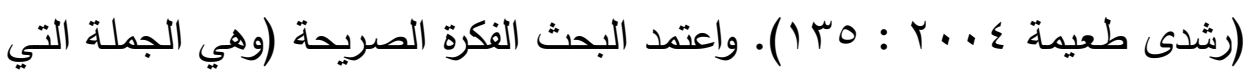

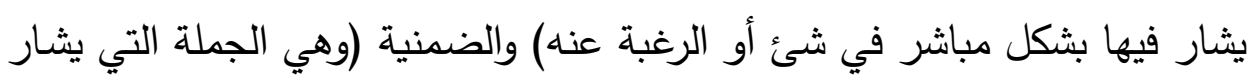

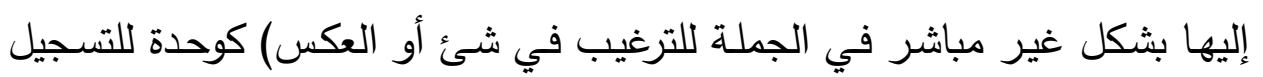
باعتبار كتاب الاقتصاد المنزلي كتاب علمي ذا طبيعة فئية فئية واجتماعية.

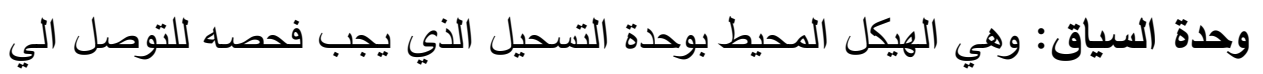
تثخيص وحدة التسجيل وهي عادة الفقرة او الموضوع الذي توجد به الفكرة (أنور

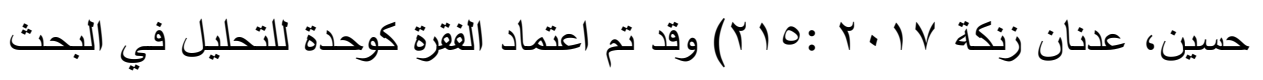

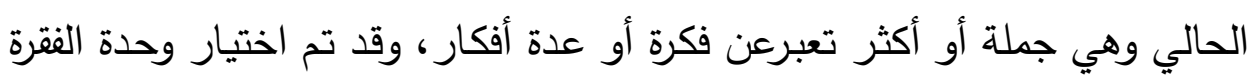

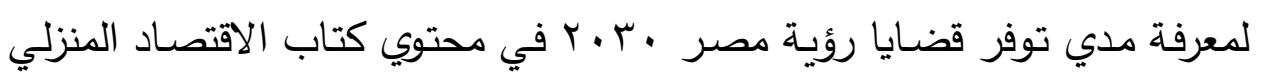
للصف الاول الثانوي الأزهري، حيث إن وحدة الفقرة مناسبة لتحقيق أهداف البحث نظرا لمناسباتها لمحتوي الاقتصاد المنزلي وشيوع استخدامها في تدريسه.

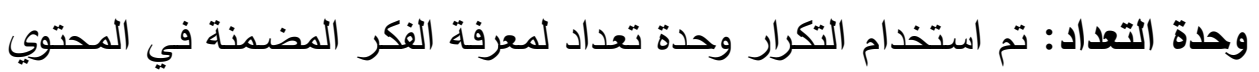

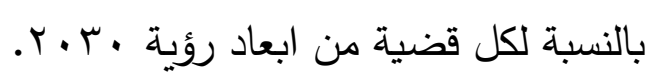
الصورة الأولية لأداة التحليل: أعدت الصورة الأولية لأداة التحليل بحيث شملت: صفحة

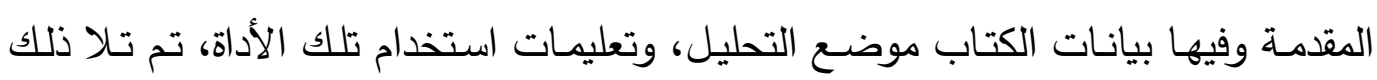

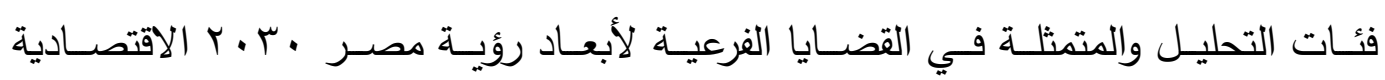

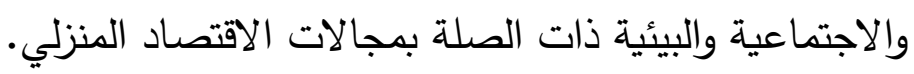


א تم وضـع مقياس متدرج للتحليل في مستويين (يتـاول - لا يتناول) لتحديد مدي تتاول

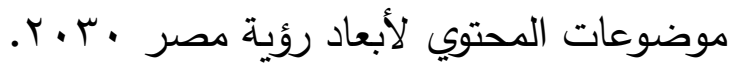

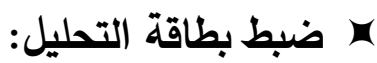

الصدق: تم عرض بطاقة التحليل علي عدد من المحكمين للتحقق من الصدق الظاهري وعددهم ثمانية محكمين في مجال مناهج وطرق التدريس الاقتصاد المنزلي، وتم الاشارة

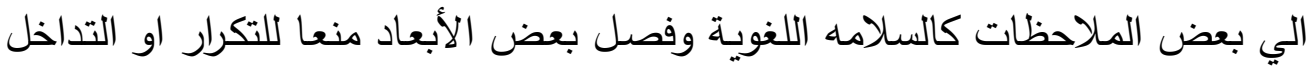
وتم اجراء التعديلات التي اشاروا اليها.

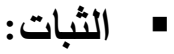

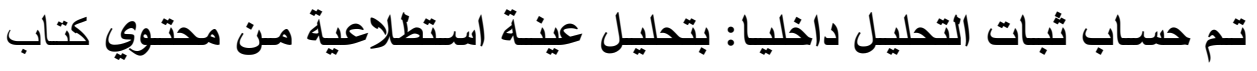

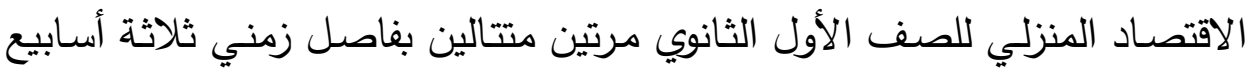

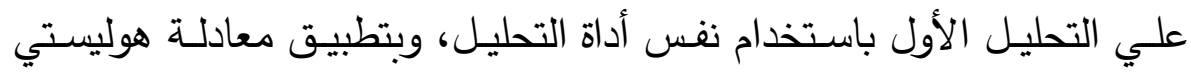

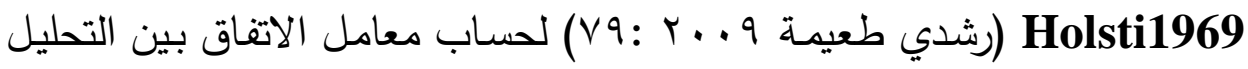

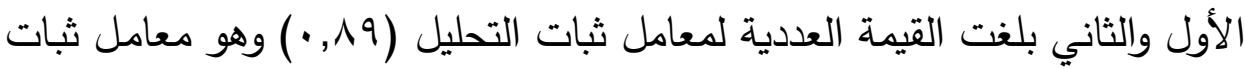
مرتفع مما يشير الي ثبات التحليل.

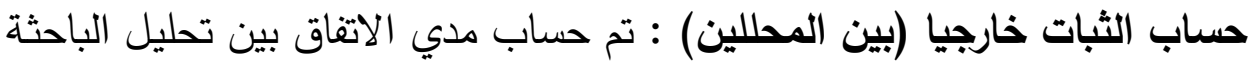

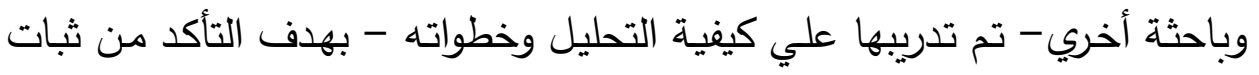

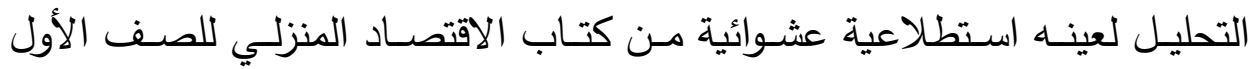

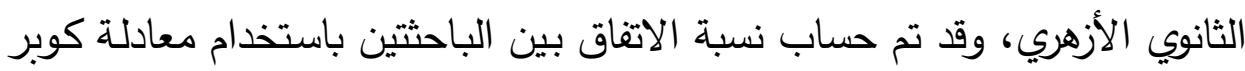

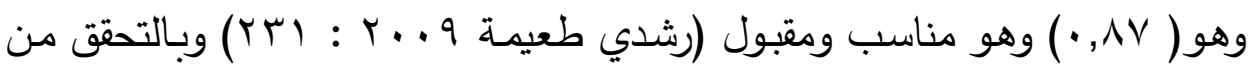

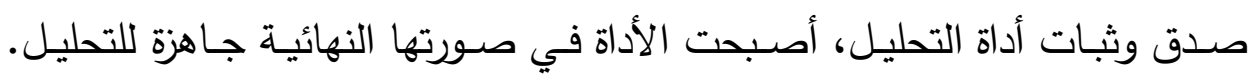

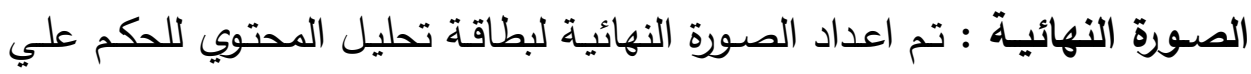

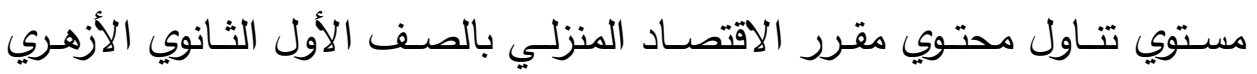

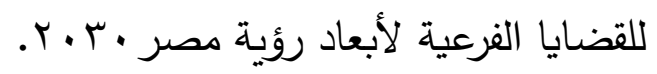

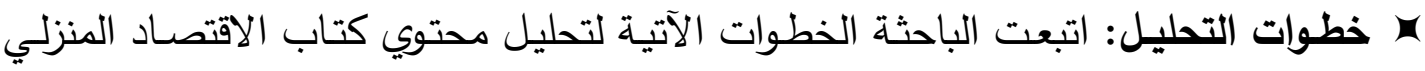
المقرر علي طالبات الصف الاول الثانوي الأزهري:

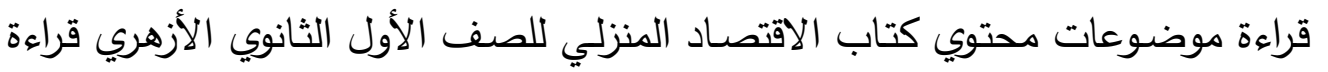

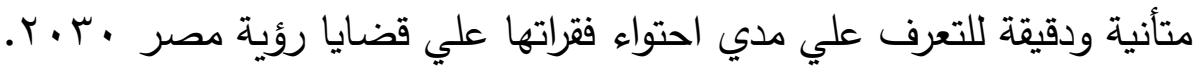


قسمت موضوعات الاقتصـاد المنزلي الي فقرات حيث تم اعتماد الفقرة وحدة لتحليل

الكتاب، كما تم تحديد العبارات التي تحوي علي فكرة أي تطبيق وحدة التسجيل. تحليل جميع الموضوعات في كتاب الاقتصاد المنزلي بالصف الاول الثابدي الثانوى الأزهري.

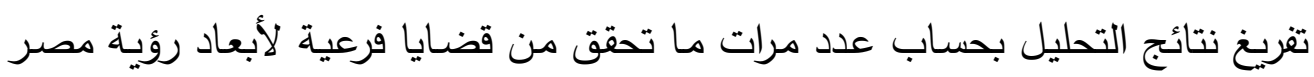

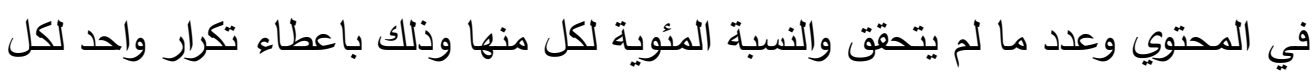

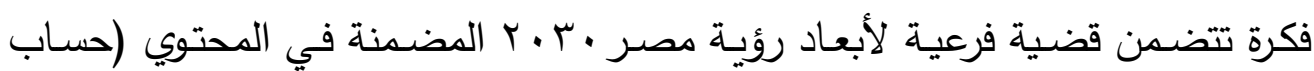

$$
\text { التكرارات والنسب المئوية لكل قضية). }
$$

( صدق التحليل: والذي يقصد به مدي تحقيق الأداة للغرض الذي أعدت من أجله، وللتأكد

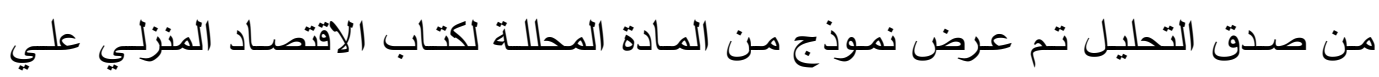
استاذتين في مناهج وطرق تدريس الاقتصاد المنزلي وقد اجمعتا علي صلاحية التحليل.

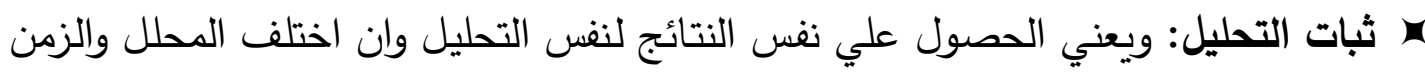

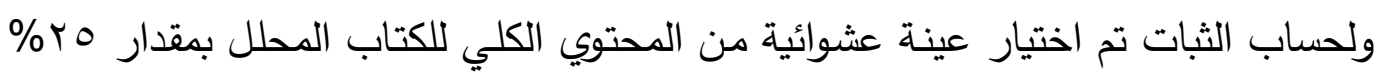

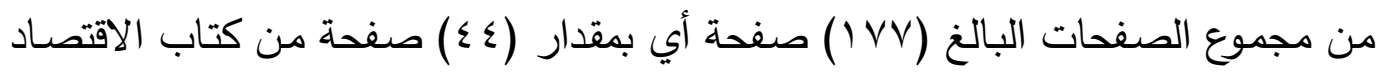

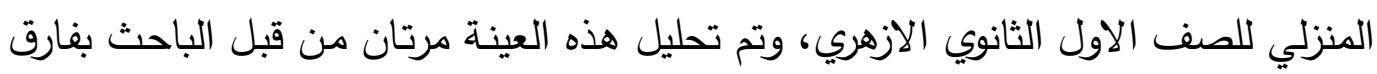

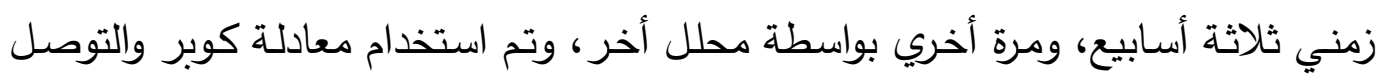
الي معاملات اتفاق بلغت (؟ 9\%، 01\%) علي التوالي. وهي معاملات مناسبة.

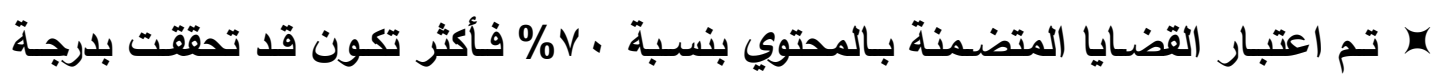

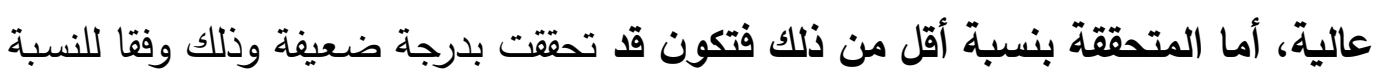
المحكية التي اقترحها معظم المحكمين، وقد تم اعداد جداول لرصد التحليل، ثم تفريغ جداول الرصد واستخراج نتائج التحليل.

بعد تحليل محتوي كتاب الاقتصـاد المنزلي للصف الأول الثانوي الأزهري بحسـاب

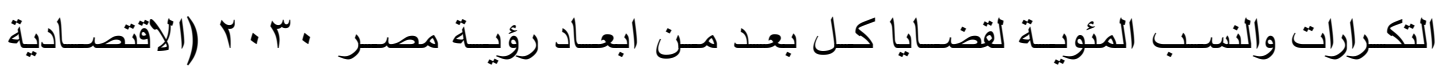

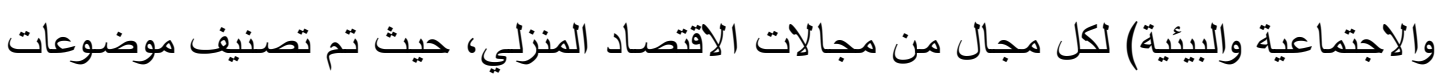

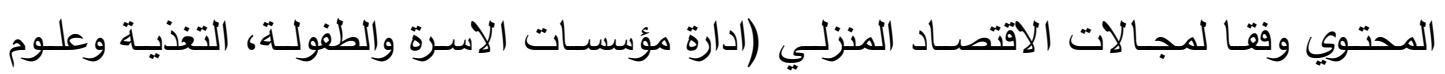
الأطعمة، الملابس والنسيج، العلاقات الأسرية) ويتضح ذلك مفتصلا الاتل فيما يلي: 


\section{مجال ادارة مؤسسات الأسرة والطفولة}

\section{أولاً: قضايا البعد الاقتصادي الرؤية مصر • بر ·H في مجال ادارة مؤسسات الأسرة والطلفولة.}

تم تحليل محتوي كتاب الاقتصاد المنزلي لطالبات الصف الاول الثانوي الأزهري (مجال

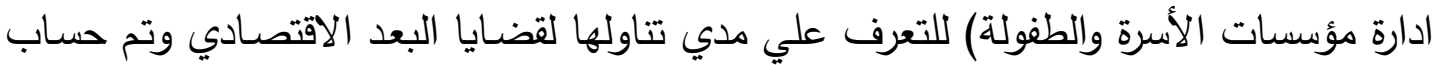
التكرارات والنسب المئوية لتلك القضايا ويوضح الجدول (r) ذلك. جلدول (ץ) التكرارات والنسب المئوية لقضايا البعد الاقتصادي لرؤية مصر • •r المحتوي كتاب الاقتصاد المنزلي

تلصف الأول الثانوي الأزهري في مجال ادارة مؤسسات الأسرة والطفولة

\begin{tabular}{|c|c|c|c|c|c|c|}
\hline المئوية & المتضايا & الترتيب & المئوية & التكرارات & 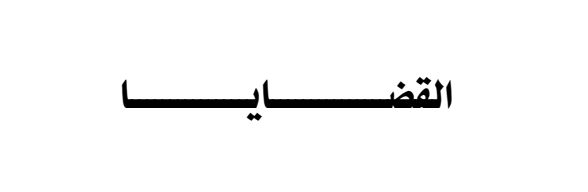 & هـ \\
\hline \multirow{22}{*}{$\% 97,7$} & \multirow{22}{*}{$1 \xi$} & 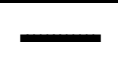 & - & - & التوسع في (الصناعة والتجارةوالزراعة) المستدامة & 1 \\
\hline & & 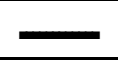 & - & $\longrightarrow$ & المحافظة علي المناطق السياحية & $r$ \\
\hline & & 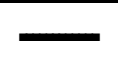 & - & $\longrightarrow$ & تشجيع السياحة الداخلية & $r$ \\
\hline & & 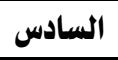 & $\varepsilon$ & r & احتراهروتقدير العمل اليدوي & $\varepsilon$ \\
\hline & & $\longrightarrow$ & $\longrightarrow$ & - & تفضيل المنتج المحلي عن المستورد & 0 \\
\hline & & - & $\longrightarrow$ & $\longrightarrow$ & الحد من التفاوت في الدخل & 9 \\
\hline & & 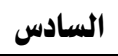 & $\varepsilon$ & r & تحقيق الأمن الفذائي & $\checkmark$ \\
\hline & & الخامس & 1 & $r$ & الاكتفاء الذاتي وخاصة الأسر الريفية & $\wedge$ \\
\hline & & 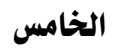 & 1 & r & ترشيد أنماط الانتاجوالاستهلاك & 9 \\
\hline & & 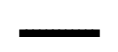 & - & - & تحسين نوعية المراقق العامة & 1. \\
\hline & & $\longrightarrow$ & $\wedge$ & $\xi$ & التصرف في حدود الامكانات المتاحة & 11 \\
\hline & & 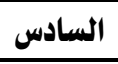 & $\xi$ & r & الشاركة في القرارات الأسرية الهامة وفي الميزانية & ir \\
\hline & & 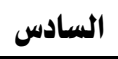 & $\xi$ & $r$ & ايجاد فرص جلديلة لحل مشكلة البطالة & ir \\
\hline & & السادس & $\xi$ & $r$ & ادخال التكنولوجيا في جميح المجالات & is \\
\hline & & 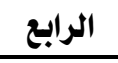 & $\wedge$ & $\xi$ & تشجيع المشروعات الصغيرة & 10 \\
\hline & & 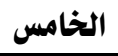 & 7 & $r$ & الثروات الطبيعيةوطرق المحافظة عليها & 17 \\
\hline & & 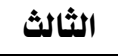 & ir & 7 & حسن استخلام الموارد المتاحه & iv \\
\hline & & 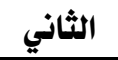 & $1 \xi$ & 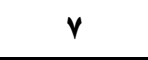 & تطبيق الاسلوب العلمي في الأدراة & in \\
\hline & & الأول & 17 & $\wedge$ & العلاقة بين اقتصاديات الأسرة وتقدم المجتمع & 19 \\
\hline & & الاخير & $r$ & 1 & تحقيق مبلأ الشفافية والمساءلة & r. \\
\hline & & الاخير & $r$ & 1 & التجديل والابتكار & $r$ \\
\hline & & & $1 .$. & 0. & المجموع & \\
\hline
\end{tabular}


يتضح من جدول (r) أن عدد قضـايا البعد الاقتصـادي لرؤيسة مصر • • • في كتاب

الاقتصاد المنزلي المقرر علي الصف الأول بالمرحلة الثانويـة الأزهريـة بلغ (ع () قضية بنسبة (7, 7 7 \% \%). ويعد مستوي تضمين قضايا البعد الاقتصادي في محتوي الكتاب أقل من النسبة

$$
\text { المحكية المتقق عليها في البحث الحالي وهي ( • \%). }
$$

كمـا يتضــح مـن جـدول (r) أن قضـية "العلاقـة بـين اقتصــاديات الأســرة وتقـدم

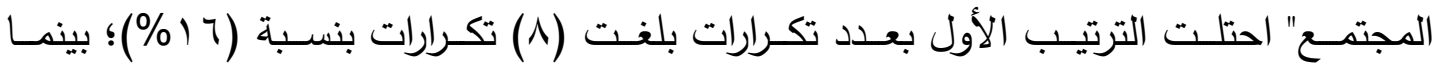

احتـل الترتيـب الثـاني قضـية "تطبيـق الاسـلوب العلمـي فـي الادارة" بعـدد تكـرارات بلغـــ

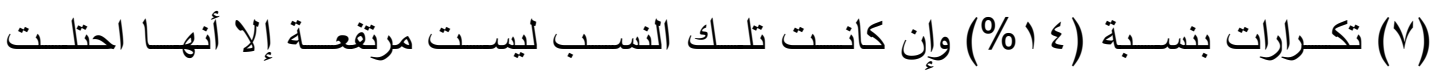

الترتيـب الأول والثـاني؛ وقـــ يرجـع ذلــك لطبيعــة مجـال ادارة مؤسســات الأسـرة والطفولــة حيـث ترتكـز الدراسـة حـول ذلـك وبالتـالي تـم تضـمين تلـك القضــايا فـي المحتـوي بصـورة أكبـر ؛ وكـان أدناهـا قضـية "تحقيـق مبـدأ الثـفافية والمســاءلة"، والتـي لابـــــــن تضـمينها

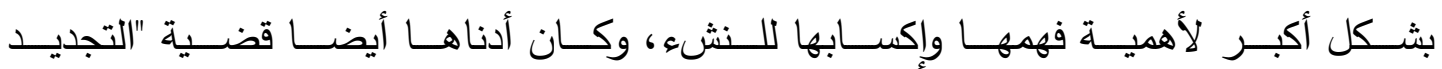
والابتكـار " بعـدد تكـرارات ( () بنسـبة (r\%\%)، وإن كـان ضـعف تضـمين تلك القضـية غيـر متوقع حيـث المجـال متعـدد الفـروع ولـه بـاع كبيـر في اكسـاب الطالبـات مهـارات التجديـد والابتكــار فـي اتجاهـات عديـدة كتنسـيق الـديكور والزهــور وادارة الاســرة والتعامـل مــع مشكلات الطفولة بابتكارية وتنوع، كما يتضح وجود سبعة قضايا غير متضمنة.

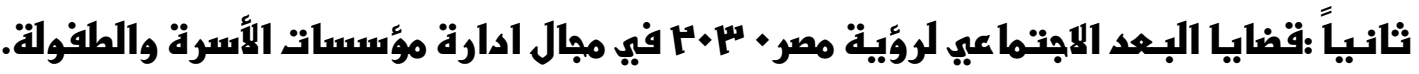

تم تحليـل محتوي كتـاب الاقتصـاد المنزلي للصف الأول بالمرحلـة الثانويـة الأزهريـة (مجال ادارة مؤسسات الأسرة والطفولة) للتعرف علي مدي تتاولها لقضايا البعد الاجتماعي تم حساب التكرارات والنسب المئوية لتلك القضايا ويوضح الجدول (ع) ذلك. 
جلول (؟) التكرارات والنسب المئوية لقضايا البعد الاجتماعي لرؤية مصر •r ·r لمحتوي كتاب الاقتصاد المنزلي

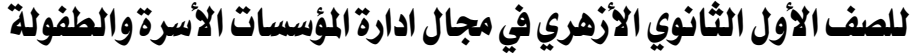

\begin{tabular}{|c|c|c|c|c|c|c|}
\hline المئوبة النسة & الترتيب & الثقضابا & المئوية & التثكرارات & 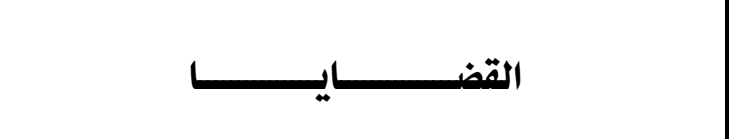 & هـ \\
\hline \multirow{22}{*}{$\%$ \%I, §V } & - & \multirow{21}{*}{$1 \cdot$} & - & - & | احترام حقوق الانسان. & 1 \\
\hline & - & & - & - & |حترام الأنظمة والتشريعات والقوانين. & $r$ \\
\hline & - & & - & - & |تحسين نوعية الحياة فى المناطق الفقيرة. & $r$ \\
\hline & - & & - & - & |المشاركة الفاعلة فى الحياة السياسية. & $\xi$ \\
\hline & الثالث & & 7,7 & 1 & |تعزيز حب الوطن والانتماي له. . & 0 \\
\hline & 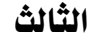 & & 7,7 & 1 & تحقيق الساواةوالعدالة في توزيع الموارد بين الأجيال. & 7 \\
\hline & الثالث & & 7,7 & 1 & دعم دور المرأة فى جميع المجالات. & 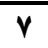 \\
\hline & الأول & & Yq, १Y & $\varepsilon$ & |المحافظة علىي الممتلكات العامة والخاصة. & $\wedge$ \\
\hline & الثالث & & 7,7 & 1 & |تقدير العمل التطوعي والمشاركة فيه. & 9 \\
\hline & & & - & - & |التصلي للشائعات الموجهة ضل الوطن ومؤسساته . & 1. \\
\hline & الثاني & & Ir, rr & $r$ & |تلريب الطالبات علي التفكير السليم & 11 \\
\hline & & & - & - & النظافة ودورها في المحافظة علىي الصحة. & ir \\
\hline & & & - & - & الأغذية الفاسلة وأثر ها علي صحة الانسان. & ir \\
\hline & الثالث & & 7,7 & 1 & استخلاه التقنيات الحليثة في حفظ وتخزين المنتجات الغذائية. & 18 \\
\hline & الثاني & & Ir, rr & $r$ & تتعزيز القيه الأخلاقية التي تهذب الطالبة وتقوه المجتمع. & 10 \\
\hline & - & & 一 & - & |التطعيم ضل الأمراض. & 17 \\
\hline & 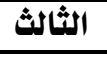 & & 7,7 & 1 & |الحرص على طلب العلم والتعلم الذاتي المستمر. & iv \\
\hline & - & & - & - & التوعية بأهمية تنظيه الأسرة. & M \\
\hline & - & & - & - & |تجنب العنف والعمل علي تقبل الآخر & 19 \\
\hline & الأخير & & 7,7 & 1 & |تقدير الحياة الأسرية. & $r \cdot$ \\
\hline & - & & - & 二 & الحفاظ علي الهوية والعادات والتقاليد & YI \\
\hline & & & $\% 1$. & 10 & المجموع & \\
\hline
\end{tabular}

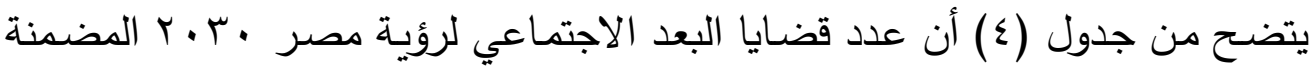
في كتاب الاقتصـاد المنزلي للصف الأول الثانوي الأزهري في مجال ادارة مؤسسـات الأسـرة والطفولة بلغ ( • () تكرارات، وبنسبة (V V , اس \%) وهي نسبة ضعيفة في ضوء النسبة المحكية، ولأن مجال ادارة مؤسسات الأسرة والطفولة يغلب عليه الطابع الاجتماعي فإن تضمين قضـايا البعد الاجتماعي يعد أمر يسير مع أهميته للطالبات لمساعدتهن علي تكوين اتجاهات ايجابية في هذا الجانب بما يعود عليهن وعلي المجتمع بالنفع. كما يتضـح من الجدول (ع) أن قضية "المحافظة علبي الممتلكات العامـة والخاصـة" الترتيب الأول بعدد تكرارات بلغت (ع) تكرارات بنسبة (7,7, r \% \%)؛ بينما احتل الترتيب الثاني 
قضيتي "تدريب الطالبات علي التفكير السليم"، و"تعزيز القيم الأخلاقية التي تهذب الطالبة وتقوِم

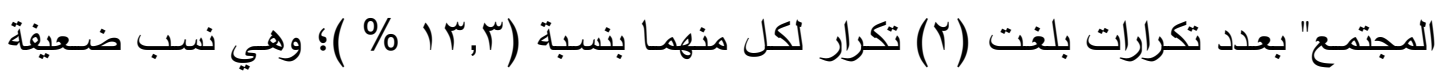
ايضـا مـع أهميتها ،وحصلت سبعة قضـايا علي تكرار ( (1) بنسبة (7,7\%) وهي قضـايا مهمـة جدا ويمكن تضمينها في المجال، كما يتضح أنه يوجد احدي عشره قضية غير متضمنة ولا تقل أهمية عن باقي القضايا.

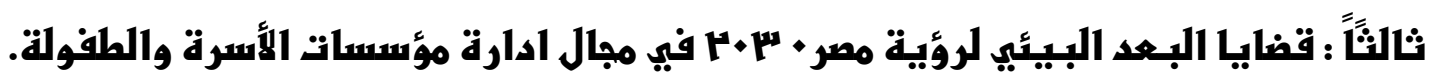

تم تحليل محتوي كتاب الاقتصـاد المنزلي للصف الأول الثانوي الأزهري (مجال ادارة

مؤسسات الأسرة والطفولة) للتعرف علي مدي تضمنه لقضـايا البعد البيئي تم حساب التكرارات

$$
\text { والنسب المئوية لتلك القضايا ويوضح الجدول (0) ذلك موائ }
$$

جدول (0) التكرارات والنسب المئوية لقضايا البعد البيئي لرؤية مصر •r ·r المتضمنة بمحتوي كتاب الاقتصاد

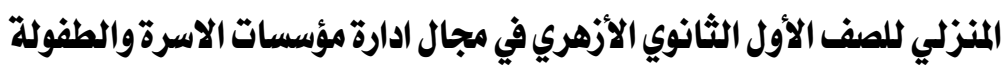

\begin{tabular}{|c|c|c|c|c|c|c|}
\hline المئوية & المتضمنة القضاد & | الترتيب| & المئوية & 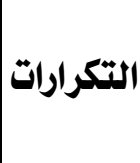 & 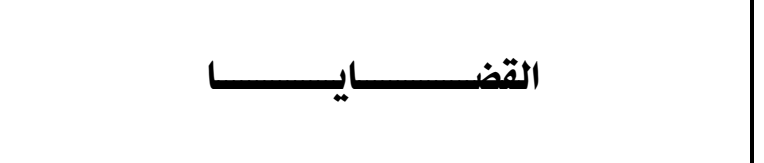 & هـ \\
\hline \multirow{19}{*}{$\% .0}$. & \multirow{19}{*}{9} & 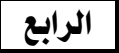 & $0, \wedge \wedge$ & 1 & |الوعى بأهمية البيئة والمحافظة عليها. & 1 \\
\hline & & الثالث & $11, \vee 19$ & $r$ & |الوعي بأشكال التلوث المختلفة & $r$ \\
\hline & & $\longrightarrow$ & - & - & |ترشيد استهلاك المياه العذلبة. & $r$ \\
\hline & & 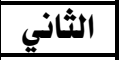 & $1 v, 70$ & $r$ & ترشيد استهلاك الموارد غير المتجلدة. & $\xi$ \\
\hline & & - & - & 二 & |التوجه نحو الطاقة النظيفة صليقة البيئة. & 0 \\
\hline & & - & - & - & |زيادة مساحة الرقعة الخضراء. & 7 \\
\hline & & - & - & - & | استخدام المصابيح الموفرة للطاقة. & $\checkmark$ \\
\hline & & 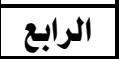 & $0,1 \wedge$ & 1 & | اعادة تدوير المخلفات. & $\Lambda$ \\
\hline & & الثالث & $11, \mathrm{Vq}$ & $r$ & علدم الاسراف فى الموارد بصفة عامة. & 9 \\
\hline & & - & - & - & |دور القوانيز والتشريعات فى حماية البيئة. & $1 \cdot$ \\
\hline & & - & - & - & الأنشطة الملدرسية ودورها فى نظافة وحماية البيئة. & 11 \\
\hline & & - & $=$ & 二 & تنتية مياه الشرب والحفاظعليها. & ir \\
\hline & & 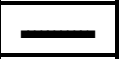 & - & - & التوعية بتنظير عملية الصيدوالحفاظعلي الكائنات البرية البحرية. & IT \\
\hline & & - & - & - & محاربة التصحر والجفاف وإزالة الغابات. & 18 \\
\hline & & 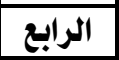 & $0, \wedge \wedge$ & 1 & |تنمية الثروة الحيوانية والنباتية. & 10 \\
\hline & & 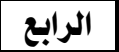 & $0, \wedge \wedge$ & 1 & |توفير الخدمات الللائقة وتعميهر الكهرباء. & 17 \\
\hline & & الثالث & $11, \vee 7$ & $r$ & |الأمن في مجال العمل & iv \\
\hline & & الأول & rr,or & $\varepsilon$ & |تنمية القيه الجمالية & 11 \\
\hline & & & $1 \cdots$ & iv & |المجموع & \\
\hline
\end{tabular}


يتضح من جدول (0) أن عدد قضايا البعد الاجتماعي لرؤية مصر •r.r المضمنة في محتوي كتاب الاقتصاد المنزلي لطالبات الصف الأول الثانوي الأزهري في مجال ادارة مؤسسات الأسرة والطفولة بلغ (9) تكرارات، وبنسبة ( •0\%) وهي نسبة أقل من النسبة المحكية للبحث الحالي، وتعد ضـعيفة بالنسبة لاحتياجـات المجتمع في ظل الدعوات لتحقيق متطلبات التتميـة المستدامة خاصة في الموارد البيئية المتاحه في الوقت الحالي وغير المتجددة منها بشكل اكبر . ويتضـح من الجدول (0) أن قضية "تتميـة القيم الجمالية احتلت" الترتيب الأول بعدد

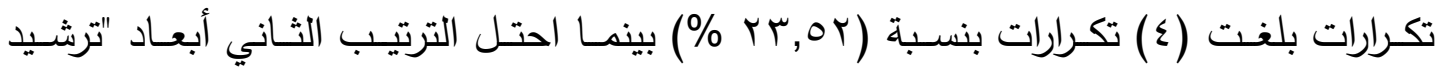
استهلاك الموارد غير المتجددة" و "الوعي بأشكال التلوث المختلفة" و "عدم الاسراف فى الموارد بصففة عامـة"، والأمسن في مجـال العهل" بعدد تكرارات بلغت (؟) تكرار لكل مـنهم بنسبة

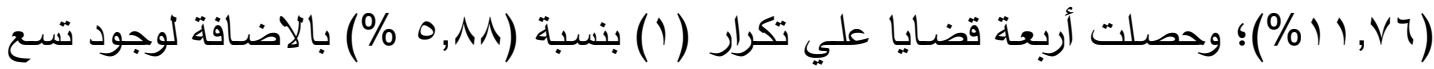
قضايا غير مضمنة في المحتوي، وعند النظر لكل قضية علي حده سواء المضمنة أو غير المضمنة نجد أن جميعها قضايا ذات أهمية ويمكن ادراجها في المجال بأشكال متعددة صراحة أو ضمنا خاصة أن المجال له شق نظري وأخر عملي ويمكن ربطهما بقضايا التتمية المستدامة بهدف اكسابها للطابات وتحقيق متطلباتها في المجتمع.

وبـنلك تمـت الاجابـة عن السؤال الذي نص علـي "مـا مدي تضمين محتوي كتاب

الاقتصاد المنزلي للصف الأول الثانوي الأزهري لقضايا الابعاد الاقتصادية والاجتماعية والبيئية لرؤية مصر • • •r في مجال (ادارة مؤسسات الأسرة والطفولة).

\section{مجسـال المــلابــسـ والنسيــجـج}

\section{رابـعاً : قضايا البعد الاقتصادي لرؤية مصر • "ر ·H في مجال الملابسر والنسيج}

تـم تحليـل محتـوي كتـاب الاقتصـاد المنزلـي للصـف الأول الثانوي الأزهـري (مجـال الملابس والنسيج) للتعرف علي مدي تناولها لقضـايا البعد الاقتصـادي تم حساب التكرارات والنسب المئوية لتلك القضايا ويوضح الجدول (†) ذلك. 
جلدول (7) التكرارات والنسب المئوية لقضايا البعد الاقتصادي لرؤية مصر •r+r بمحتوي كتاب الاقتصاد

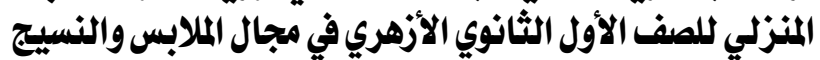

\begin{tabular}{|c|c|c|c|c|c|c|}
\hline المئوية & المتضايا & الترتيب & المئوية & التكرارات & 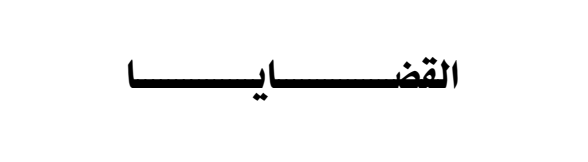 & هـ \\
\hline \multirow{22}{*}{$\%$ or, rA } & \multirow{22}{*}{11} & $=$ & - & - & التوسع في (الصناعة والتجارةوالزراعة) المستلدامة & 1 \\
\hline & & - & - & - & المحافظة علي المناطق السياحية & $r$ \\
\hline & & - & - & - & تشجيع السياحة الداخلية & $r$ \\
\hline & & 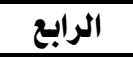 & $\Lambda, r r$ & $\varepsilon$ & احترام وتقدير العمل اليدوي & $\xi$ \\
\hline & & 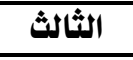 & $1 \cdot, Z Y$ & 0 & تفضيل المنتج المحلي عن المستورد & 0 \\
\hline & & - & $=$ & $=$ & الحد من التفاوت في الدخل & 7 \\
\hline & & $=$ & $=$ & $=$ & تحقيق الأمن الفذائي & 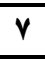 \\
\hline & & السادس & $1 \xi, \mid V$ & r & الاكتفاء الذاتي وخاصة الأسر الريفية & $\Lambda$ \\
\hline & & الثالث & $1 \cdot, \xi r$ & 0 & ترشيد أنماط الانتاجوالاستهلاك & 9 \\
\hline & & - & - & - & تحسين نوعية المراقق العامة & 1. \\
\hline & & 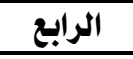 & $\Lambda, r r$ & $\xi$ & التصرف في حدود الامكانات المتاحة & 11 \\
\hline & & $=$ & $\square$ & - & المشاركة في القرارات الأسرية الهامة وفي الميزانية & ir \\
\hline & & 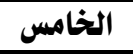 & 7, ro & $r$ & ايجاد فرص جليلة لحل مشكلة البطالة & it \\
\hline & & لخامس & 7, ro & $r$ & ادخال التكنولوجيا في جمييع المجالات & 1ई \\
\hline & & 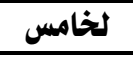 & 7, ro & $r$ & تشجيع المشروعات الصفيرة & 10 \\
\hline & & $=$ & - & $=$ & الثروات الطبيعية وطرق المحافظة & 17 \\
\hline & & الأول & $11, \mathrm{YO}$ & 9 & حسن استخلاهر الموارد المتاحه & iv \\
\hline & & الثاني & 17,77 & $\wedge$ & تطبيق الاسلوب العلمي في الأدراة & 11 \\
\hline & & $=$ & - & $=$ & العلاقة بين اقتصاديات الأسرة وتتده المجتمع & 19 \\
\hline & & $=$ & $=$ & - & تحقيق مبلأ الشفافية والمساءلة & r. \\
\hline & & السادس & $\varepsilon, 1 \mathrm{~V}$ & $r$ & التجليد والابتكار & $r$ \\
\hline & & & 1.. & $\xi \Lambda$ & المجموع & \\
\hline
\end{tabular}

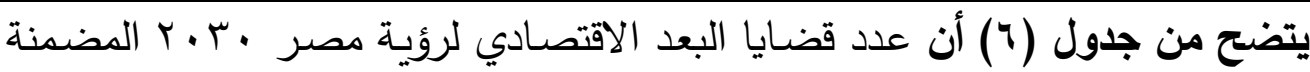

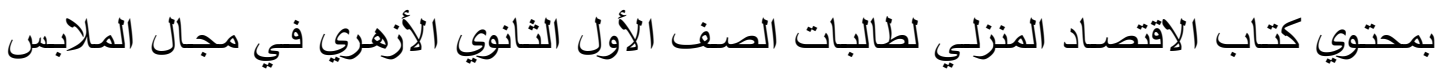

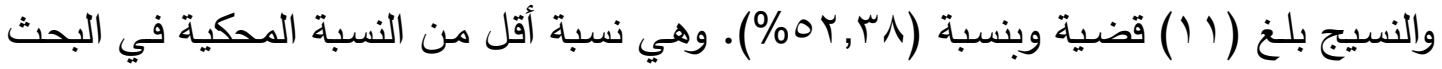
الحالي وتعد ضعيفة بالنسبة لمجال الملابس والنسيج لصلته الكبيرة بالناحية الاقتصادية للأسرة التي هي نواة المجتمع، وتدعيم محتوي كتاب الاقتصـاد المنزلي بالقضـايا الاقتصـادية في مجال

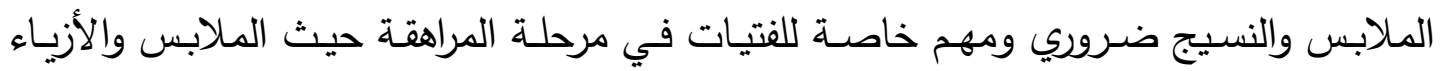
والموضة تشغل اهتمامهن ويبذل من أجلها الكثير من الأموال، وقد تزايدت في السنوات الأخيرة

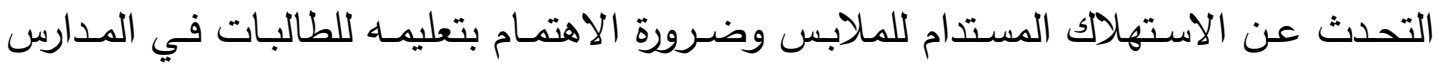

$$
\text { وتكوين اتجاهات ايجابية نحوه. }
$$


ويتضح من جدول (T) أن قضية " حسن استخدام الموارد المتاحه " احتلت الترتيب الأول

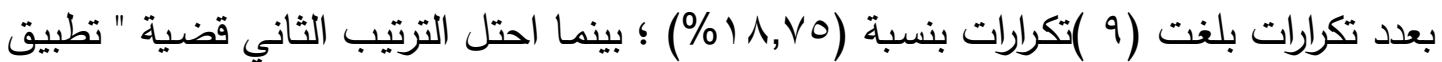

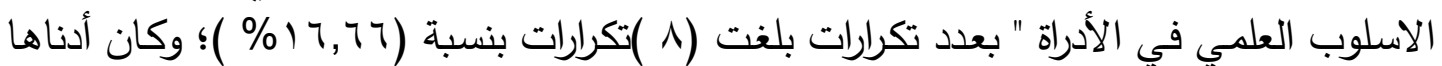

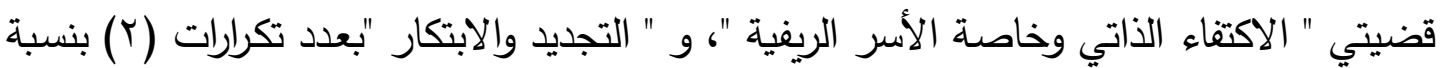
(\% \&, lV)

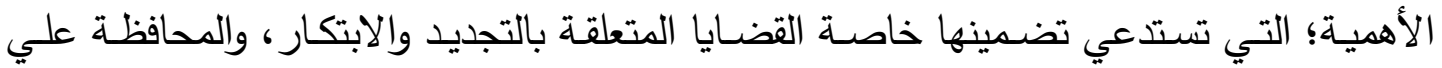
الثروات الطبيعية والمشاركة في ميزانية الأسرة ؛ نظرا لارتباطها الوثيق بمجال الملابس والنسيج وسهولة تضمين جميع القضايا في الثق العملي أو النظري للمجال.

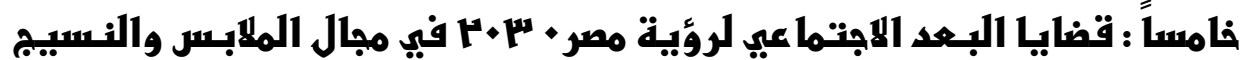

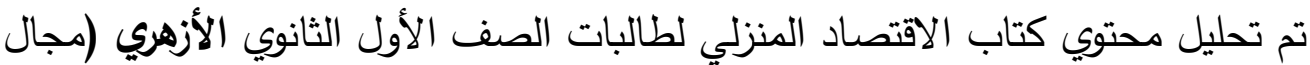

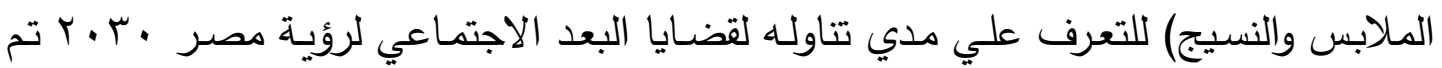

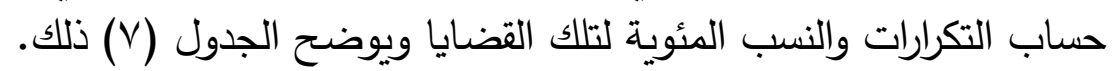

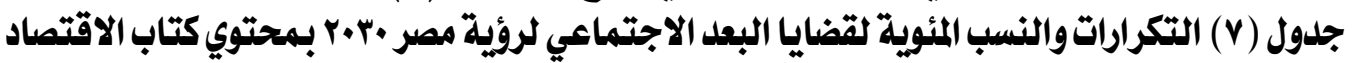

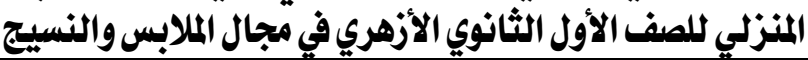

\begin{tabular}{|c|c|c|c|c|c|c|}
\hline المئوية & المتحقاية & الترتيب| & الائوية & 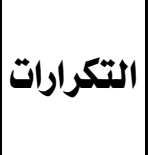 & 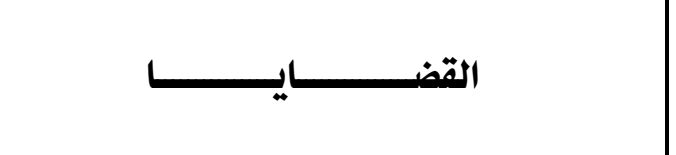 & هـ \\
\hline \multirow{21}{*}{$\% \& \vee, \eta 1$} & \multirow{21}{*}{ 1. } & الثاني & $10, \mathrm{rA}$ & 7 & | احترام حقوق الانسان. & 1 \\
\hline & & - & - & - & | احتراه الأنظمة والتشريعات والقواذين. & $r$ \\
\hline & & الأول & $r \cdot 01$ & $\wedge$ & |تحسيز نوعية الحياة في المناطق الفقيرة. & $r$ \\
\hline & & $\overline{-}$ & - & - & | المشاركة الفاعلة فى الحياة السياسية. & $\xi$ \\
\hline & & الخامس & r,07 & 1 & |تعزيز حب الوطنوالانتماء له. & 0 \\
\hline & & $\overline{-}$ & - & - & |تحقيق المساواة والعدالة في توزيع الموارد بين الأجيال. & 7 \\
\hline & & الثالث & $1 \cdot, Y q$ & $\xi$ & |دعمر دور المرأة فى جميع المجالات. & $\mathrm{v}$ \\
\hline & & 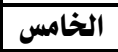 & $r, 07$ & 1 & | المحافظة على الممتلكات العامة والخاصة. & $\Lambda$ \\
\hline & & 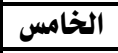 & r,07 & $T$ & |تقلير العمل التطوعي والمشاركة فيه. & 9 \\
\hline & & - & - & - & ا التصدي للشائعات الموجهه ضد الوطن ومؤسساته. & 1. \\
\hline & & 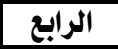 & 0,14 & $\frac{T}{r}$ & |تلدريب الطالبات علي التفكير السليم & 11 \\
\hline & & $\overline{-}$ & - & - & | النظاقة ودورها في المحافظة علىي الصحة. & Tr \\
\hline & & - & $\overline{-}$ & - & |الأغلية الفاسلة أتثرها علي صحة الانسان. & $\overline{T r}$ \\
\hline & & - & $\overline{-}$ & $\overline{-}$ & استخدار التقنيات الحليثة في حفظ وتخزين المنتجات الفذائية. & Iई \\
\hline & & 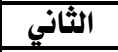 & $\overline{10, \Gamma \Lambda}$ & 7 & تتعزيز القيه الأخلاقية التي تهلب الطالبة وتقوه المجتمع. & 10 \\
\hline & & - & - & - & التطعير ضل الأمراض. & 17 \\
\hline & & الأول & $r \cdot 01$ & $\Lambda$ & الحرص على طلب العله والتعلم الذاتي المستمر. & iv \\
\hline & & 二 & - & - & |التوعية بأهمية تنظيه الأسرة. & 11 \\
\hline & & - & 二 & - & |تجنب العنف والعمل علي تقبل الآخر & 19 \\
\hline & & - & - & - & |تقدير الحياة الأسرية. & r. \\
\hline & & 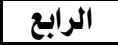 & 0,14 & $r$ & | الحفاظعلي الهوية والعادات والتقاليد & rI \\
\hline & & & 10 & rq & |المجموع & \\
\hline
\end{tabular}


يتضح من جدول (V) أن عدد قضايا البعد الاجتماعي لرؤية مصر ·r •r المضمنة في محتوي كتاب الاقتصاد المنزلي لطالبات الصف الأول الثانوي الأزهري في مجال الملابس والنسيج بلغ ( • () تكرارات وبنسبة ( (اT, § ) وهي نسبة ضعيفة فـلا شك أن للملابس دورا اجتماعيا يؤثر في الآخرين ويعطي انطباعـا عن الفرد وقد يحدد دوره أو مهنته وبذلك فإن تضمين قضايا البعد الاجتماعي في مجال الملبس أمر ذا أهمية ويمكن تتفيذه لتحقيق أهداف المجتمع ومتطلبات تتميته من خلال مناهج التعليم التي يعرض محتواها الكتاب المدرسي. كما اتضـح من جدول (V) أن قضيتي " تحسين نوعية الحياة فى المناطق الفقيرة.."، والحرص على طلب العلم والتعلم الذاتي المستمر . " اخذتا الترتيب الأول بعدد تكرارات بلغت

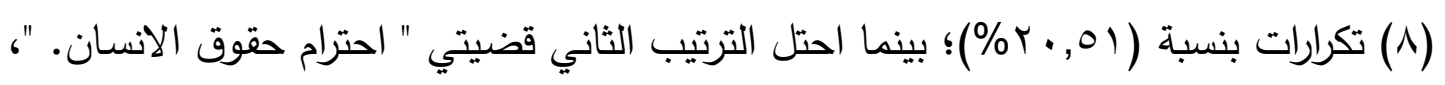
و" تعزيز القيم الأخلاقية التي تهذب الطالبة وتقوّمِ الهتمع." بعدد تكرارات بلغت (؟) تكرار

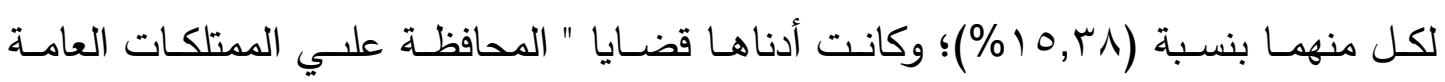
والخاصـة."، والمحافظـة على الممتلكات العامـة والخاصـة، وتقدير العمل التطوعي والمشـاركة

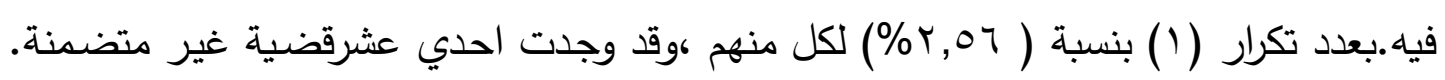
وجميعها قضايا مهمة وتضمينها يضيف للطالبات ويثقل تقديرهن لأهمية الملبس من الناحية الاجتماعية مع تحقيق متطلبات التمية المستدامة في الملابس.

سادسا: قضايا البعد البيئي لرؤية مصر • "ر •م في مجال الملابسر والنسيج. تــم تحليـل محتــوي كتــاب الاقتصــاد المنزلــي لطالبـات الصــف الأول الثــانوي الأزهــري (مجـال الملابس والنسـيج) للتعـرف علـي مـدي تتاولـه لقضــايا البعـد البيئسي فـي

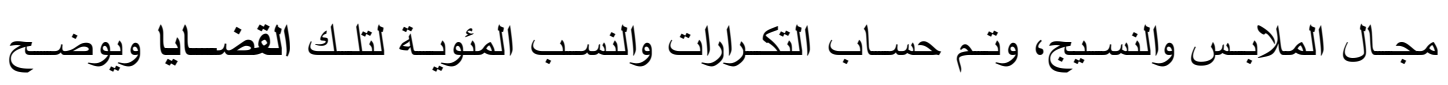
الجدول (^) ذلك. 
جلول ( ) التكرارات والنسب المئوية لقضايا البعد البيئي لرؤية مصر • •r المتضمنة بمحتوي كتاب الاقتصاد

المنزلي لطالبات الصف الأول الثانوي الأزهري في مجال الملابس والنسيج مفروليج

\begin{tabular}{|c|c|c|c|c|c|c|}
\hline المئوية & التحضايا & الترتيب & المئوية & 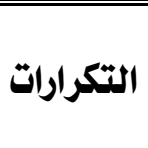 & 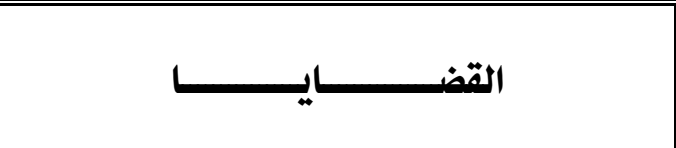 & هـ \\
\hline \multirow{19}{*}{$\%$} & \multirow{18}{*}{9} & 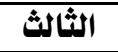 & 1,79 & $r$ & الوعى بأهمية البيئة والمحافظة عليها. & 1 \\
\hline & & الثالث & $\Lambda, 79$ & $r$ & الوعي بأشكال التلوث المختلفة & $r$ \\
\hline & & - & - & - & ترشيل استهلاك المياه العذبة. & $r$ \\
\hline & & - & - & - & ترشيد استهلاك الموارد غير المتجددة. & $\xi$ \\
\hline & & - & - & - & التوجه نحو الطاقة النظيفة صليقة البيئة. & 0 \\
\hline & & - & - & - & زيادة مساحة الرقعة الخضراء. & 7 \\
\hline & & 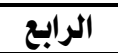 & $\xi, \Psi \xi$ & 1 & استخلام المصابيح الموفرة للطاقة. & 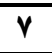 \\
\hline & & الرابع & $\xi, \psi \xi$ & $T$ & اعادة تدوير المخلفات. & $\Lambda$ \\
\hline & & الثالث & $\Lambda, 79$ & $r$ & علدم الاسراف فى الموارد بصفة عامة. & 9 \\
\hline & & - & - & - & دور القوانيز والتشريعات فى حماية البيئة. & 1. \\
\hline & & - & - & - & الأنشطة المدرسية ودورها فى نظافة وحماية البيئة. & 11 \\
\hline & & - & - & - & تنقية مياه الشرب والحفاظعليها. & ir \\
\hline & & - & - & - & 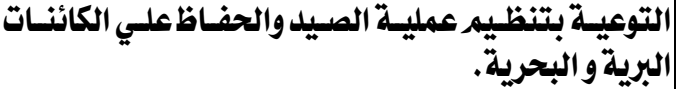 & ir \\
\hline & & - & - & - & محاربة التصحر والجفاف وإزالة الغابات. & $1 \varepsilon$ \\
\hline & & الثاني & IV,rq & $\xi$ & تنمية الثروة الحيوانية والنباتية. & 10 \\
\hline & & - & - & - & توفير الخدمات اللائقة وتعميم الكهرباء. & 17 \\
\hline & & الأول & $r, Y \cdot$ & 0 & الأمن في مجال العمل. & iv \\
\hline & & الأول & $r I, r r$ & 0 & تنمية القيم الجمالية. & 11 \\
\hline & & & 1... & rr & المجموع - المجوع & \\
\hline
\end{tabular}

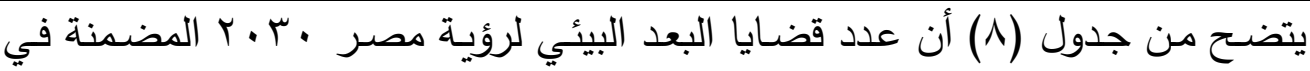

محتوي كتاب الاقتصـاد المنزلي المقرر علي طالبات الصف الأول الثانوي الأزهري في مجال

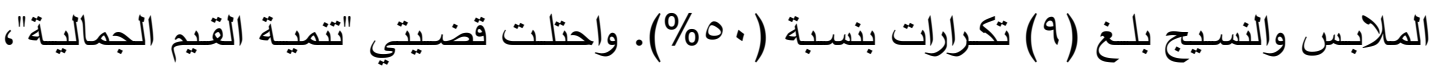

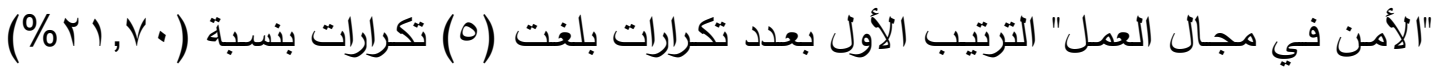

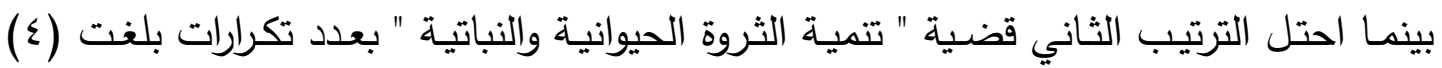

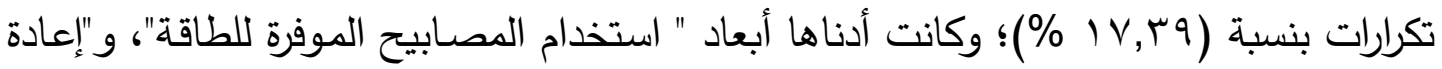

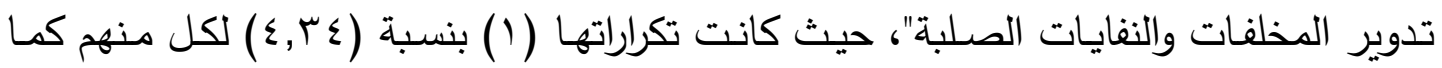

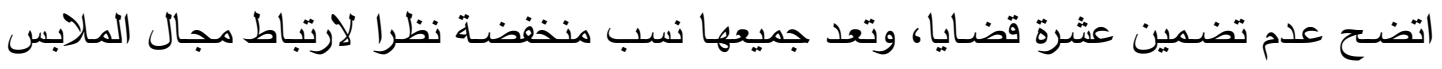

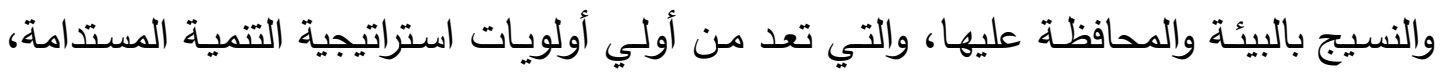

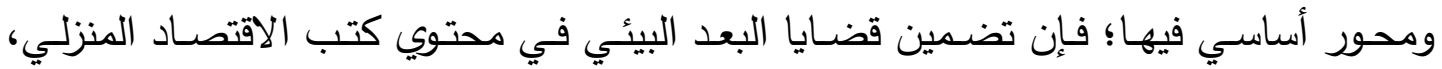
والتأكيد علي القضايا ذات العلاقة بحسن استخدام الموارد وتدوير المخلفات الملبسية والمحافظة

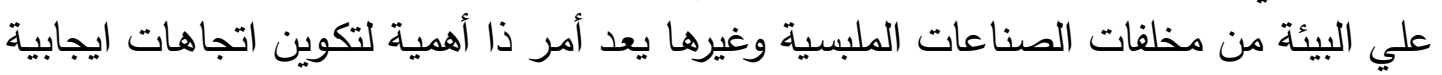


لاي الطالبات نحو تحقيق متطلبات الاستدامة مدي الحياة وعلي ذلك فلابد من تضمين قضـايا

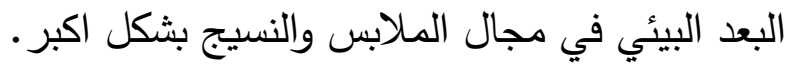

وبذلك تمت الاجابة عن السؤال المتفرع الذي نص علي "ما مدي تضيكي تضمين محتوي كتاب

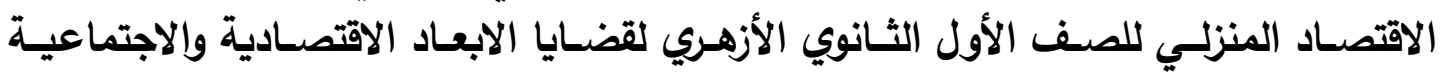
والبيئية لرؤية مصر · ب • ب (في مجال الملابس والنسيج).

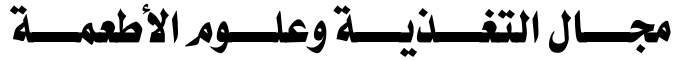

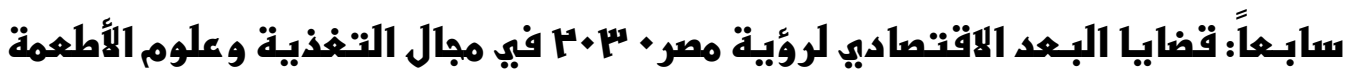
تم تحليل محتوي كتاب الاقتصاد المنزلي للصف الأول الثانوي الأزهري (مجال التغذية ولمدية

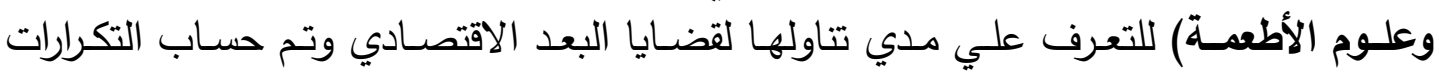

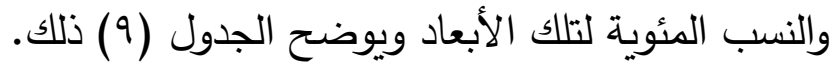

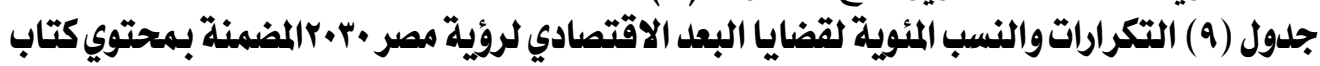

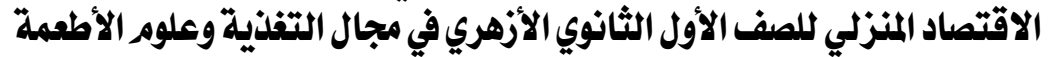

\begin{tabular}{|c|c|c|c|c|c|c|}
\hline المئوبة & التقخشقيا & الترتيب & المئوية & 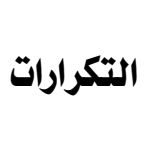 & 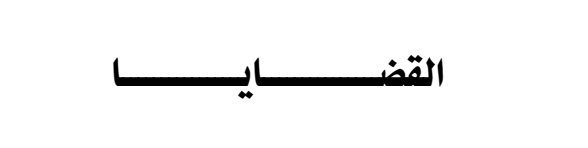 & 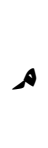 \\
\hline \multirow{22}{*}{$\% r \wedge, \cdot 9$} & \multirow{22}{*}{$\wedge$} & الرابع & 0,00 & 1 & التوسع في (الصناعة والتجارةوالزراعة) المستدامة & 1 \\
\hline & & 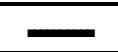 & - & - & المحافظة علي المناطق السياحية & $r$ \\
\hline & & $\overline{-}$ & $\overline{-}$ & $\overline{-}$ & تشجيع السياحة الداخلية & $\bar{r}$ \\
\hline & & $\overline{-}$ & $\overline{-}$ & - & احترامروتقدير العمل اليدوي & $\xi$ \\
\hline & & $=$ & $=$ & - & تفضيل المنتج المحلي عن المستورد & 0 \\
\hline & & $\overline{-}$ & $\overline{-}$ & $=$ & الحد من التفاوت في الدخل & 7 \\
\hline & & - & - & - & تحقيق الأمن الفذائي & $\mathrm{v}$ \\
\hline & & $=$ & $=$ & 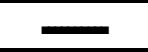 & الاكتفاء الذاتي وخاصة الأسر الريفية & $\Lambda$ \\
\hline & & الأول & rr, rr & 9 & ترشيل أنماط الانتاجوالاستهلاك & 9 \\
\hline & & - & $=$ & $=$ & تحسين نوعية المرافق العامة & 1. \\
\hline & & الثالث & 11,11 & $r$ & التصرف في حلود الامكانات المتاحة & 11 \\
\hline & & - & $\overline{-}$ & - & المشاركة في القرارات الأسرية الهامة وفي الميزانية & ir \\
\hline & & الرابع & 0,00 & 1 & ايجاد فرص جديلدة لحل مشكلة البطالة & IT \\
\hline & & الرابع & 0,00 & 1 & ادخال التكنولوجيا في جميع المجالات & is \\
\hline & & - & - & ـ & تشجيع المشروعات الصفيرة & 10 \\
\hline & & $\overline{-}$ & - & - & الثروات الطبيعية وطرق المحافظة & 17 \\
\hline & & الثاني & $r Y, Y Y$ & 0 & حسن استخدام الموارد المتاحه & IV \\
\hline & & 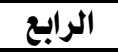 & 0,00 & 1 & تطبيق الاسلوب العلمي في الأدراة & 11 \\
\hline & & 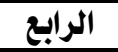 & 0,00 & 1 & العلاقة بين اقتصاديات الأسرةوتتدم المجتمع & 19 \\
\hline & & - & - & - & تحقيق مبلأ الشفافية والمساءلة & $r \cdot$ \\
\hline & & - & - & - & التجلديلوالابتكار & rI \\
\hline & & & 1... & 11 & 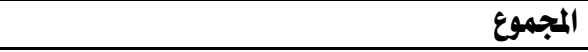 & \\
\hline
\end{tabular}


يتضـح من جدول (9) أن قضايا البعد الاقتصادي لرؤية مصر •r.r المضمنة في محتوي كتاب الاقتصـاد المنزلي المقررعلي طالبات الصف الأول الثانوي الأزهري في مجال التغذية وعلوم الأطعمة بلغ (^) قضايا بنسبة (9 . . ب \% \%)

واحتلت قضـية "ترشيد أنمـاط الانتـاج والاسـتهلاك" الترتيب الأول بعدد تكـرارات (ج)

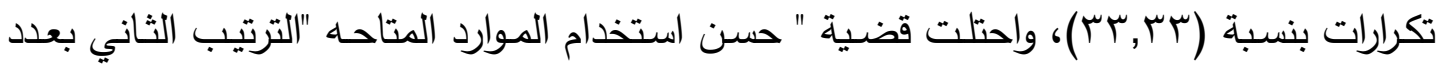

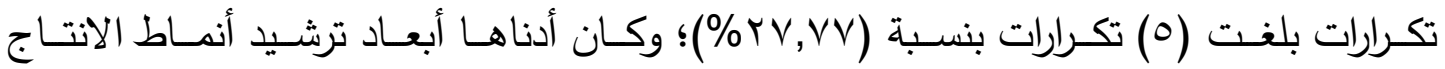
والاستهلاك"، "ايجاد فرص جديدة لحل مشكلة البطالة "، ادخال التكنولوجيا في جميع المجالات"، "تطبيق الاسلوب العلمي في الأدراة "، "العلاقـة بين اقتصـاديات الأسـرة وتقدم المجتهـع "بعدد تكرارات ( ) وبنسبة (0,00) وقد وجدت ثـلاث عشرة قضية غير مضمنة. وتعد هذه النسب ضعيفة جدا سواء النسبة الكلية، أو نسب تضمين القضايا، فضلا عن القضـايا غير المضمنة في ضوء أهمية مجال التغذية وعلوم الأطعمة في دعم متطابات البعد الاقتصادي، ويرجع ذلك إلي إرتباط الغذاء واستهلاكة وانتاجه بالبعد الاقتصـادي فالغذاء من أكثر المستهلكات ذات العلاقة باستراتيجية التتمية المستدامة وأهدافها التي من أهمها القضاء علي الجوع، وعلاقة الغذاء بالصحة

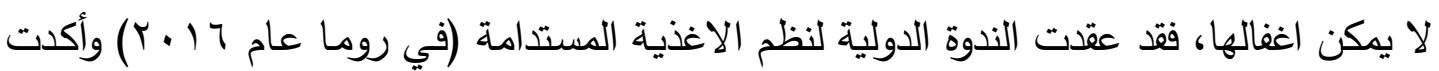
علي العلاقة بين التغذية والتتمية الاقتصادية والاجتماعية للدول، وأن الاشخاص الذين يحصلون علي التغذية الجيدة هم الذين يدفعون اجندات التتمية الاقتصادية. وعلي ذلك لابد من تضمين قضايا البعد الاقتصادي لرؤية مصر • • ب في محتوي التغذية وعلوم الأطعمة بكتاب الاقتصاد المنزلي للصف الأول الثانوي الأزهري.

\section{ثامناً : قضايا البعد الاجتما عي لرؤية مصر •"م ·م في مجال التغذية و علوم الأطمعة :}

تــم تحليـل محتــوي كتــاب الاقتصـــاد المنزلـــي للصــف الأول الثـانوي الأزهـري

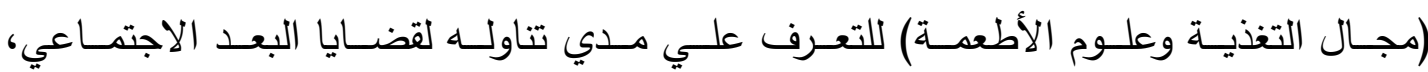
وتم حساب التكرارات والنسب المئوية لتلك القضايا ويوضح الجدول (• ( ) ذلك. 
جدول (•1) التكرارات والنسب المئوية لقضايا البعد الاجتماعي لرؤية مصر •r+r المضمنة بمحتوي كتاب

الاقتصاد المنزلي لطالبات الصف الأول الثانوي الأزهري في مجال التفذية وعلوه الأطعمة

\begin{tabular}{|c|c|c|c|c|c|c|}
\hline المئوية & |المتحقايا & الترتيب & المئوية & | التكرارات & 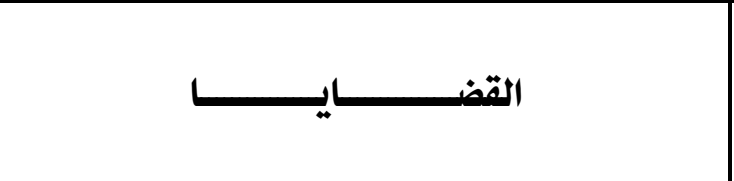 & \\
\hline \multirow{21}{*}{$r, \eta$} & \multirow{20}{*}{1.} & | - اخامس & $\xi, 70$ & $r$ & | احتزام حقوق الانسان. & \\
\hline & & الخامس & $\{, 70$ & r & | احترام الأنظمة والتشريعات والقوانين. & r \\
\hline & & - & - & - & |تحسين نوعية الحياة فى المناطق الفقيرة. & $r$ \\
\hline & & - & $=$ & $\longrightarrow$ & |المشاركة الفاعلة فى الحياة السياسية. & \\
\hline & & - & - & - & |تعزيز حب الوطن والانتماء له. & 0 \\
\hline & & 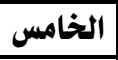 & $\xi, 70$ & $r$ & تحقيق الساواةوالعدالة في توزيع الموارد بين الأجيال. & 7 \\
\hline & & 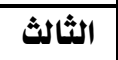 & $9, r \cdot$ & $\xi$ & دعم دور المرأة فى جميع المجالات. & 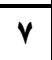 \\
\hline & & - & $\longrightarrow$ & - & | المحافظة علحي الممتلكات العامة والخاصة. & $\Lambda$ \\
\hline & & 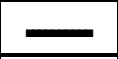 & $\longrightarrow$ & - & تقتدير العمل التطوعي والشاركة فيه. & 9 \\
\hline & & - & $=$ & - & |التصدي للشائعات الموجهة ضد الوطن ومؤسساته . & $1 \cdot$ \\
\hline & & $=$ & - & - & تدريب الطالبات علي التفكير السليه & 11 \\
\hline & & الثاني & $11,7 r$ & 0 & |النظافة ودورها في المحافظة علكي الصحة. & ir \\
\hline & & الأول & $\mathrm{HE}, \wedge \Lambda$ & 10 & الأغذية الفاسلة وأثرها علي صحة الانسان. & ir \\
\hline & & - & - & - & استخدام التقنيات الحديثة في حفظ وتخزين المنتجات الغذائية. & $1 \varepsilon$ \\
\hline & & 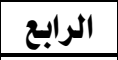 & $7,9 \mathrm{~V}$ & $r$ & تتعزيز القيه الأخلاقية التي تهذب الطالبة وتقوه المجتمع. & 10 \\
\hline & & - & $\longrightarrow$ & $\longrightarrow$ & الرعاية الصحية والتطعيم ضل الأمراض. & 17 \\
\hline & & 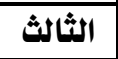 & $9, \%$. & $\xi$ & |الحرص على طلب العلم والتعله الذاتي المستمر. & iv \\
\hline & & - & - & 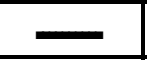 & |التوعية بأهمية تنظيم الأسرة. & 11 \\
\hline & & $=$ & 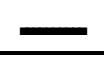 & - & اتجنب العنف والعمل علي تقبل الآخر & 19 \\
\hline & & 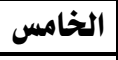 & $\xi, 70$ & $r$ & |تقدير الحياة الأسرية. & r. \\
\hline & & 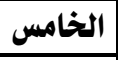 & $\xi, 70$ & $r$ & الحفاظعلي الهوية والعاداتوالتقاليد & ri \\
\hline & & & 1.. & $\xi r$ & المجموع & \\
\hline
\end{tabular}

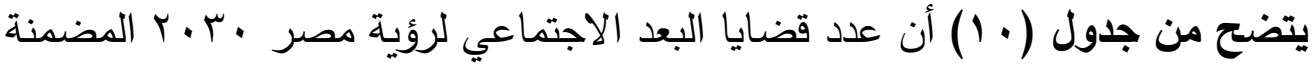

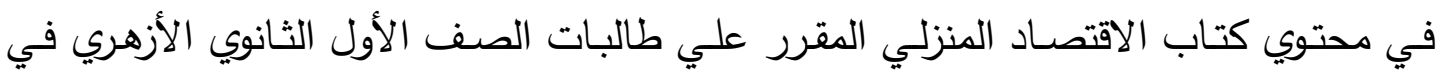

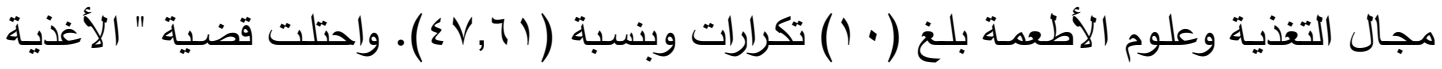
الفاسدة وأثرها علي صحة الانسان.."، الترتيب الأول بعدد تكرارات بلغت (0 (10)تكرار بنسبة

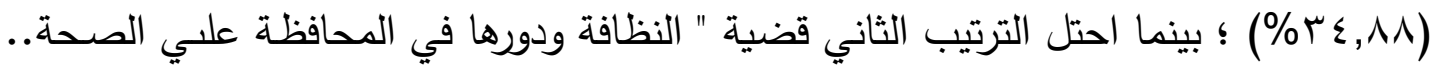
" بعدد تكرارات بلغت (0) تكرارات بنسبة (Y7, I ( \% ) )؛ وكانت أدناهـا أبعـاد " احترام حقوق الانسان " واحترام الأنظمة والتشريعات والقوانين ،وتحقيق المساواة والعدالة في توزيع الموارد بين 
الأجيال، وتقدير الحياة الأسرية، والحفاظ علي الهويـة والعادات والتقاليد. بعدد تكرار (ب) بنسبة

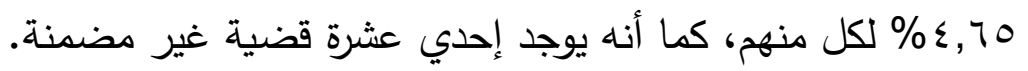
ويلاحظ ضعف نسب تضمين قضايا البعد الاجتماعي في مجال الغذاء والتغذية بكتاب

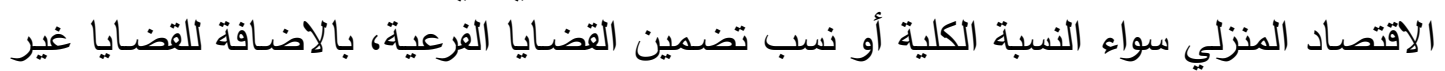

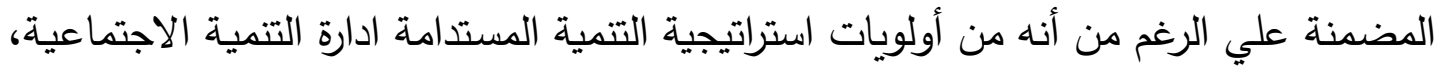

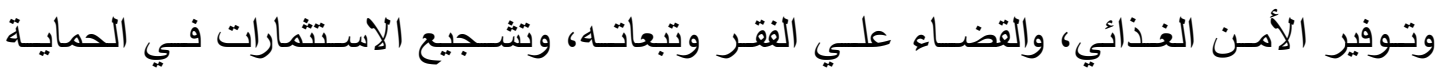

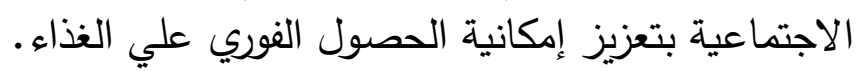

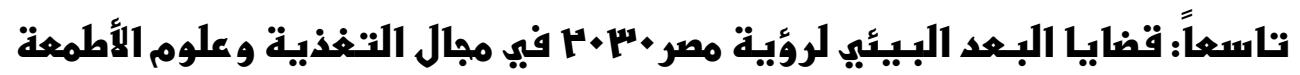

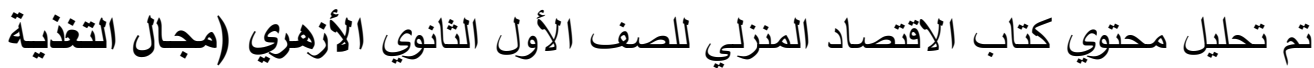

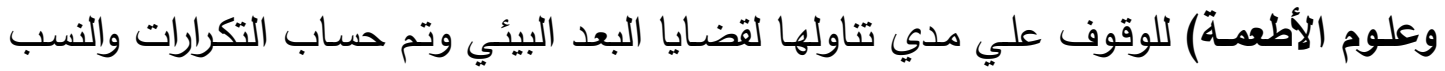

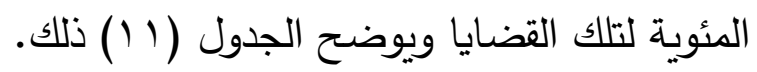

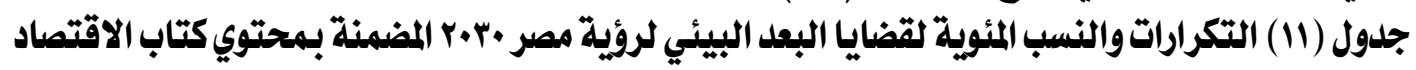

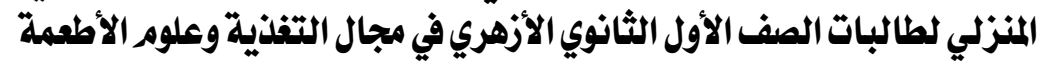

\begin{tabular}{|c|c|c|c|c|c|c|}
\hline المئوية & المتضمنة & الترتيب| & المئوية & 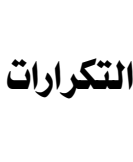 & القض & هـ \\
\hline \multirow{19}{*}{ \% } & \multirow{18}{*}{1} & - & - & - & الوعى بأهمية البيئة والمحافظة عليها. & 1 \\
\hline & & الأول & $r r, \wedge l$ & 0 & الوعي بأشكال التلوث المختلفة & r \\
\hline & & - & 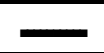 & - & ترشيل استهلاك الياه العذبة. & $r$ \\
\hline & & - & - & - & ترشيل استهلاك الموارد غير المتجلدة. & $\xi$ \\
\hline & & - & - & $\bar{\sigma}$ & التوجه نحو الطاقة النظيفة صليقة البيئة. & 0 \\
\hline & & - & 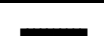 & - & زيادة مساحة الرقعة الخضراء. & 7 \\
\hline & & - & - & - & |استخلام المصابيح الموفرة للطاقة. & $v$ \\
\hline & & - & - & $\bar{Z}$ & اعادة تدوير المخلفات والنفايات الصلبة. & $\Lambda$ \\
\hline & & الأول & $r T, A l$ & 0 & علدم الاسراف فى الموارد بصفة عامة. & 9 \\
\hline & & 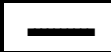 & - & - & دور القوانيز والتشريعات فى حماية البيئة. & 1. \\
\hline & & - & 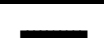 & 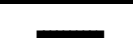 & |الأنشطة المدرسية ودورها فى نظافة وحماية البيئة. & 11 \\
\hline & & الرابع & $9,0 \mathrm{r}$ & r & تنقية مياه الشربوالحفاظعليها. & Tr \\
\hline & & - & - & - & التوعية بتنظيه عملية الصيدوالحفاظعلي الكائنات البريةوالبحرية. & Tr \\
\hline & & $\bar{\square}$ & - & - & محاربة التصحر والجفاف وازالة الغابات. & $1 \xi$ \\
\hline & & 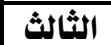 & $1 \xi, \uparrow \Lambda$ & $r$ & تنمية الثروة الحيوانيةوالنباتية. & 10 \\
\hline & & - & - & - & توفير الخدمات الللائقة وتعميهر الكهرباء. & 17 \\
\hline & & الرابع - ابع & $9,0 \mathrm{r}$ & r & | الأمن في مجال العمل & iv \\
\hline & & 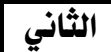 & $19, \cdot \xi$ & $\varepsilon$ & تنمية القيم الجمالية & 11 \\
\hline & & & $1 \cdots$ & m & 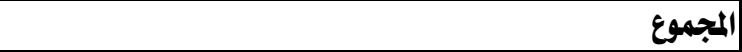 & \\
\hline
\end{tabular}




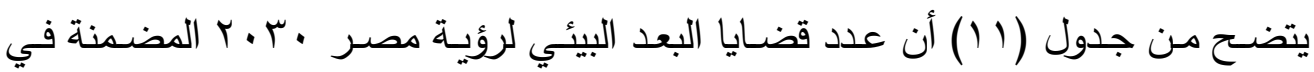

كتاب الاقتصاد المنزلي للصف الأول الثانوي الأزهري في مجال التغذيـة وعلوم الأطعمة بلغ (T) تكرارات وبنسبة (سr,سr\%). واحتلت قضيتي" الوعي بأشكال التلوث المختلفة "، " وعدم الاسراف

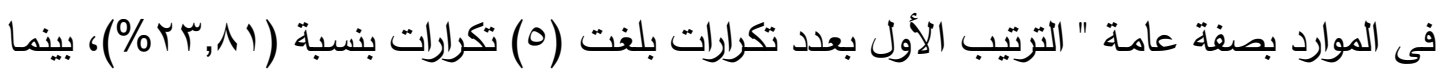

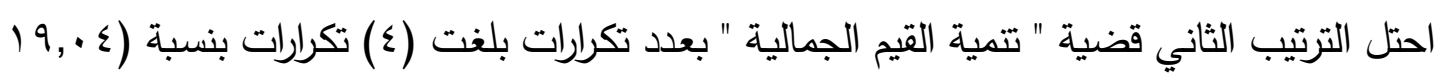

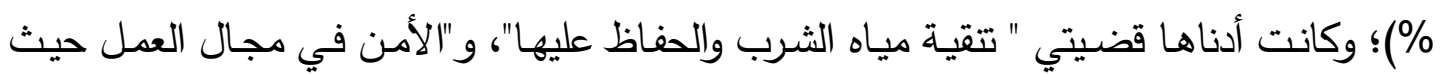
كانت تكراراتها (Y) بنسبة (9,0Y) لكل منهما. كما أنه يوجد اثنا عشر قضية غير مضمنه.

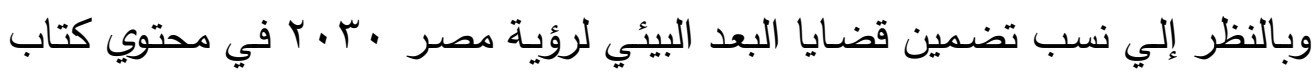

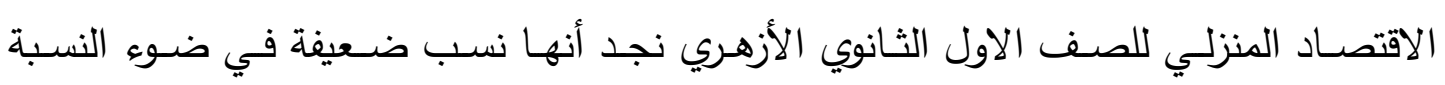
المحكيـة للبحث الحـالي، وفي ضـوء العلاقـة الوطيدة بين مجال الغذاء والتغذيـة والبعد البيئى البى

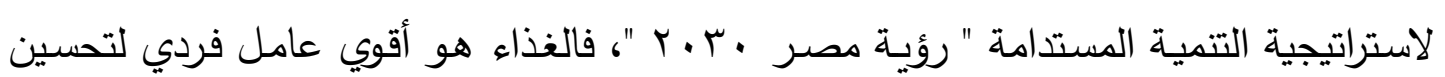

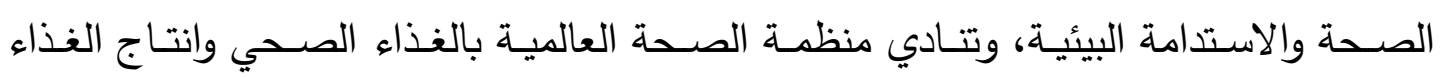
المستدام، واستهلاك الأغذية ذات الجودة المرتفعة ومنع الخمور والمخدرات والتدخين، فالانتاج ولاج غير الصحي للغذاء يهدد الاستقرار المناخي، ويهدد بالتدهور البيئي، فبدون تغيير تلك الأنظمة

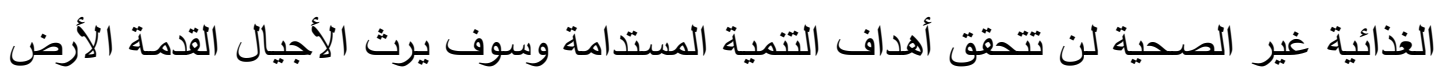
متدهورة وسكانها يعانون من الأمراض كسوء التغذية وغيرها، ومن هنا تظهر الحاجة لتضمين قضـايا البعـد البيئي في كتـاب الاقتصـاد المنزلـي مجـال الغـاءه والتغذيـة لاكسـاب مفاهيمهـا للطالبات والحرص علي تطبيقها فعليا. وبـذلك تمـت الاجابـة عن السؤال الذي نص علي "مـا مـدي تضـمين محتـوي كتـاب الاقتصـاد المنزلـي للصـف الأول الثـانوي الأزهـري لقضـايا الابعـاد الاقتصـادية والاجتماعيـة والبيئية لرؤية مصر • r • r في مجال (التغذية وعلوم الأطعمة).

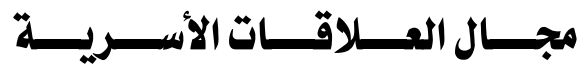

\section{عاشرا: قضايا البعد الاقتصادي لرؤية مصر • "بم •م في مجال العلاقات الأسربة}

تم تحليل محتوي كتاب الاقتصاد المنزلي لطالبات الصف الأول الثانوي الأزهري (مجال العلاقـات الاسـرية) للتعرف علي مدي تناولـه لقضـايا البعد الاقتصـادي وتم حسـاب التكرارات والنسب المئوية لتلك القضايا ويوضح الجدول (r ( ) ذلك. 


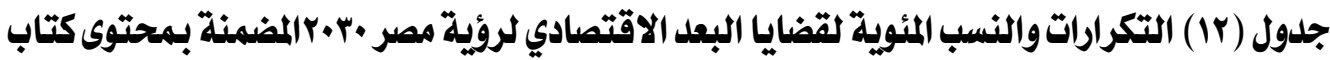

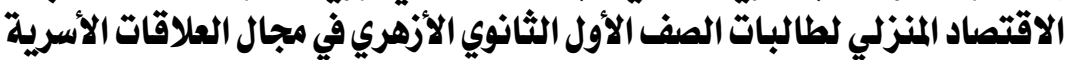

\begin{tabular}{|c|c|c|c|c|c|c|}
\hline المئوية & الملتحقيا & الترتيب & المئوية & 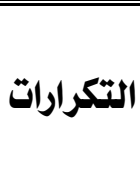 & الأبعــــــــــــــــاد & هـ \\
\hline \multirow{22}{*}{$\% \& r, \wedge 0$} & \multirow{22}{*}{9} & - & - & 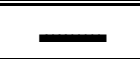 & التوسع في (الصناعة والتجارةوالزراعة) المستدامة & 1 \\
\hline & & - & $=$ & $=$ & المحافظة علي المناطق السياحية & $r$ \\
\hline & & $\bar{Z}$ & - & - & تشجيع السياحة الداخلية & $r$ \\
\hline & & 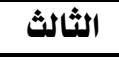 & $\Lambda, r r$ & 1 & احتراموتقدير العمل اليدوي & $\xi$ \\
\hline & & - & - & 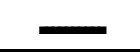 & تفضيل المنتج المحلي عن المستورد & 0 \\
\hline & & - & - & - & الحد من التفاوت في الدخل & 7 \\
\hline & & - & - & - & تحقيق الأمن الفذائي & $r$ \\
\hline & & & - & - & الاكتفاء الذاتي وخاصة الأسر الريفية & $\Lambda$ \\
\hline & & - & - & - & ترشيد أنماط الانتاجوالاستهلاك & 9 \\
\hline & & الثالث & $\Lambda, r \mu$ & 1 & |تحسين نوعية المراقق العامة & 1. \\
\hline & & الثالث & $\Lambda, r r$ & 1 & التصرف في حدود الامكانات المتاحة & 11 \\
\hline & & الثاني & 17,79 & r & |الشاركة في القرارات الأسرية الهامة وفي الميزانية & ir \\
\hline & & 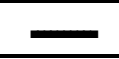 & $\longrightarrow$ & - & |ايجاد فرص جديدة لحل مشكلة البطالة & ir \\
\hline & & - & - & - & |ادخال التكنولوجيا في جميع المجالات & $1 \varepsilon$ \\
\hline & & الثالث & A,rr & 1 & |تشجيع الشروعات الصفيرة & 10 \\
\hline & & - & - & - & |الثروات الطبيعية وطرق المحافظة & 17 \\
\hline & & الثالث & $\Lambda, r \mu$ & 1 & |حسن استخلام الموارد المتاحه & iv \\
\hline & & {[} & - & $\longrightarrow$ & |تطبيق الاسلوب العلمي في الأدراة & in \\
\hline & & الثالث & $\Lambda, r \mu$ & 1 & | العلاقة بين اقتصاديات الأسرة وتقده المجتمع & 19 \\
\hline & & 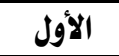 & ro & $r$ & |تحقيق مبلأ الشفافية والمساءلة & r. \\
\hline & & 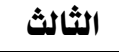 & $\Lambda, r \mu$ & 1 & | التجديل والابتكار & $r$ \\
\hline & & & 1.. & ir & 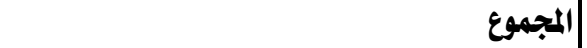 & \\
\hline
\end{tabular}

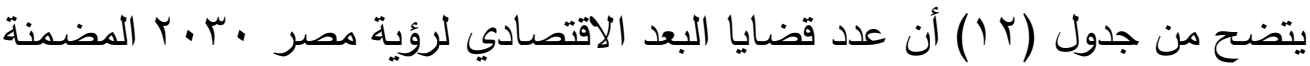
في محتوي كتاب الاقتصاد المنزلي للصف الأول الثانوي الأزهري في مجال العلاقات الأسرية

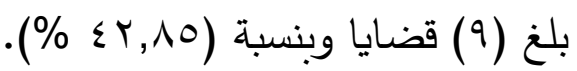

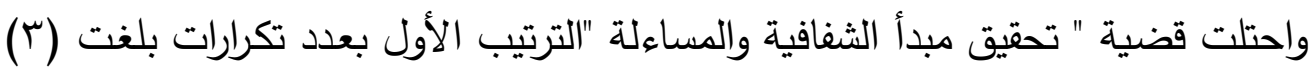
تكرارات بنسبة (0Y\%)؛ وكـان أدناهـا أبعـاد " احترام وتقدير العمـل اليدوي، وتحسـين نوعيـة المرافق العامة، والتصرف في حدود الامكانات المتاحة، وتثجيع المشروعات الصغيرة، وحسن

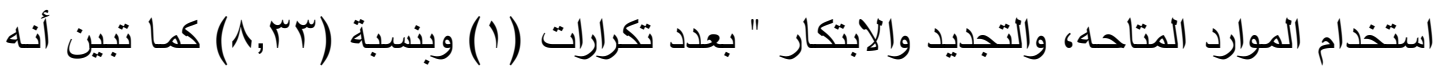
يوجد عدد اثنا عشرة قضية غير مضمنة. 
وهذهـ النسـب أقـل مـن النسـبة المحكيـة للبحـث الحـالي، وإن تضـــين قضـايا البعـــ

الاقتصادي لرؤية مصر • • r في مجال العلاقات الاسرية يعد مهم، حيث إن مجال العلاقات الأسرية يهتم بدراسة الأسرة واحتياجاتها والعلاقات بين أفرادها وكل ما يتعلق باقتصاديات الاتهردات الأسرة

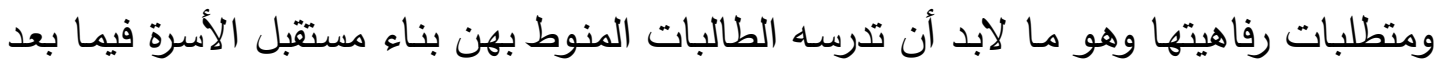

وعل ذلك فإن تضمين قضايا البعد الاقتصادي ممكن ومتاح لارتباطة بالمجال بشكل واضح.

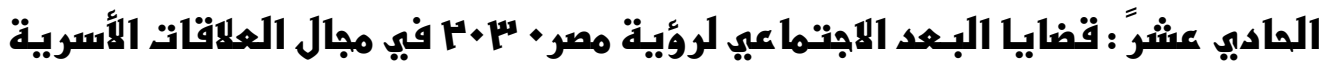
تم تحليـل محتـوي كتـاب الاقتصـاد المنزلـي للصـف الأول الثانوي الأزهـري (مجـال

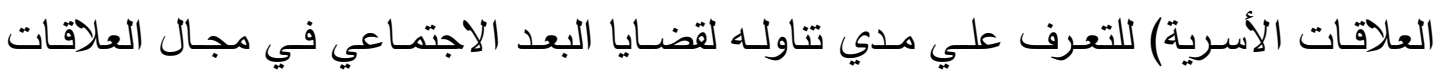
الأسرية؛ وتم حساب التكرارات والنسب المئوية لتلك القضايا ويوضح الجدول (ب ا ) ذلك.

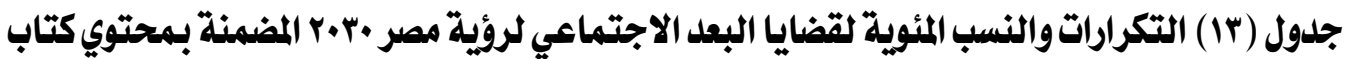
الاقتصاد المنزلي لطالبات الصف الأول الثانوي الأزهري في مجال العلاقات الأسرية لرويه مصنية

\begin{tabular}{|c|c|c|c|c|c|c|}
\hline المئوية & المتحقة التضاي & الترتيب & المئويةّ & 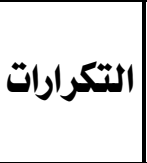 & 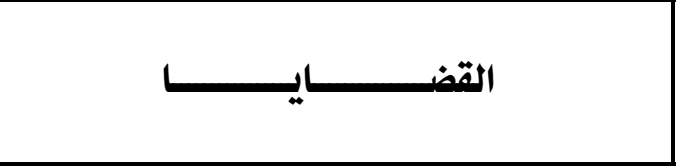 & هـ \\
\hline \multirow{21}{*}{$\% 97,79$} & \multirow{21}{*}{ 1\& } & الثاني & $1 \%, \cdot \xi$ & 7 & احتزاه حقوق الانسان. & 1 \\
\hline & & 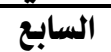 & r,IV & 1 & احتراه الأنظمة والتشريعاتوالقوانين. & $r$ \\
\hline & & 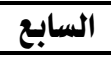 & $r, I V$ & 1 & تحسين نوعية الحياة فى المناطق الفقيرة. & $r$ \\
\hline & & 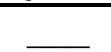 & - & - & المشاركة الفاعلة فى الحياة السياسية. & $\xi$ \\
\hline & & - & - & - & تعزيز حب الوطن والانتماء له. & 0 \\
\hline & & السادس & $\xi, r \xi$ & $r$ & تحقيق المساواة والعدالة في توزيع الموارد بين الأجيال. & 7 \\
\hline & & الخامس & 7,Or & $r$ & دعم دور المرأة فى جميع المجالات. & $\checkmark$ \\
\hline & & 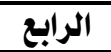 & $\Lambda, 79$ & $\varepsilon$ & المحافظة علىي الممتلكات العامة والخاصة. & $\Lambda$ \\
\hline & & 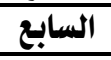 & $r, I Y$ & 1 & تتدلير العمل التطوعي والمشاركة فيه. & 9 \\
\hline & & - & $\overline{-}$ & 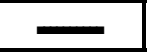 & التصدي للشائعات الموجهة ضد الوطن ومؤسساته. & 1. \\
\hline & & - & $=$ & $\overline{-}$ & تلدريب الطالبات علي التفكير السليير & 11 \\
\hline & & السادس & $\xi, \psi \xi$ & $r$ & النظافة ودورها في المحافظة على الصحة. & Ir \\
\hline & & - & - & $\overline{-}$ & الأغذية الفاسلة وأثرها علي صحة الانسان. & Ir \\
\hline & & - & $\overline{-}$ & $\overline{-}$ & استخلام التقنيات الحليثة في حفظوتخزين المنتجات الفذائية. & $1 \xi$ \\
\hline & & - & $\overline{-}$ & $\overline{-}$ & تعزيز القيه الأخلاقية التي تهذب الطالبة وتقوه المجتهم. & 10 \\
\hline & & الأول & $r,\{Y$ & $1 \cdot$ & الرعاية الصحية والتطعيم ضد الأمراض. & 17 \\
\hline & & 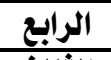 & $\Lambda, 79$ & $\varepsilon$ & الحرص على طلب العلم والتعلم الذاتي المستمر. & iv \\
\hline & & الثالث & $1 \cdot, 17$ & 0 & التوعية بأهمية تنظيه الأسرة. & 11 \\
\hline & & 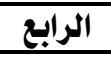 & 1,79 & $\xi$ & اتجنب العنف والعمل علي تقبل الآخر & 19 \\
\hline & & 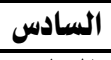 & $\xi, \Psi \varepsilon$ & $r$ & تقدير الحياة الأسرية. & r. \\
\hline & & 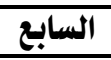 & $r, I V$ & 1 & الحفاظعلي الهوية والعاداتوالتقاليد & $r$ \\
\hline & & & $1 \cdots$ & $\$ 7$ & المجموع & \\
\hline
\end{tabular}




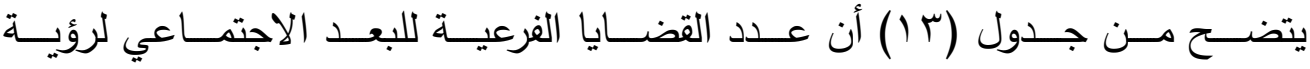

مصــر • • • r المضـــنة فـي محتـوي كتــاب الاقتصــاد المنزلــي للصـف الأول الثـانوي الأزهـري فـي مجـال العلاقـات الاسـرية بــن (ع () تكــرار وبنسـبة (7 7,7 7). واحتلــات قضــية " الرعايـة الصــية والتطعـيم ضـــ الأمـراض."، الترتيـب الأول بعـدد تكـرارات بلغـــ

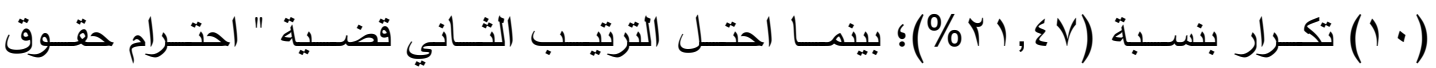

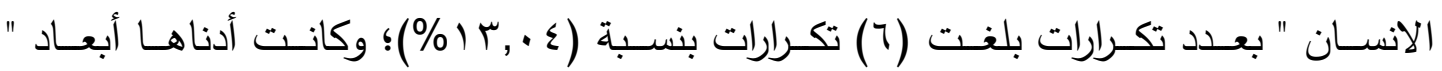
احتـرام الأنظـــة والتشـريعات والقــوانين ،"وتحسـين نوعيــة الحيــاة فــى المنــاطق الفقيـرة،

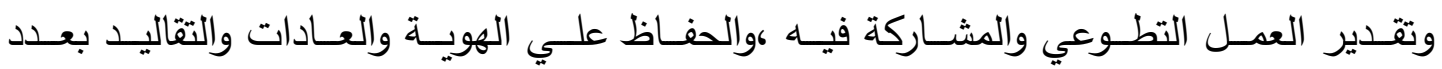
تكرارات ( () بنسبة V., V\% لكل منهم، كما أنه يوجد عدد (V) قضايا غير مضمنة. يتضــح مـن النســب المئويـة والتكــرارات أنهـــا أقـل مـنـ النسـبة المحكيــة للبحــث الحـالي ولكـن النسـبة الكليـة للبعـد الاجتمـاعي فـي مجـال العلاقـات الأسـرية تعـد أعلـي نسبة في جميـع الأبعـاد الاجتماعيـة للمجـالات الأربعـة للاقتصـاد المنزلـي وقـد يرجـع ذلكك لأن مجـال العلاقـات الأسـرية يغلـب عليـه الطـابع الاجتمـاعي، ولا يعنـي ذلـك بقـاء الوضـع علي مـا هو عليـه بـل بـالعكس فـإن هذا يعد ميزه لتدعيم المحتوي بمزيـــ من قضـايا البعد الاجتماعي، وتضمين باقي القضايا غير المضمنه في المحتوي.

الثاني عشر : قضايا البعد البيئي لرؤية مصر • "م +م في مجال العلاقات الأسرية. تـــ تحلــلـل محتـوي كتــاب الاقتصــاد المنزلــــ للصــف الأول الثـانوي الأزهــري (مجــال العلاقــات الأســرية) للتعـرف علـي مــدي تناولهـا لقضــايا البعـد البيأسي لحسـاب التكرارات والنسب المئوية لتلك القضايا ويوضح الجدول (ع () ذلك. 
جلول (عا) التكرارات والنسب المئوية لقضايا البعد البيئي لرؤية مصر •r.r المضمنة بمحتوي كتاب الاقتصاد المنزلي للصف الأول الثانوي الأزهري في مجال العلاقات الأسرية

\begin{tabular}{|c|c|c|c|c|c|c|}
\hline المئوية & المتضمنيا & الترتيب & المئوية & 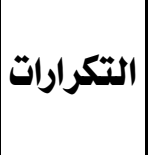 & 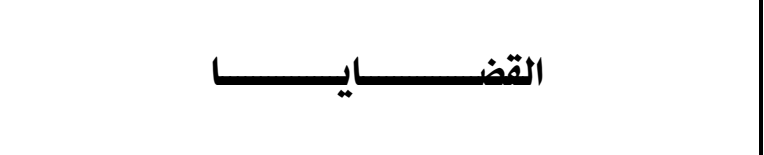 & \\
\hline \multirow{18}{*}{$\%$ \% } & \multirow{18}{*}{1} & الثاني & $1 \%, 0$ & 1 & | الوعى بأهمية البيئة والمحافظة عليها. & 1 \\
\hline & & الأول & ro & r & |الوعي بأشكال التلوث المختلفة & $r$ \\
\hline & & $=$ & - & - & ترشيد استهلاك الياه العذبة. & $r$ \\
\hline & & $\overline{-}$ & - & - & ا ترشيد استهلاك الموارد غير المتجددة. & $\xi$ \\
\hline & & $\overline{-}$ & $=$ & - & التوجه نحو الطاقة النظيفة صليقة البيئة. & 0 \\
\hline & & - & 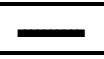 & - & زيادة مساحة الرقعة الخضراء. & 7 \\
\hline & & $\overline{-}$ & $\overline{-}$ & - & | استخدام المصابيح الموفرة للطاقة. & $\mathrm{v}$ \\
\hline & & $\overline{-}$ & - & $\overline{-}$ & اعادة تدوير المخلفات والنفايات الصلبة. & $\Lambda$ \\
\hline & & 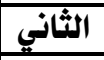 & Ir,o & 1 & علدم الاسراف فى الموارد بصفة عامة. & 9 \\
\hline & & - & - & $=$ & لدور القوانيزوالتشريعات في حماية البيئة. & $1 \cdot$ \\
\hline & & $\overline{-}$ & $\overline{-}$ & $\overline{-}$ & |الأنشطة المدرسية ودورها في نظافة"وحماية البيئةً. & 11 \\
\hline & & $\overline{-}$ & - & - & تنقية مياه الشرب والحفاظعليها. & Ir \\
\hline & & $=$ & $\bar{Z}$ & $=$ & التوعية بتنظيه عملية الصيد والحفاظعلي الكائنات البرية والبحرية. & 1 \\
\hline & & $\overline{-}$ & $\overline{-}$ & $\overline{-}$ & محاربة التصحر والجفاف وإزالة الغابات. & $1 \varepsilon$ \\
\hline & & - & - & - & تنمية الثروة الحيوانية والنباتية. & 10 \\
\hline & & 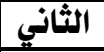 & $1 r, 0$ & 1 & توفير الخدمات اللائقة وتعميه الكهرباء. & 17 \\
\hline & & الأول & ro & $r$ & الأمن في مجال العمل & $\overline{|V|}$ \\
\hline & & الثاني & Ir,0 & 1 & اتنمية القيمر الجمالية & 11 \\
\hline & & & 1... & $\hat{\Lambda}$ & 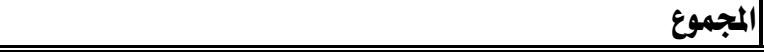 & \\
\hline
\end{tabular}

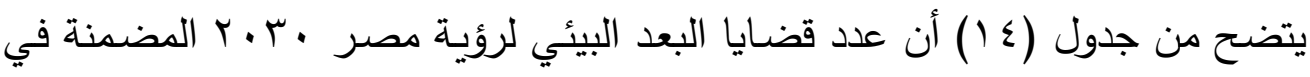

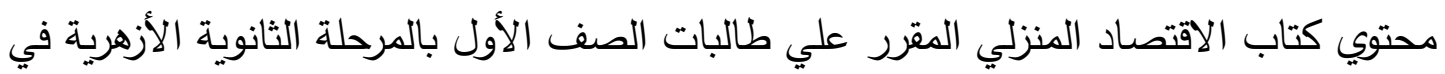
مجال العلاقات الأسرية بلغ (ך) تكرارات وبنسبة (سب,rr\%). واحتلت قضيتي" الوعي بأشكال التلوث المختلفـة "، " الأمـن في مجـال العدل " الترتيب الأول بعدد تكرارات بلغت (ب) تكرار

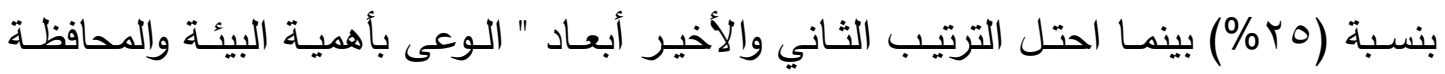

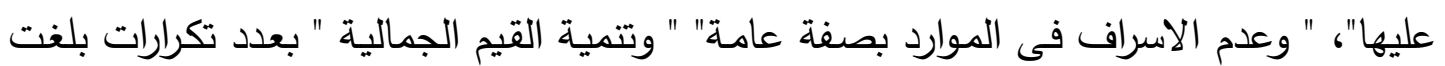

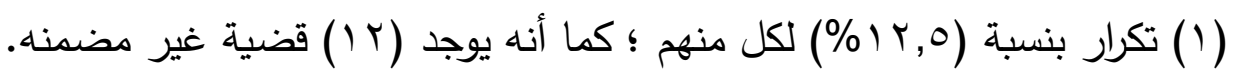
يتضح من خلال عرض النتائج أن نسب تضمين البعد البيئي بمجال العلاقات الأسرية يعد ضـعيف رغم ثراء ذلك المجال بما يتيح سهولة تضمين جميع القضـايا التي تخص حياة الأسرة وأمن مناخها وبيئتها بشكل عام، وعلي ذلك لابد من تضمين قضايا البعد البيئي بشكل أكبر لتحقيق متطلبات التتمية المستدامة. 
وبذلك تم الاجابة عن السؤال الذي نص علي "ما مدي تضمين محتوي كتاب الاقتصاد المنزلي للصف الأول الثانوي الأزهري لقضايا الابعاد الاقتصادية والاجتماعية والبيئية لرؤيسة

$$
\text { مصر · ب ·. في مجال (العلاقات الأسرية). }
$$

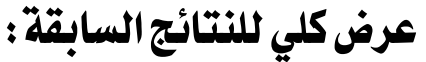

بمقارنة النسب المئوية للقضايا المتضمنة بمحتوي كتاب الاقتصاد المنزلي في كل مجال من مجالات الاقتصاد المنزلي ككل كما اتضح من الجداول من () إلي () ويوضحه بشكل كلي لئي

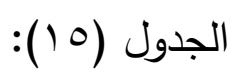

جلدول (10) النسب المئوية لقضايا رؤية مصر •r.r المتضمنة بمحتوي كتاب الاقتصاد المنزلي للصف الاول

\begin{tabular}{|c|c|c|c|c|}
\hline العلاقات الأسرية & التفلية وعلوم & الملابس والنسيج & الاسرة ادارة مؤسسات & \\
\hline$\% \leqslant r, \wedge 0$ & $\%{ }^{*} \wedge, \cdot q$ & $\%$ \%, rA & $\% 97,7$ & اقتصادي \\
\hline$\% 77,77$ & $\% \varepsilon v, \eta 1$ & $\% \leqslant v, \eta 1$ & $\% \Psi 1,\{v$ & اجتماعي \\
\hline$\% \pi r, r r$ & $\% \pi r, r r$ & $\%$ & $\%$ & بيئي \\
\hline
\end{tabular}

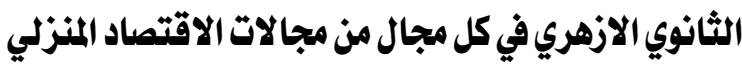

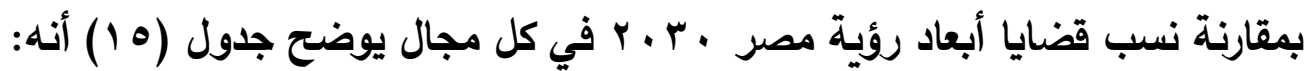

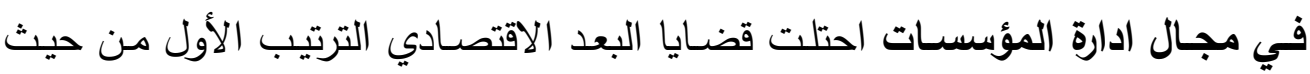

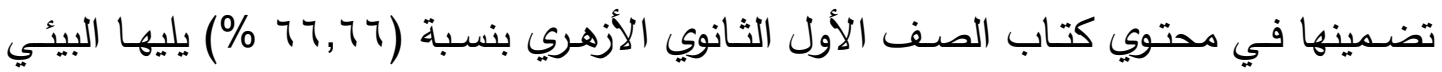

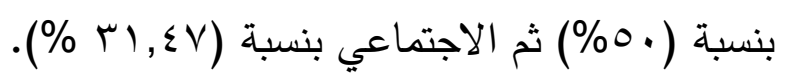

وفي مجال الملابس والنسيج يوضح الجدول أن قضاعبا البعد الاقتصادي احتلت الترتيب

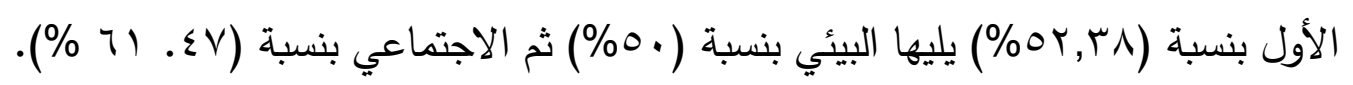

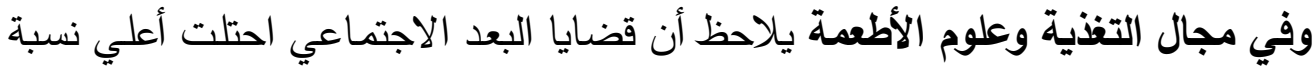

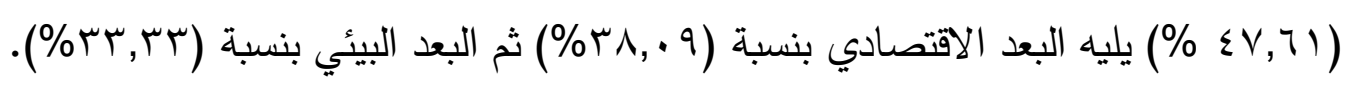

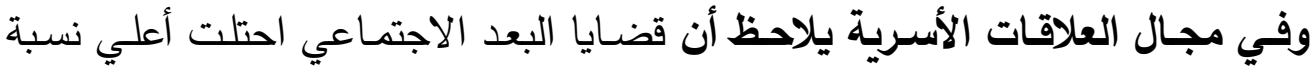

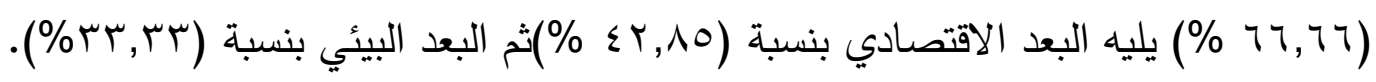

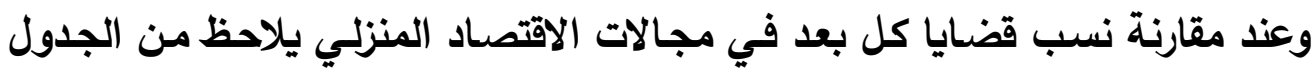

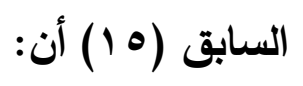


قضــايا البعـد الاقتصـادي: متضـنة في المحتوي بنسبة( 7,77 \%) في مجـال ادارة مؤسسات الأسرة والطفولة وهي أعلي نسبة يليها مجال الملابس والنسيج (^ז, ب \% \%)ثم مجال

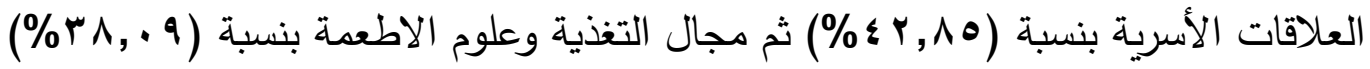
وبالنسبة لقضـايا البعد الاجتمـاعي: المضمنة في المحتوي فقد احتل مجال العلاقات الاسـرية الترتيب الأول بنسـبة (7 7,77\%) وحصـل مجـالي الملابس والنسـيج والتغذيـة علي

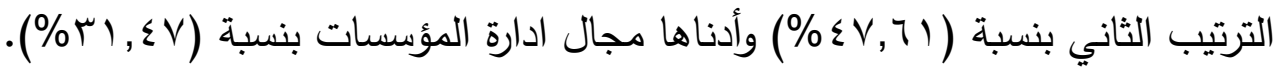
أما قضايا البعد البيئي: المضمنة في المحتوي فقد احتل مجالي ادارة مؤسسات الأسرة والطفولة، الملابس والنسيج الترتيب الأول بنسبة ( •0\%) بينما حصل مجالي التغذية والعلاقات الأسرية علي الترتيب الثاني بنسبة (سب,سب\%).

وتري الباحثة أن طبيعة المجال قد يكون سبب في تغليب وجود بعض القضايا عن بعضها الآخر أو ارتفاع مستوي تضمين البعد في المجال عن مستوي الآخر، ولكن بثكل عام فبإن النسـب جميعها أقل مـن المطلوب تحقيقـة، تنفيـا لمتطلبـات اسـتراتيجية التنميـة

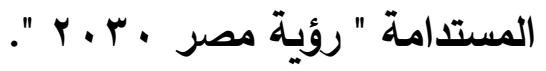
كمـا تم حسـاب مجمـوع التكرارات والنسـب المئويـة لجميع قضـايا أبعـاد رؤيسة مصر • . . . المضمنة بكتاب الصف الأول بالمرحلة الثانوية الأزهرية في مجالات الاقتصاد المنزلي الأربعة والجدول (7 ا ) يوضح ذلك

جدول (17) مجموع التكرارات والنسب المئوية لجميع قضايا أبعاد رؤية مصر •r.r المضمنة بمحتوي كتاب الصف الأول بالمرحلة الثانوية الأزهرية في مجالات الاقتصاد المنزلي ككل

\begin{tabular}{|c|c|c|}
\hline النسبة المئوية & عدد القضايا المتحققة & القضايا الكلية للأبعاد \\
\hline$\%$ & $\xi r$ & البعل الاقتصادي \\
\hline$\% 10$ & 00 & البعد الاجتماعي \\
\hline$\%$ \%1, 79 & r. & البعد البيئي \\
\hline$\%$ or,q & IrV & المجمبوع \\
\hline
\end{tabular}

يتضـح مـن الجدول (7 ( ) أن نسبة تضـين محتوي كتاب الاقتصـاد المنزلي للصف

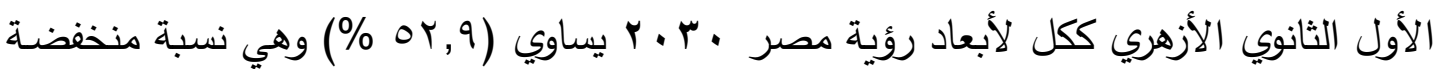

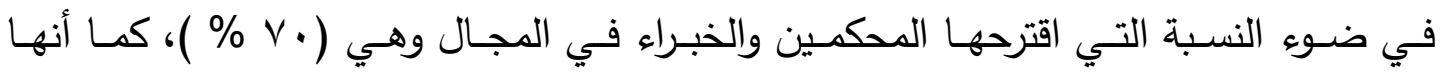




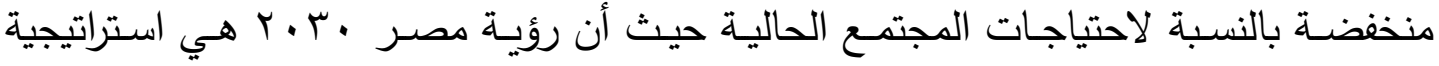

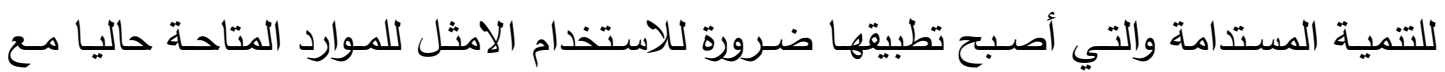

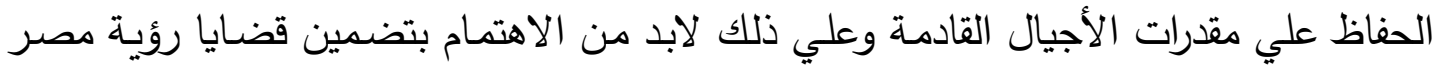

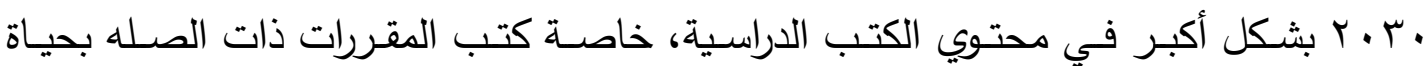

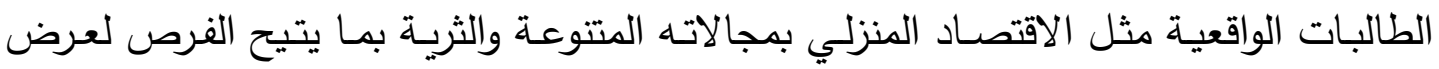
المزيد من القضايا بصورة مباشرة أو ضمنية، نظرية أو تطبيقية.

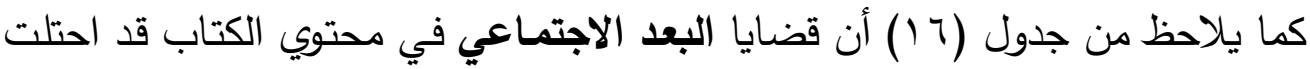

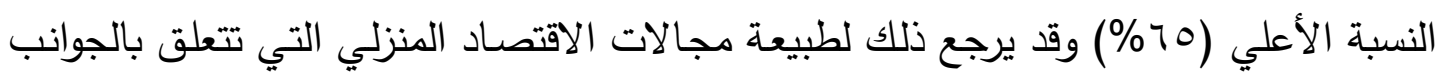

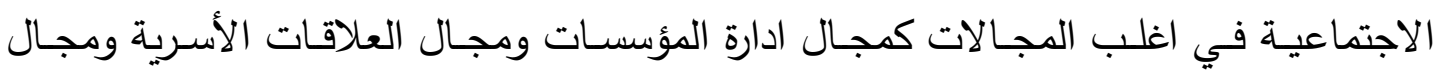

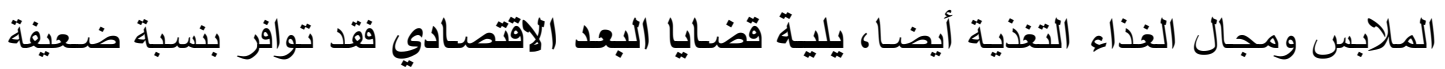

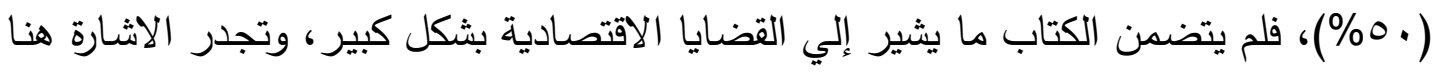

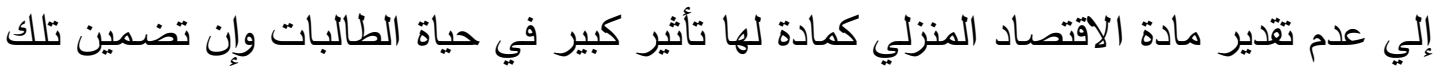

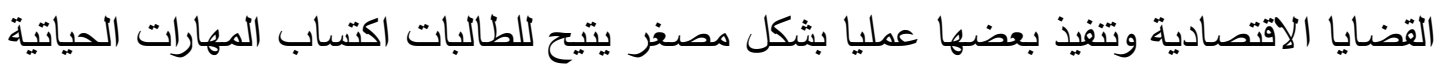

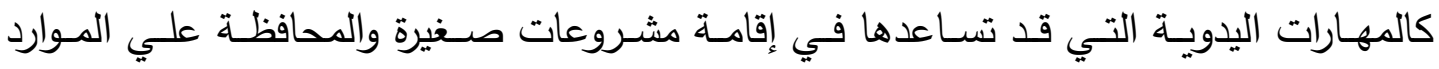
المتاحة، واتخاذ القرارات الأسرية الاقتصادية بشكل مدروس ومناسب فئه ،وأما قضايا البعد البيئي

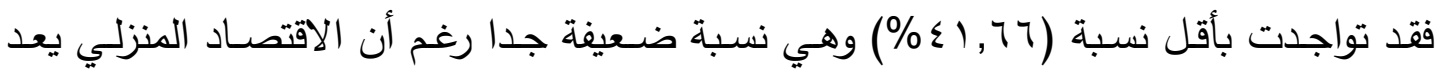

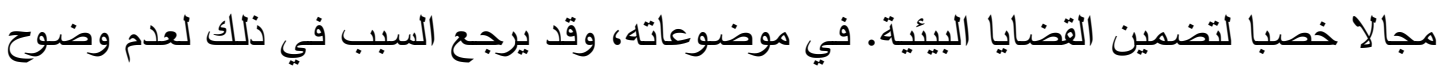

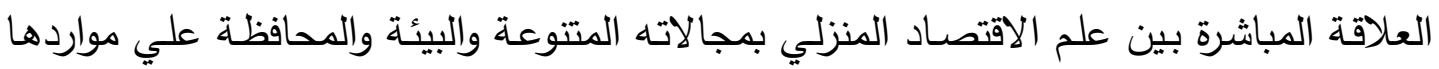
وحمايتها من التلوث والاستهلاك المستدام خاصة للموارد البيئية غير المتجددة.

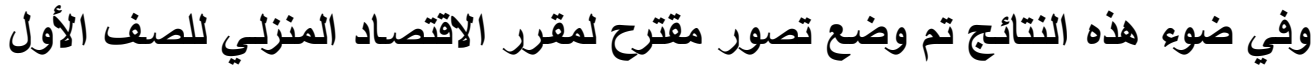

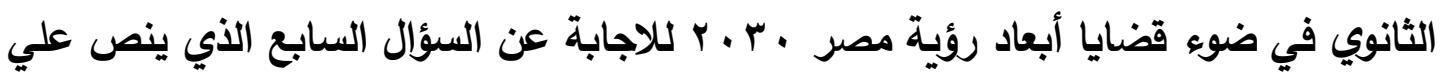

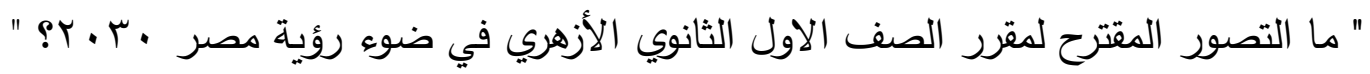

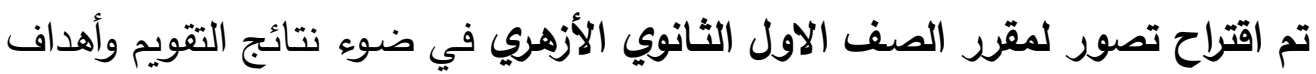
رؤية مصر • ·.r واهداف تدريس الاقتصاد المنزلي بالمرحلة الثانوية كما يلي: 
r- خصائص طالبات الصف الأول الثانوي واحتياجاتهن.

r- طبيعة مادة الاقتصاد المنزلي كمادة نظرية تطبيقية ترتبط بواقع المجتمع وقضاياه. ع - احتياجات المجتمع المصري في العصر الحالي لمواجهة التحديات والمتغيرات العالمية.

\section{أهداف التصور المقتر م:}

1- تضمين مقرر الاقتصـاد المنزلي للصف الأول الثانوي الأزهري لقضـايا رؤيـة مصـر

$$
\text { .r.T. }
$$

ץ- اكساب الطالبات المعارف والمهارات اللازمة لتحقيق أهداف التتمية المستدامة في شتي

$$
\text { مجالات حياتهن }
$$

r- اكسـاب الطالبـات المهـارات الحياتيـة اللازمـة لبنـاء شخصـياتهم وتعمير مجتمعـاتهم

$$
\text { كمهارات التثكير وحل المشكلات واتخاذ القرار • }
$$

ع- تعزيز القيم الأخلاقية والتأكيد علي التمسك بها في ظل أي متغيرات.

ه- تتمية القدرة علي العمل الجماعي والفردي واستحداث أفكار ابداعية من الموارد المتاحة. צ- تعظيم دور الأسرة في بناء الدتمع وتطويره وحل مشكلاته.

V- تتميـة التفكير الايجـابي والسمات الثخصـية التي تمكنهـه مـن مواكبـة التغيـرات وحل

$$
\text { المشكلات المختلفة }
$$

ᄉ- الوعي بأهمية المحافظة علي البيئة وحمايتها.

9- الوعي بضرورة استحداث فرص عمل ولو بسيطة كعمل مشروعات صغيرة

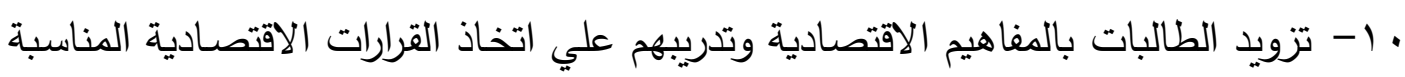
وتتمية الوعي الاقتصادي.

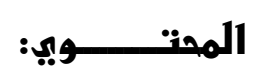

في ضوء الاهداف المقترحة يقدم البحث الحالي أمثلة للموضوعات ذات الصلة بقضايا

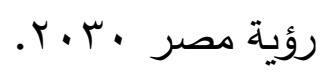


جدول (VIV) محتوي موضوعات التصور المقترح لمقرر الصف الأول الثانوي الأزهري في ضوء رؤية مصر •r.r.

\begin{tabular}{|c|c|c|c|}
\hline التطبيقات العملية & الموضوعات النظرية & الوحلة & اللدراسي الفصل \\
\hline 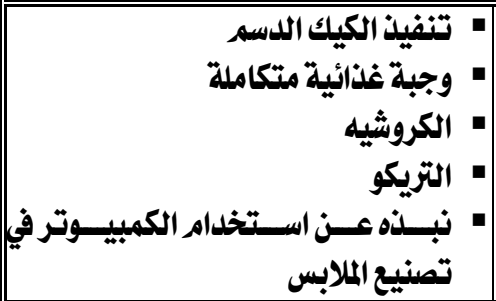 & 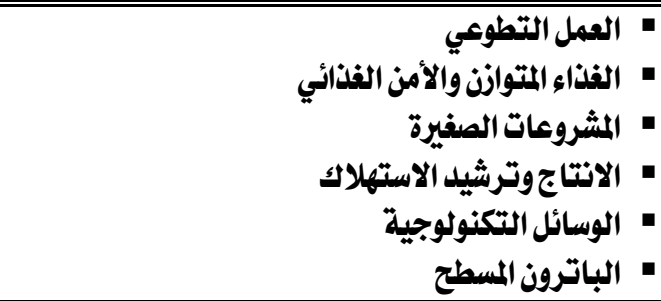 & نحوحياة & الأول \\
\hline 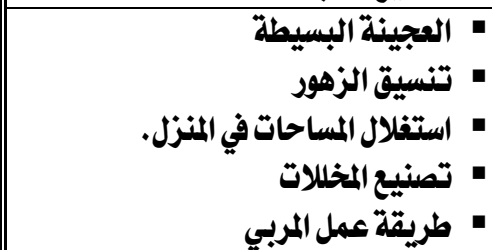 & 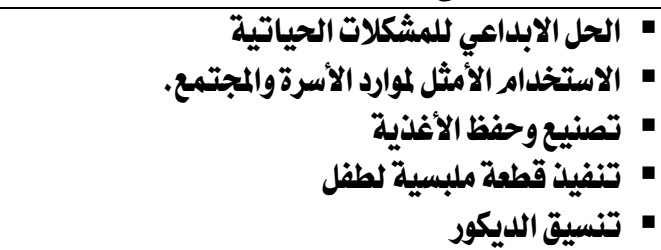 & |الأسرة قلب | المجتمع | & \\
\hline 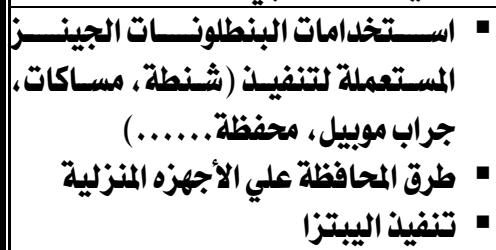 & 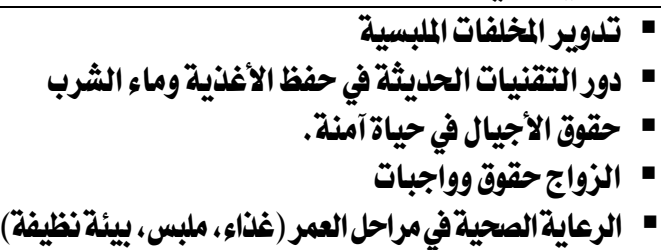 & بنفسك ابل & الثاني \\
\hline 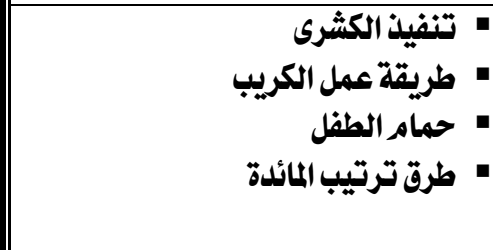 & 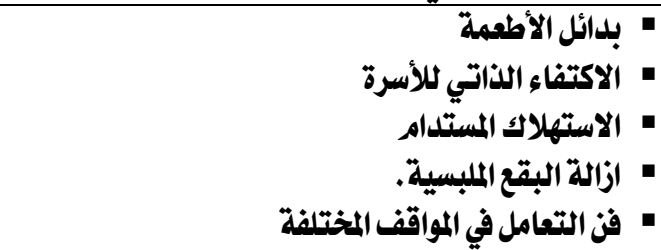 & أولادياة & \\
\hline
\end{tabular}

وتري الباحثة أن تنفيذ التصور المقترح لابد أن يكون باستخدام استراتيجيات وطرق

تدريس تعتمد علي جهد المتعلم كالطرق القائمة علي فلسفة التعلم النشط مثل:

• استراتيجية التعلم التعاوني في المعمل

$$
\text { • استراتيجية الاكتشاف الموجه }
$$$$
\text { المناقشة في مجموعات صغيرة }
$$$$
\text { - تمثيل الأدوار والنمذجة }
$$$$
\text { التعلم الذاتي والالكتروني المدمج }
$$$$
\text { البيان العملي والتجريب المعملي }
$$$$
\text { • المشروع وحل المشكلات الت }
$$

$$
\text { • الكرسي الساخن }
$$


بالإضافة للأنشطة الصفية واللاصفية والزيارات الميدانية والرحلات وورش العمل وكتابة

$$
\text { أستـارير الفردية والجماعية. }
$$

نظرا لطبيعة مادة الاقتصـاد المنزلي النظريـة التطبيقية ذات الطابع الفني تري الباحثة

$$
\begin{aligned}
& \text { تتويع أساليب التقويم وفقا للهدف منه ومن أبرزها: } \\
& \text { الاختبارات التحريرية والثفوية } \\
& \text { " تقويم الأداء } \\
& \text { الملاحظة } \\
& \text { ملفات الانجاز }
\end{aligned}
$$

في ضوء نتائج البحث يمكن تقديم التوصيات الآتية:

1- ضرورة مراعاة التوازن والتكامل بين محتوي كتاب الاقتصـاد المنزلي وتضمين قضـايا

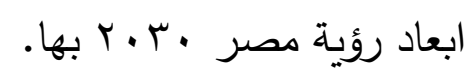

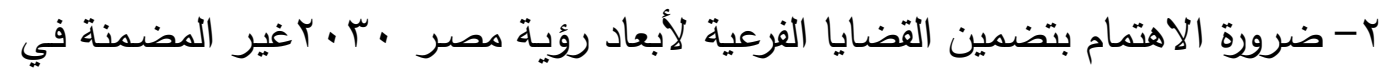

$$
\text { محتوي كتاب الاقتصاد المنزلي للصف الأول الثانوي الأزهري الحالي. }
$$

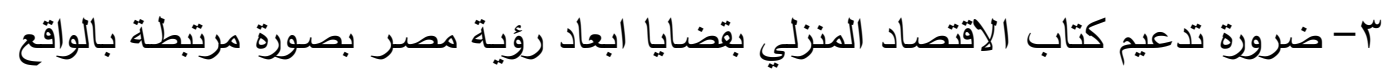

وأحداثه لجذب الطالبات وزيادة اهتمامهن بتطبيقها.

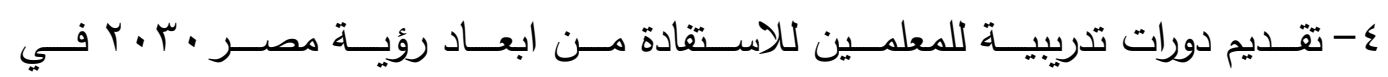

تخصصات مختلفة.

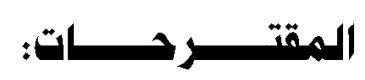

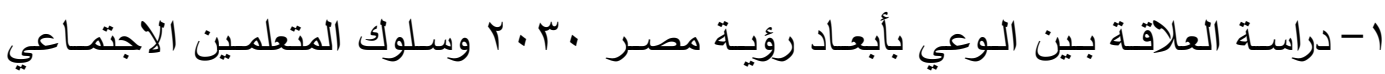

$$
\text { والاستهلاكي والبيئي. }
$$

r- تقويم محتوي كتب الاقتصاد المنزلي للمرحلة الاعدادية في ضوء رؤية مصر •r.r.r.

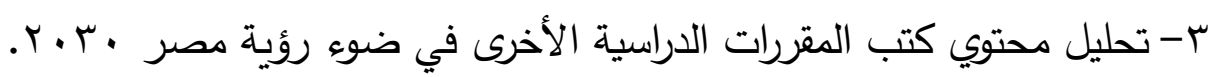

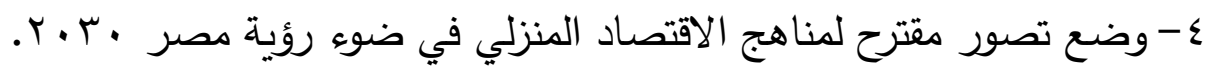




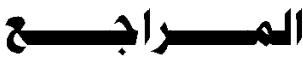

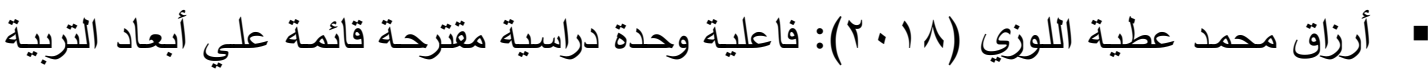

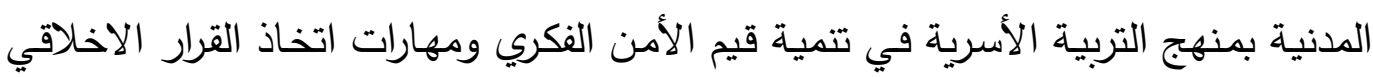

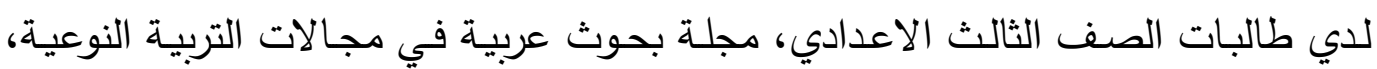

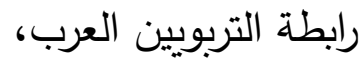

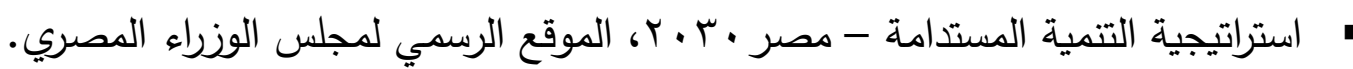

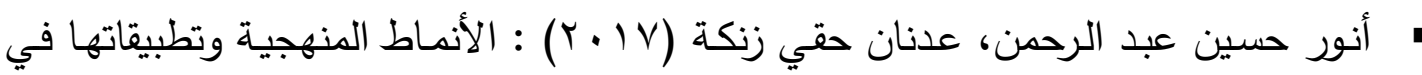
العلوم الانسانية والتطبيقية ،طس، مطابع شركة الوفاق للطباعة، بغداد.

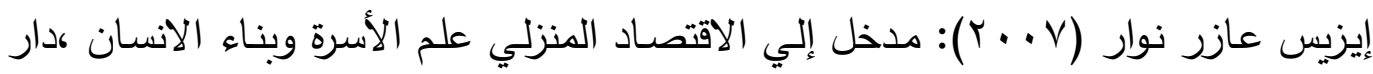
المعرفة الجامعية، الأسكندرية.

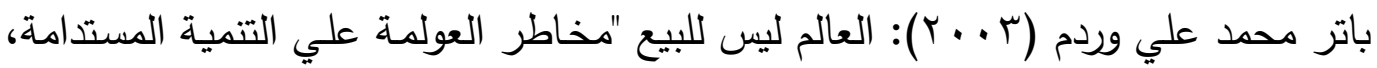

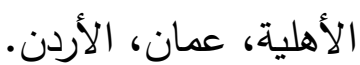
تغريد عبدالله عمران، عواطف لبني (؟ ( ـ ب) تلبية الاحتياجات التعليمية المرتبطة بالتتمية

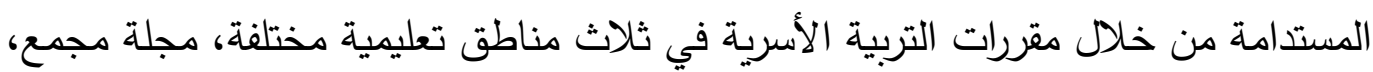

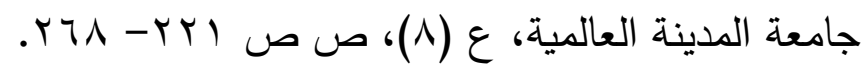

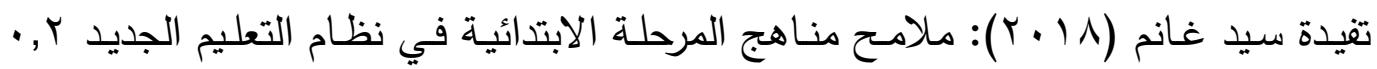

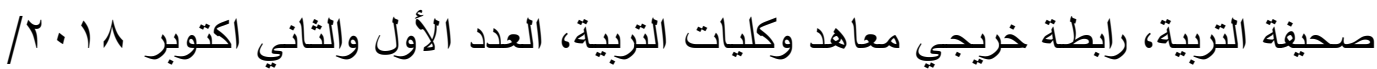

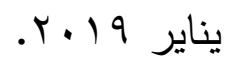

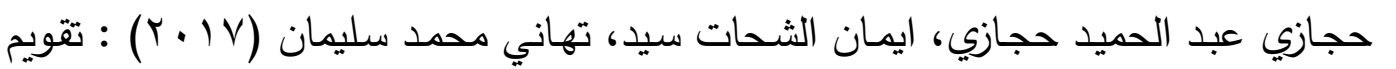

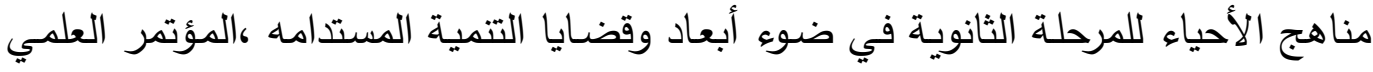
التاسع عشر، التربية العلمية والتتمية المستدامة، الجمعية المصرية للتربية العلمية، يوليو

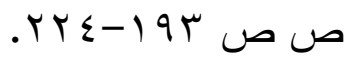

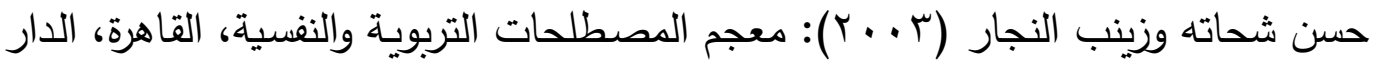
المصرية اللبنانية. دوجلاس موسشيت ( . . ب): منهاج متكامل للتمية المستدامة " مبادئ التتمية المستدامة"، ترجمة بهاء شاهين, الدار الدولية للاستثمارات الثقافية, القاهرة. 


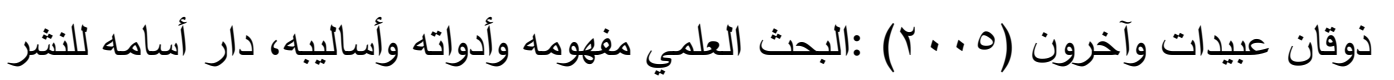
والتوزيع، الرياض.

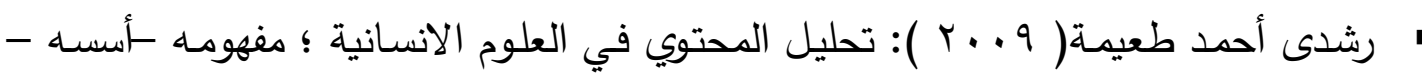
استخداماته، القاهرة، دار الفر العربي ،ط 9.

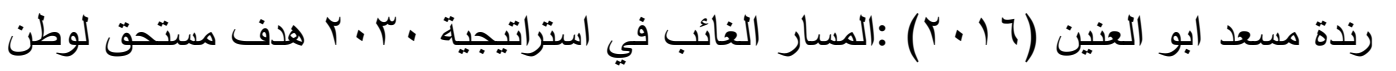

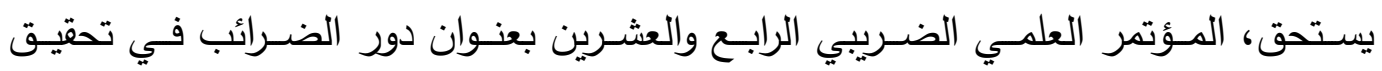

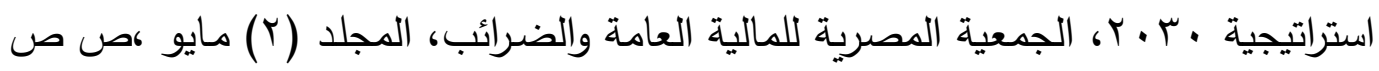
. $\{\leqslant-1$

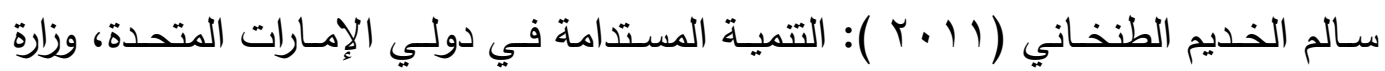

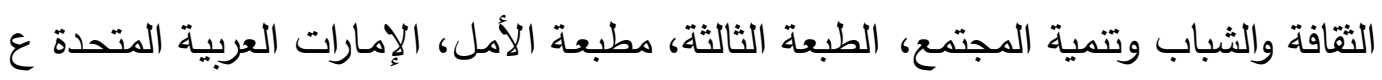

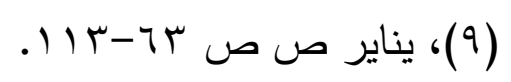

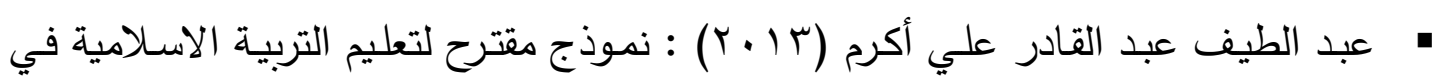

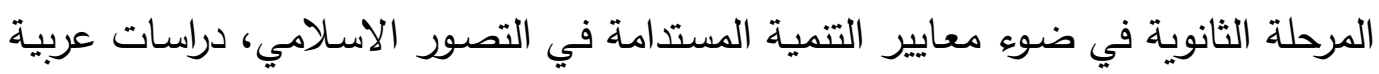

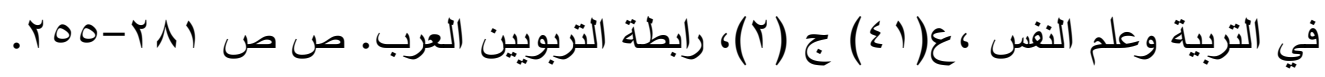

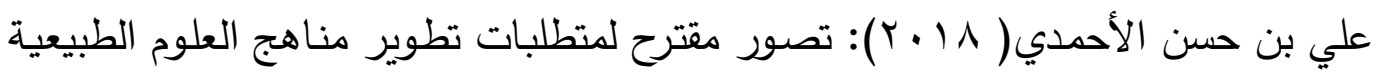

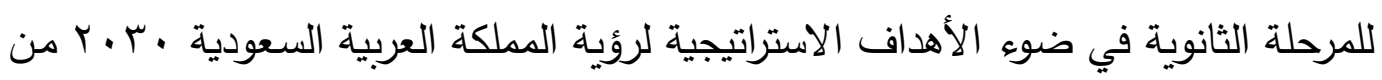

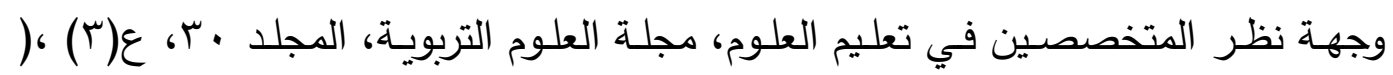

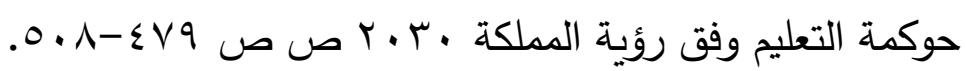

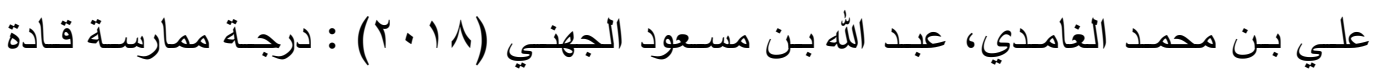
المـارس للكفايـات الفنيـة في ضـوه استراتيجية تطوير التعليم العـام في المملكـة العربيـة

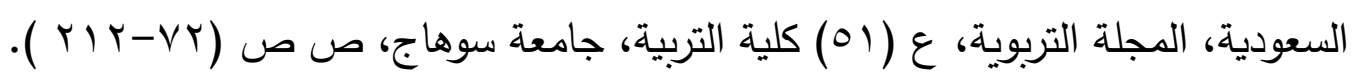

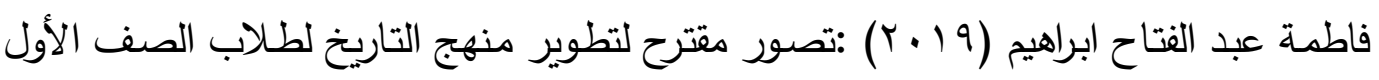

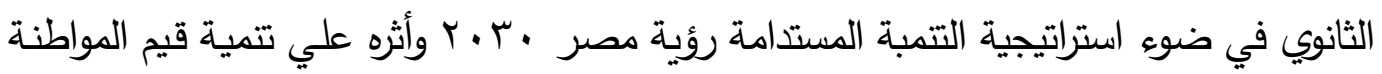

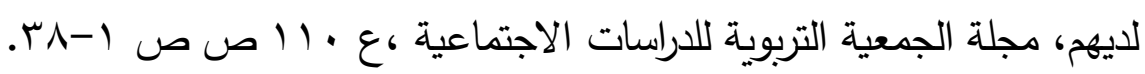
فؤاد سليمان قلادة (991 (19)): 


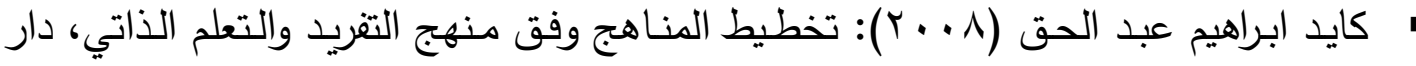

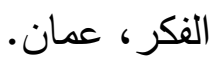

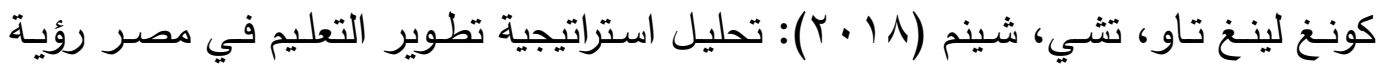

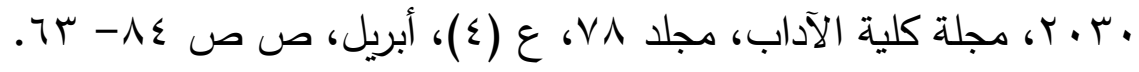

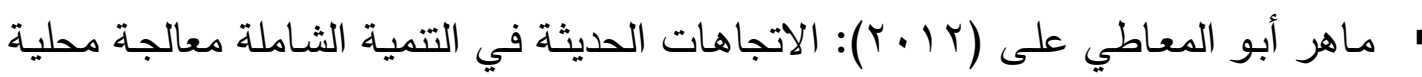

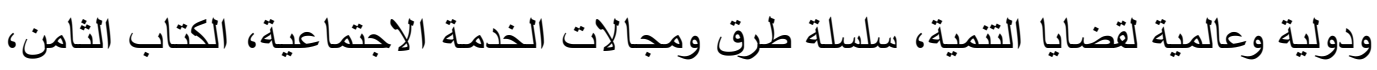
المكتب الجامعي الحديث، القاهرة.

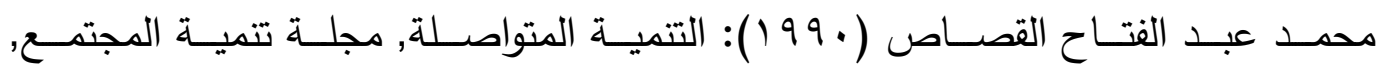

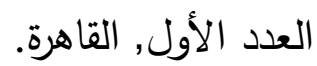

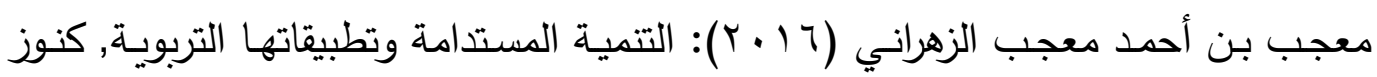

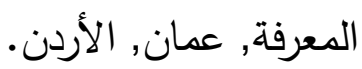
مندور عبد السـلام فتح الله (10 بـ ب): تحليل محتوي كتب العلوم (المفاهيم والتطبيقات)، الرياض، دار النشر الدولي.

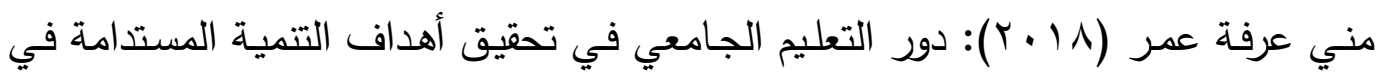

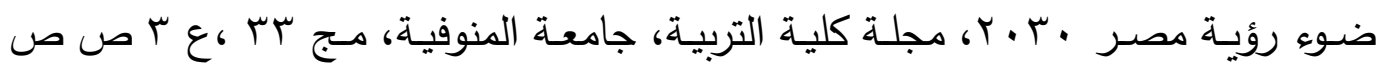
.ror-r).

مني مصطفي زيتون (9 ( ب): تصور مقترح لتطوير منـاهج التربية الموسيقية للمرحلـة

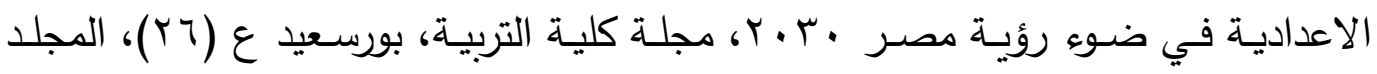

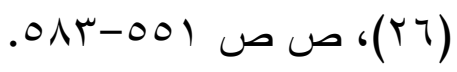

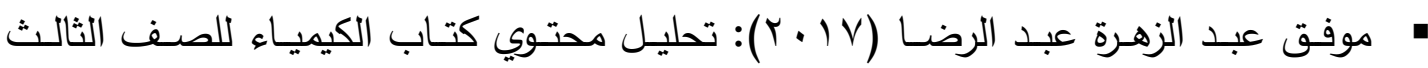

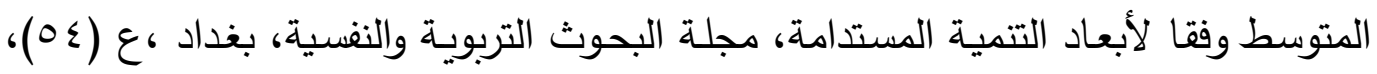

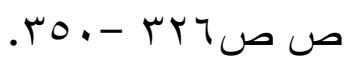
وثيقة رؤية مصر •r.r.r، الموقع الرسمي لمجلس الوزراء المصري.

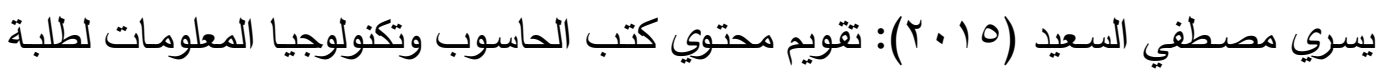
مراحل التعليم قبل الجامعي بصدر والسعودية والبحرين والكويت في ضوو المعايير العالمية

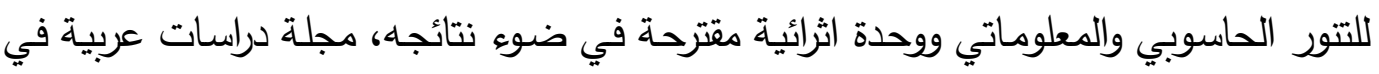

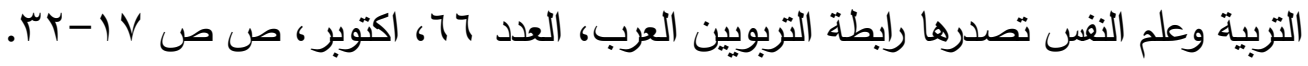


- Borg, C., Gericke, N., Hglund, H. O., \& Bergman, E. (2014). Subjectand experience-bound differences in teachers' conceptual understanding of sustainable development. Environmental Education Research, 20(4), 526-551.

- El-Megharbel, N. (2015). Sustainable development strategy: Egypt's vision 2030 and planning reform. Proceedings of Integrated Approaches to Sustainable Development Planning and Implementation, 27.

- Holsti, O. R., North, R. C., \& Brody, R. (1968). Perception and Action in the 1914 Crisis. Quantitative International Politics: Insights and Evidence, 123-158.

- Mayring, P. (2014). Qualitative content analysis: theoretical foundation, basic procedures and software solution.

- Ministry of Planning. (2015). Sustainable development strategy: Egypt's vision 2030.

- Neuendorf, K. A. (2016). The content analysis guidebook. sage.

- Vassiliou, M., \& Rowley, J. (2008). Progressing the definition of" ebook". Library Hi Tech, 26(3), 355.

- Wang, H. A. (1998). Science Textbook Studies Reanalysis: Teachers.

- Williams, D. (1983). Developing criteria for textbook evaluation. ELT journal, 37(3), 251-255. 